Universidade de São Paulo Instituto de Psicologia

Adriana Toyoda Takamatsu

\title{
Aloamamentação em cobaias Cavia porcellus
}

São Paulo 


\title{
Universidade de São Paulo
}

Instituto de Psicologia

Departamento de Psicologia Experimental

\section{Aloamamentação em cobaias Cavia porcellus}

\author{
Adriana Toyoda Takamatsu
}

Dissertação apresentada ao Instituto de Psicologia da Universidade de São Paulo como parte dos requisitos para obtenção do título de Mestre.

Área de concentração: Psicologia Experimental Orientador: César Ades

São Paulo

2007 
Autorizo a divulgação e reprodução total ou parcial deste trabalho, por qualquer meio convencional ou eletrônico, para fins de estudo e pesquisa, desde que citada a fonte.

Takamatsu, Adriana Toyoda.

Aloamamentação em cobaias Cavia porcellus / Adriana Toyoda Takamatsu; orientador César Ades - São Paulo, 2007, $116 \mathrm{p}$.

Dissertação (Mestrado - Programa de Pós-Graduação em Psicologia. Área de concentração: Psicologia Experimental). Instituto de Psicologia da Universidade de São Paulo.

1. Cobaias 2. Cuidado alomaterno 3. Aloamamentação 4. Filhotes precoces 5. Etologia I. Título. 
Adriana Toyoda Takamatsu

\section{Aloamamentação em cobaias Cavia porcellus}

Dissertação apresentada ao Instituto de Psicologia da Universidade de São Paulo como parte dos requisitos para obtenção do título de Mestre.

Área de concentração: Psicologia Experimental

Banca examinadora:

(Nome e assinatura)

(Nome e assinatura)

(Nome e assinatura)

Defesa de Mestrado realizada em

no Instituto de Psicologia da

Universidade de São Paulo, SP. 
Às minhas cobaias. 


\section{Agradecimentos}

Ao Professor César Ades, grande mestre e amigo, que soube ouvir e encorajar nos momentos mais difíceis. Obrigada pelas inúmeras conversas descontraídas e bate-papos que sempre deram uma energia positiva. Enfim, por tudo.

À Suemi, obrigada pelo carinho, broncas construtivas, dicas, inúmeras revisões do projeto, companheirismo, e principalmente pelo apoio e confiança de sempre.

À Nina, pela amizade e inúmeras e looongas conversas sobre cobaias e preás. E às nossas várias aventuras pela psico, quando algum preá fujão ou alguma cobaia perdida entrava pelos jardins e nos fazia correr como loucas, levantando pedras, fuçando em buracos, e os pequenos jardins transformavam-se em verdadeiras selvas!

À Pati Handa, Angélica e Dani, obrigada pela amizade, companhia e altos bate-papos. Enfim, obrigada pelo apoio de sempre.

À Carine, pela grande ajuda com a análise dos dados.

Aos grandes amigos Daisy e Anselmo, pela amizade e apoio incondicional, desde os tempos de psico. Obrigada por me ouvirem as alegrias e desabafos sobre o projeto e questões existenciais. Ao Anselmo, obrigada pela grande ajuda com a captura das imagens de vídeo; à Daisy, obrigada pela paciência incansável. Aos dois, por me acolher tão carinhosamente em sua casa na fase final de redação da dissertação; à Nenêm e Mila, duas gatinhas lindas, por me fazerem companhia e por me distraírem quando as coisas estavam muito sérias.

Agradeço a meus pais, Kazuite e Akiko, pela oportunidade de aprender; a meus irmãos, Marcos e Renata, por me ajudarem com cadernos, livros, cds e anotações, que eu sempre esquecia em algum lugar e vocês sempre davam um jeito de me entregar, onde quer que eu estivesse. À minha família: Tia Toyoko, Tio Elso, Dudu, Andrei, Tia Sigueko e Tio Chicão, por me ajudarem e apoiarem desde o 
começo. Agradeço a todos pelo suporte e paciência, cada um à sua maneira, durante todos estes anos.

À Kiki, minha pequena gerbil, que deixou grandes lembranças e muitas saudades.

Ao Chumbinho, meu cãozinho fiel.

À Fundação Parque Zoológico de São Paulo, por tornar possível a realização da primeira etapa deste projeto. Aos funcionários do Biotério do Zoológico de São Paulo pelo apoio e manutenção dos animais, sem os quais esta pesquisa não teria sido possível.

À FAPESP, pela bolsa concedida. 
Takamatsu, A. T. 2007. Aloamamentação em cobaias Cavia porcellus. São Paulo. Dissertação de Mestrado, Instituto de Psicologia, Universidade de São Paulo, São Paulo.

\section{Resumo}

A aloamamentação parece desafiar o princípio geral de que o cuidado materno deve restringir-se à própria prole. Embora a aloamamentação em cobaias domésticas Cavia porcellus - espécie em que um macho dominante pode reproduzir-se com várias fêmeas em um sistema de harém e em que os filhotes são precoces e capazes de ingerir alimentos sólidos logodepois do nascimento - já tenha sido observada, não foi submetida até o momento a um estudo sistemático. Na presente pesquisa, realizada com cobaias comuns (Etapa 1) e cobaias albinas (Etapa 2), buscamos descrever os aspectos básicos da interação fêmea-filhote ao longo das primeiras quatro semanas de vida dos filhotes, comparando a freqüência e a duração da amamentação de fêmeas mantidas sozinhas com a sua ninhada (Condição FS, 20 fêmeas) à de fêmeas pareadas quando as ninhadas tinham no máximo 3 dias de diferença (Condição FP, 19 pares de fêmeas), uma condição em que pode surgir aloamamentação. Verificou-se que, apesar da existência de apego em relação à mãe (os filhotes na condição FP permaneciam próximos à mãe e mamaram mais dela do que da fêmea alheia), aproximadamente $60 \%$ dos filhotes alomamaram. A aloamamentação, que se concentrou na primeira semana de vida com um decréscimo marcado em seguida e que não era sempre recíproca, decorreu basicamente da iniciativa dos filhotes. Os resultados não apóiam a hipótese funcional da aloamamentação enquanto competição entre os filhotes por um superávit de alimentação, mas indicam que constitui uma estratégia oportunista dos filhotes, propiciada pelas características da organização social das cobaias. 
Takamatsu, A. T. 2007. Aloamamentação em cobaias Cavia porcellus. São Paulo. Dissertação de Mestrado, Instituto de Psicologia, Universidade de São Paulo, São Paulo.

\section{Abstract}

Allosuckling in domestic guinea pigs Cavia porcellus

Allosuckling seems to challenge the general principle according to which maternal care should be retricted to offspring. While already reported, allosuckling in domestic guinea pigs Cavia porcellus - a species in which males may breed with several females, in a harem system, and in which pups are precocious and able to ingest solid food shortly after birth - has not been, to now, systematically described. The aim of the present research, performed with common guinea pigs (Phase 1) and albino guinea pigs (Phase 2) was to describe female-pups interactions throughout development, and to compare such interactions in isolated females with their litter (FS condition, 20 females) and in paired females with their litter (FP condition, 19 pairs), a condition in which allosucking performance is likely to happen. In spite of pups' attachment to their mothers (in condition FS, pups remained nearer to their mother than to the other lactating female and had longer and more frequent nursing episodes with her), allosuckling was relatively frequent (approximately $60 \%$ of pups were allonursed). Allosuckling peak occurred during the first week of life and markedly decreased thereafter, being mainly under the control of pups. Results do not favor a functional explanation of allosuckling as a competitive strategy of pups for a surplus of food, but suggest it is an opportunistic strategy which is made possible by the specific nature of guinea pigs social organization. 


\section{Índice}

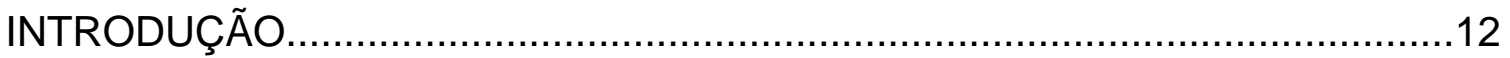

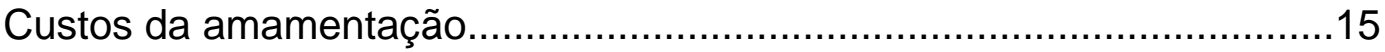

Formas de aloamamentação.................................................................17

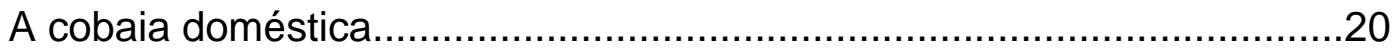

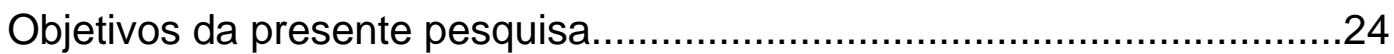

MÉTODO

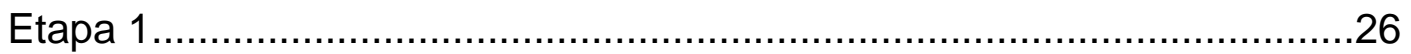

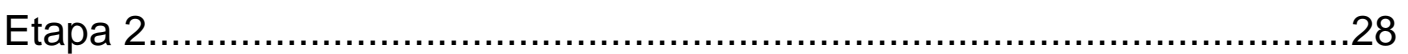

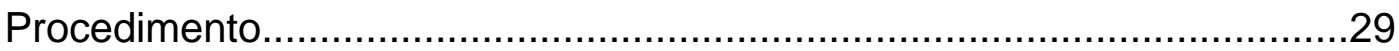

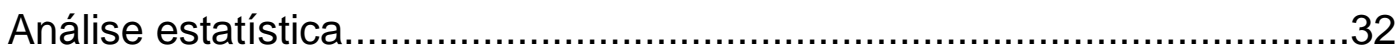

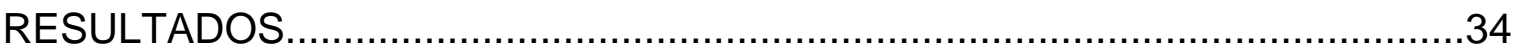

Observação qualitativa do comportamento no contexto de pareamento....35

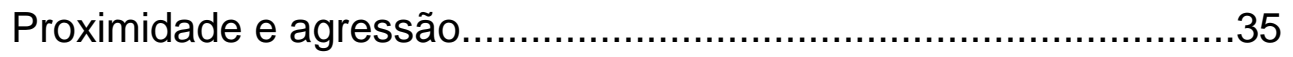

Iniciação do episódio de amamentação...........................................37

Posturas e comportamentos de amamentação.................................38

A terminação da amamentação......................................................39

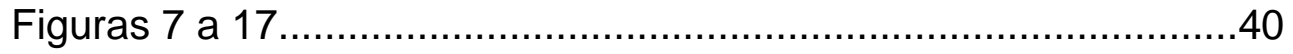

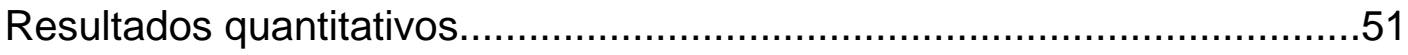

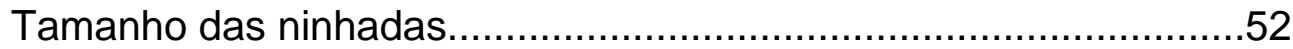

Ocorrência de aloamamentação....................................................52

Freqüência de filhotes que mamaram e alomamaram.....................53

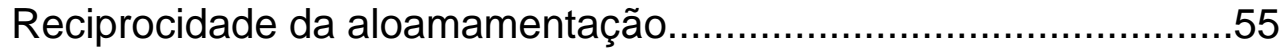

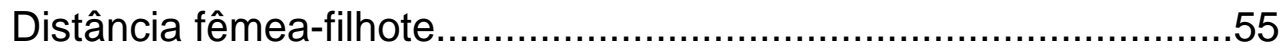

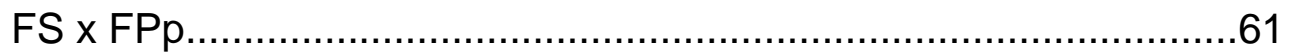


$\mathrm{FPp} \times \mathrm{FP}(\mathrm{p}+\mathrm{a})$ .65

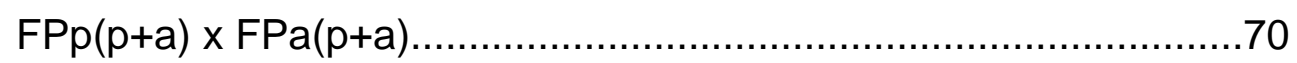

Mudanças ontogenéticas no peso dos filhotes................................75

Peso das fêmeas na primeira semana da Etapa 2.........................78

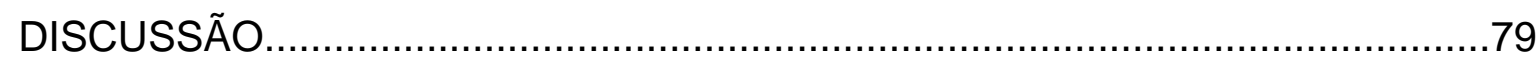

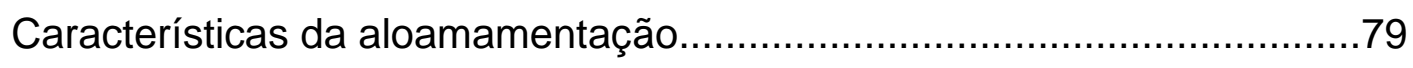

A aloamamentação como característica típica do

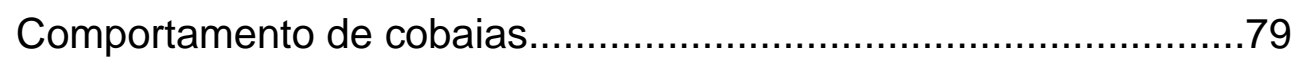

A manutenção da proximidade como processo básico......................81

Mudanças ontogenéticas na amamentação.....................................81

Uma janela temporal para a aloamamentação..................................83

O desenvolvimento ontogenético da aloamamentação.....................83

O controle da ocorrência e duração das amamentações

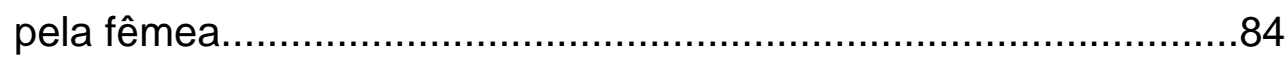

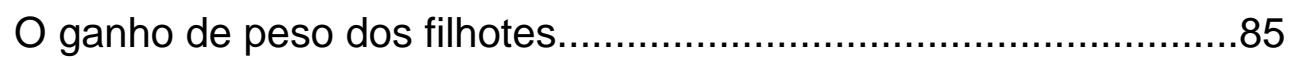

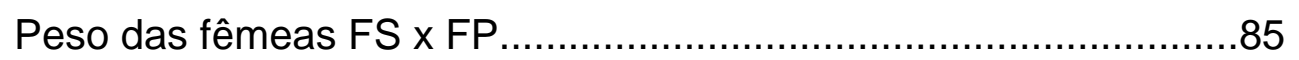

Diferenças entre cobaias comuns e albinas.....................................86

Funções possíveis da aloamamentação em cobaias.................................86

Hipóteses para a explicação da aloamamentação em

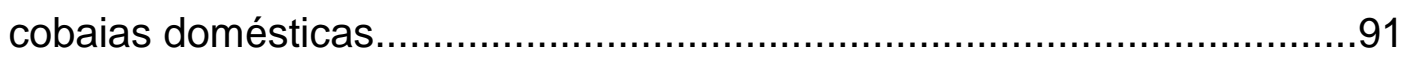

A hipótese da competição por um superávit alimentar..........92

A hipótese da amamentação oportunista...............................95

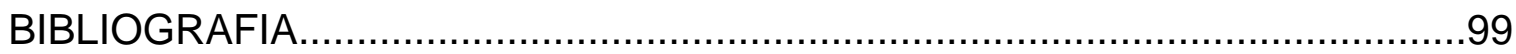

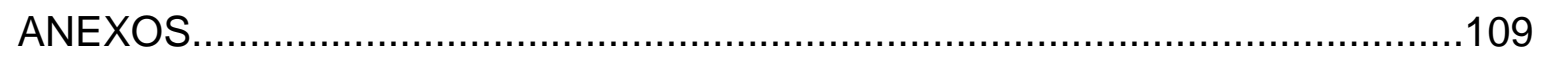




\section{INTRODUÇÃO}

A questão do cuidado aloparental, isto é, do cuidado de filhotes por indivíduos que não são seus progenitores, é surpreendentemente complexa e parece inconsistente com a teoria evolutiva clássica (Riedman, 1982).

A maioria dos casos de alocuidado e adoção foram registrados em mamíferos e pássaros, nos quais os sistemas de cuidado parental são particularmente bem desenvolvidos. O cuidado aloparental, ou comunal, tem sido freqüentemente registrado em (1) grupos relativamente pequenos e fechados, caracterizados por um alto grau de parentesco, (2) grupos familiares nos quais os jovens permanecem com seus pais por um ou dois anos após o desmame ou após atingirem a maturidade reprodutiva, e (3) grupos altamente sociais e cooperativos nos quais os indivíduos são freqüentemente relacionados geneticamente. Condições ambientais severas ou imprevisíveis parecem mediar a ocorrência de sistemas parentais que incorporam o cuidado comunal: (1) presas de grande porte e fontes de alimento isoladas ou imprevisíveis, nas quais são necessárias estratégias cooperativas de grupos de forrageio e (2) recursos limitados para reprodução. Neste último caso, o alocuidado pode ser a estratégia reprodutiva mais bem sucedida para indivíduos jovens, se não a única opção reprodutiva a eles disponível em decorrência da saturação do habitat. Reprodutores jovens podem não ser capazes de competir com adultos experientes em conseguir parceiros, espaço, e fontes de alimento (Riedman, 1982).

A vida em grupo talvez seja um pré-requisito para que fêmeas ajudem outras a criar seus filhotes (König, 1997), aumentando assim a proteção contra predadores 
(defesa cooperativa); promovendo melhor defesa de território e melhores locais de forrageio (caça cooperativa - Galef, 1991); favorecendo o efeito de diluição (probabilidade de um indivíduo ser pego durante um ataque diminui - Grinnell \& McComb, 1996); gerando maior proteção contra condições ambientais desfavoráveis (McShea, 1990) e melhor proteção contra ectoparasitas devido à limpeza social (Russell, 1985 em König, 1997). Ainda assim, viver em grupo acarreta custos: como uma maior competição por alimentos; competição por locais de reprodução e por parceiros (van Schaik e van Noordwijk, 1986); maior probabilidade de infecção com parasitas e doenças; maior visibilidade do ponto de vista dos predadores (Jarman, 1974) e custos de vigilância (Maestripieri, 1993). No entanto, o fato de muitos mamíferos viverem em grupo implica que nestes casos os benefícios são maiores que os custos (Lewin, 1987).

König (1997) define cuidado cooperativo como "uma situação na qual indivíduos adultos além dos pais biológicos auxiliam regularmente no cuidado dos filhotes" (para outras revisões ver: Riedman, 1982; Packer et al., 1992 e Roulin, 2002). As razões evolutivas para que fêmeas não-reprodutivas cuidem de filhotes alheios não precisam ser necessariamente as mesmas que regulam a cooperação entre fêmeas reprodutivas (König, 1997).

König (1994) observou em laboratório que fêmeas de camundongos Mus musculus domesticus irmãs-familiares obtinham maior sucesso reprodutivo (desmamavam mais filhotes) do que fêmeas em outras condições. Por outro lado, Hayes (2000) argumenta que nestas condições de laboratório - nas quais a maioria dos estudos com roedores foram feitos - o alimento é ilimitado e de fácil acesso, o que pode reduzir o custo do compartilhamento de leite. Hayes (2000) vai mais adiante e sugere que os resultados de König (1994) foram provavelmente artefatos de laboratório e que não seriam observados sob condições ambientais menos do que ótimas.

É muito disseminada a idéia de que os alocuidadores, tanto indivíduos nãoreprodutivos quanto os reprodutivos, cuidam de filhotes alheios porque estes thes são aparentados em algum grau; deste modo, direta ou indiretamente, os alocuidadores estariam se beneficiando através do aumento da aptidão abrangente. Esta questão foi analisada por Clutton-Brock (2002) e ele argumenta que vários estudos em aves e mamíferos cooperativos mostram que os ajudantes podem não 
ser aparentados aos filhotes que ajudam a cuidar e que estes ajudantes (nãoaparentados) investem tão arduamente quanto os parentes próximos. O autor aponta para uma subestimação dos benefícios indiretos do comportamento cooperativo e uma provável superestimação dos benefícios diretos do ato de ajudar.

Vários estudos verificaram a existência de diversas formas de cuidado alomaterno: comportamentos de "tia", "baby-sitting" e "brincar de mãe" em colobinos (McKenna, 1979); defesa de filhotes alheios em veados Odocoileus hemionus (Lingle et al., 2007); proteção contra predadores e limpeza social em coatis Nasua narica (Russell, 1983); carregamento de irmãos mais novos em gerbilos Meriones unguiculatus (Clark \& Galef, 2000) e em bugios Alouatta guariba (Miranda et al., 2005); vigilância e proteção em micos-de-cheiro Saimiri oerstedi (Boinski, 1987); escolta de filhotes por fêmeas em golfinhos Tursiops truncatus (Mann \& Smuts, 1998); alimentação de filhotes alheios em pinguins reis Aptenodytes patagonicus (Lecomte et al., 2006) e em pegas Cyanopica cyanus (Valencia et al., 2006); aloamamentação em elefantes africanos Loxodonta africana (Lee, 1987); cervos Dama dama (Birgersson et al., 1991; Ekvall, 1998); cervos vermelhos Cervus elaphus (Bartos et al., 2001); búfalos Bubalus bubalis (Murphey et al., 1991; Murphey et al., 1995; Paranhos da Costa et al., 2000); capivaras Hydrochaeris hydrochoerus (Nogueira et al., 2000); galea Galea musteloides (Künkele \& Hoeck, 1995); preás Cavia aperea (Monticelli \& Ades, 2003); cobaias Cavia porcellus (Takamatsu et al., 2003 e 2005); cães da pradaria Microtus ochrogaster (Hayes \& Solomon, 2006 e 2007); degus Octodon degus (Ebensperger et al., 2002, 2006 e 2007); macacos-prego Cebus olivaceus (O’Brien \& Robinson, 1991); camundongos Mus musculus domesticus (König, 1993 e 1994); focas Arctocephalus gazella (Hoffman \& Amos, 2005); vacas Bos taurus (Víchová \& Bartos, 2005); leões marinhos Eumetopias jubatus (Porter \& Trites, 2004), etc.

A existência de cuidado alomaterno aumenta as chances de um filhote órfão ser adotado. Aparentemente não só o filhote se beneficia, pois alomães jovens adquirem habilidades maternas (Roulin, 2002) ao manejar e transportar filhotes recém-nascidos. É possível também que a atração natural por filhotes e os laços sociais entre fêmeas alomães contribuam para a coesão e estabilidade do grupo.

Um alocuidado particularmente intrigante é a aloamamentação, que é encontrada em aproximadamente 68 espécies de mamíferos (Roulin, 2002). Dado o 
custo do leite, pode parecer estranho que fêmeas, em várias espécies, amamentem filhotes alheios. Existe uma série de possíveis razões adaptativas que justificam este uso "altruísta" do leite que, de qualquer maneira, não pode ser tão intenso a ponto de prejudicar a alimentação dos próprios filhotes. Vários estudos comprovam que a aloamamentação nunca é maior do que a amamentação (Birgersson et al., 1995; Ekvall, 1998; Murphey et al., 1995; Lee, 1987).

\section{Custos da amamentação}

A maternidade é uma condição custosa e extenuante para todas as fêmeas de mamíferos. A reprodução da fêmea é dividida em gestação, lactação, e retomada do ciclo sexual (Fedigan \& Rose, 1995), e todas estas etapas custam tempo e energia. O custo energético da lactação é inquestionável, surgindo da conversão dos nutrientes maternos ou reservas corporais em leite. A energia do leite está relacionada à massa corporal da mãe (Oftedal, 1984). Apesar da conversão das reservas ou consumo energético materno parecer eficiente (em torno de uma taxa de 80\%) (Prentice \& Whitehead, 1987), a maioria das mães mamíferas ainda precisa aumentar seu consumo de energia de duas a cinco vezes acima dos níveis normais (Clutton-Brock, 1991; Sikes, 1995) para manter o crescimento do filhote.

Algumas das diferenças entre espécies no custo de transferência de energia da mãe para o filhote estão relacionadas à capacidade materna de armazenar energia antes da gestação, através das reservas de gordura corporal e da qualidade de suas dietas antes e durante a lactação (Lee, 1997). A duração da lactação também é ambientalmente sensível: a lactação prolongada pode ocorrer como resultado de uma baixa aquisição energética ou do alto gasto energético em ambientes de qualidade pobre (Lee, 1997). Assim, uma variedade de fatores pode limitar o sucesso reprodutivo de fêmeas mamíferas: abrigo adequado, falta de nutrientes específicos, ou até mesmo a disponibilidade de água para a produção de leite. Porém, o aumento de consumo de comida não é sempre suficiente para compensar as demandas corporais durante a primeira fase da lactação e no pico da lactação, o que leva a fêmea lactante a mobilizar suas reservas de gordura, proteína e minerais (Vernon e Flint, 1984). 
Fêmeas cobaias armazenam parte relativa da grande quantidade de ingestão energética durante os dias 30-55 de gestação na forma de gordura, para ser usada durante as duas últimas semanas de gestação, época em que sua mobilidade física fica limitada e sua necessidade energética é maior (Künkele, 2000b). Millar (1978) observou que fêmeas de camundongos Peromyscus leucopus devem se comprometer a um tamanho particular de ninhada muito antes do período de pico de demanda energética: a fêmea não tem como prever as condições ambientais que virão. Uma estratégia que envolve um comprometimento inicial a tantos filhotes quanto poderiam ser sustentados em condições ideais permitiria o máximo sucesso reprodutivo em condições favoráveis, com a opção de ajustar a posteriori o tamanho da ninhada através de canibalismo (ou até mesmo do abandono de toda a ninhada) se as condições não forem favoráveis durante a lactação.

Entre espécies que dão luz a ninhadas, o tamanho da ninhada afeta o crescimento dos filhotes. Membros de ninhadas pequenas tendem a apresentar acelerado crescimento e desmame precoce. Gravidez e restrição de comida durante a lactação estão associadas ao desmame precoce e crescimento lento do filhote, sugerindo uma franca troca materna entre a reprodução atual e futura que não é influenciada pelas demandas do filhote. Alimentos pobres durante o período que antecede a lactação ou durante a gestação, assim como pouco consumo de energia durante a lactação, todos estes fatores reduzem a condição materna, a massa e a composição corporal (Lee, 1997). Em ovelhas, Ovis aries, foi observado que fêmeas nascidas em anos pobres podem perder um ano de reprodução, porque elas alcançam a massa corporal crítica um ano mais tarde (Steinheim et al., 2002).

Apesar de ser a mãe quem determina, em sua maior parte, a estratégia de investimento, os filhotes determinam alguns de seus aspectos. A estratégia de lactação pode ser, por exemplo, alterada de acordo com o sexo dos filhotes: filhotes machos tendem a apresentar altas demandas metabólicas e a crescer mais rapidamente do que os filhotes fêmeas (Clutton-Brock et al., 1985). A mãe precisa balancear as necessidades de crescimento e sobrevivência de seu filhote às custas de sua própria condição física e futura habilidade de reprodução.

As mudanças no comportamento materno mostram-se sincronizadas com o desenvolvimento dos filhotes, existindo um feedback na relação mãe-filhote que regula a quantidade de comportamento materno apresentado (Brown, 1998). 
comportamento materno não pode ser considerado em separado do comportamento filial, por causa de uma sempre presente regulação recíproca (Bussab, 1998). O desenvolvimento do comportamento da mãe e dos filhotes ocorre dentro de interações recíprocas e sincronizadas. As condições hormonais necessárias para a gravidez e parto, sempre disponíveis para as mães, são usadas para a constituição de um estado comportamental de cuidado e atração pelo filhote. O calor do corpo materno com um odor particular está sempre disponível para mamíferos neonatos. Estes estímulos são usados na produção de muitos comportamentos do neonato, inclusive aqueles usados para manter contato com a mãe, mamar da mãe, e obter nutrientes dela (Moore, 2007).

O forte apego ao cuidador é crítico para a sobrevivência em espécies altriciais, incluindo humanos. O sistema de apego evoluiu para assegurar que animais altriciais facilmente formassem um repertório comportamental de proximidade e procura pelo cuidador primário, sem importar a qualidade de cuidado recebido. Em ratos adultos, a emergência funcional do locus coeruleus e da amígdala correlacionam-se ao término do período sensível de estampagem: o cérebro do filhote recém-nascido não é uma versão imatura do cérebro do adulto, mas é constituído para otimizar o apego ao cuidador (Moriceau \& Sullivan, 2005).

\section{Formas de aloamamentação}

Em macacos-prego Cebus olivaceus (O’Brien \& Robinson, 1991) 0 parentesco é a mais consistente influência no comportamento alomaterno. Irmãos interagiram com filhotes quase quatro vezes mais freqüentemente do que parentes distantes e não-parentes. Irmãos se envolviam mais em associações com o filhote e o carregava mais; estas interações permitiam que a mãe tivesse mais tempo para outras atividades (forragear). Os comportamentos de carregar e de associação são as interações alomaternas mais comuns e mais importantes porque os filhotes precisam ser carregados até tornarem-se independentes e requerem monitoramento à medida em que tornam-se auto-suficientes. A aloamamentação foi um comportamento não freqüente comparado aos outros, envolvendo somente a fêmea lactante, e não foi influenciada pela posição hierárquica ou parentesco. Os filhotes mamaram de fêmeas não-aparentadas e de fêmeas de alto e baixo nível hierárquico. As fêmeas facilitavam as interações de aloamamentação levantando o braço e 
expondo a mama, como faziam quando seu próprio filhote se aproximava para mamar. Os autores sugerem que o custo da aloamamentação é compensado pela expectativa de reciprocidade de outras fêmeas. A reciprocidade explicaria por que a aloamamentação independe da posição hierárquica e parentesco, e inclui fêmeas grávidas e fêmeas que recentemente perderam seus filhotes.

Em cervos, Birgesson et al. (1991) e Ekvall (1998) relatam que uma situação típica de aloamamentação ocorria quando um filhote estava mamando em sua própria mãe e outros filhotes corriam e tentavam mamar nas outras três tetas restantes. A fêmea freqüentemente inspecionava os filhotes que se aproximavam do mesmo modo que fazia com o filhote próprio, e a aloamamentação só ocorria quando o filhote próprio estava mamando. Os filhotes pareceram aprender gradualmente a discriminar as fêmeas que eram mais receptivas (Ekvall, 1998). Assim como em cervos, em búfalos Bubalus bubalis as fêmeas aceitavam filhotes alheios somente quando seus próprios filhotes já estavam mamando (Murphey et al., 1995); um caso de aloamamentação neste contexto foi observado em elefantes africanos Loxodonta africana (Lee, 1987).

Segundo Murphey et al. (1995), a mãe não é capaz de afastar os filhotes estranhos sem afastar o seu próprio. Em cervos, mães parecem capazes de impedir que filhotes alheios mamem: quando o filhote alheio mamava pelo lado oposto ao do filhote próprio a mãe era capaz de empurrar com a pata somente o filhote alheio; a aloamamentação, uma vez iniciada, aumentava rapidamente, provavelmente devido a uma combinação do desenvolvimento do filhote, aprendizagem e cópia social; o aumento da aloamamentação ao longo da lactação reflete a capacidade de o filhote em detectar episódios de amamentação, aumento de sua demanda nutricional e a capacidade de fêmeas mais velhas em aumentar a produção de leite no período final de lactação; de fato, filhotes que alomamaram cresceram mais rápido (Ekvall, 1998). No caso dos elefantes, Lee (1987) observou que fêmeas que receberam cuidado alomaterno quando eram filhotes ajudaram suas alomães a cuidarem de seus filhotes mais tarde; essa reciprocidade a longo-prazo contribui para estabelecer uma relação próxima entre filhotes e membros mais velhos dentro da unidade familiar, assegurando a estabilidade familiar. Em elefantes também foi constatado que a mortalidade de filhotes nos primeiros 24 meses de idade (período crítico de dependência e vulnerabilidade do filhote) foi maior em famílias sem alomães, e essa 
mortalidade declinou à medida que o número de alomães aumentava (Lee, 1987). Em todos os casos, a amamentação foi maior que a aloamamentação.

Um estudo com dois grupos de capivaras, Hydrochoerus hydrochaeris (Nogueira et al., 2000), mostrou que todas as fêmeas amamentaram todos os filhotes de seu grupo na mesma freqüência. Os dados sugerem que o cuidado alomaterno, no caso das capivaras, pode estar relacionado à posição hierárquica das mães e que possivelmente fêmeas subordinadas cuidam mais dos filhotes do que fêmeas dominantes.

Hayes \& Solomon (2006) observaram em filhotes de cães da pradaria Microtus ochrogaster que a condição em que há mais de uma fêmea reprodutiva aumentava duas formas de investimento parental, termorregulação e volume de leite, que contribuem para o maior ganho de peso dos filhotes.

Até o momento, o único estudo que diz claramente que fêmeas podem controlar a liberação de leite e sincronizar as mamadas com outras fêmeas de modo a evitar a aloamamentação, foi realizado em porcos Sus scrofa domestica por Illmann et al. (2005). Os autores propõem que a sincronização de episódios de amamentação (uma sobreposição temporal de episódios de amamentação de duas ou mais fêmeas) seja um mecanismo para reduzir a incidência de aloamamentação. Este mecanismo seria especialmente útil quando uma mãe não é capaz de identificar seus filhotes antes e/ou durante a amamentação, como pode ocorrer em mamíferos com grandes ninhadas, como no caso dos porcos. O Efeito da sincronização da amamentação na redução da aloamamentação deve ser maior em espécies que apresentam um tempo curto de liberação de leite e maiores intervalos entre os episódios de amamentação. Isto implica que se um filhote alheio tenta alomamar, eles correm o risco de perder completamente a amamentação sincronizada de sua própria mãe. Portanto, o custo de alomamar é alto durante as amamentações sincronizadas e os filhotes devem evitá-la. Uma fêmea de porco doméstico amamenta a cada 45 - 70 minutos, e cada amamentação dura cerca de 4 - 10 minutos, mas o verdadeiro consumo de leite ocorre somente durante a breve liberação de leite que se inicia de 1 - 4 minutos depois do início da amamentação e dura por somente 15 - 20 segundos. O tempo curto e bem definido de liberação de leite torna possível registrar se houve ou não transferência de leite durante a amamentação e quais filhotes participaram. Uma característica clara de 
amamentação com liberação de leite é o rápido aumento de vocalização do filhote 20 egundos antes da liberação de leite e os rápidos movimento de sucção da boca. Os autores verificaram que a sincronização de amamentação aumentou em resposta ao risco de aloamamentação; quanto menos amamentação sincronizada havia mais tentativas de aloamamentação; e amamentações menos sincronizadas terminavam mais freqüentemente sem liberação de leite. Os resultados sugerem que uma fêmea pode baixar a probabilidade de aloamamentação aumentando as amamentações sincronizadas e aumentando as amamentações não-nutritivas. No entanto, ela é incapaz de impedir completamente a aloamamentação.

Neste estudo, a maioria das amamentações foram altamente sincronizadas, 0 que significa que o tempo de intervalo entre as amamentações de fêmeas pareadas foi muito curto para permitir que um filhote conseguisse leite das duas fêmeas. A aloamamentação completa (com liberação de leite) foi observada em 17\% das amamentações observadas, o que comprova que as fêmeas foram incapazes de inibir completamente a aloamamentação. Entretanto, se compararmos a freqüência de aloamamentações completas (17\%) com a freqüência das tentativas de aloamamentação (36\% do total de amamentação), nota-se que as fêmeas foram capazes de diminuir a freqüência de aloamamentação completa pela metade, por não liberarem o leite (Ilmann et al., 2005).

\section{A cobaia doméstica}

O presente estudo retoma a questão do alocuidado, sob a forma de aloamamentação, em cobaias domésticas Cavia porcellus já abordada por Kunkel \& Kunkel (1964) e Fullerton et al. (1974) entre outros.

A cobaia doméstica Cavia porcellus é uma espécie exclusiva da América do Sul, tendo como possível ancestral selvagem o preá, Cavia aperea (Weir, 1974). O processo de domesticação do preá ocorreu nos Andes há 3000-6000 anos (Rood, 1972; Weir, 1974). Price (1984) descreveu para outras espécies domesticadas em relação às silvestres, que o repertório dos padrões comportamentais era similar, sem perda ou adição de elementos comportamentais, apenas mudanças nos limiares de exibição. A cobaia é menos agressiva do que o preá e possui maior plasticidade social, apresenta diminuição de respostas de fuga ou congelamento e menor 
reatividade a estímulos externos, além de exibir com maior freqüência comportamento de corte, quando comparada à espécie selvagem (King, 1956; Rood \& Weir, 1970; Rood, 1972; Weir, 1974). A cobaia é distintamente menos atenta a seu ambiente físico do que o preá. A atividade basal do sistema simpáticoadrenomedular e a reatividade deste mesmo sistema e do sistema pituitárioadrenocortical são reduzidos na cobaia doméstica. Assim, o processo de domesticação da cobaia doméstica levou a traços comportamentais típicos: agressividade reduzida e aumento da tolerância social. A diminuição da reatividade do organismo ao estresse pode ser devido aos mecanismos fisiológicos que auxiliam os animais domesticados a ajustarem-se às condições colocadas pelo homem (Künzl \& Sachser, 1999).

Furnari (2006) observou diferenças significativas entre pares intra e interespecíficos de cobaias Cavia porcellus e preás Cavia aperea: cobaias interagiram, cortejaram-se e exploraram-se mais do que preás, e preás se mostraram mais ativos e exploradores do meio. Os pares interespecíficos também diferiram significativamente entre si, de forma assimétrica: enquanto machos preás cortejaram fêmeas cobaias e copularam com estas (menos, contudo, do que no caso das fêmeas coespecíficas), machos cobaias praticamente não cortejaram fêmeas preás, provavelmente por causa dos altos níveis de agressão destas. Os resultados demonstraram a existência de barreiras comportamentais entre as duas espécies, devidas provavelmente à domesticação, e capazes de gerar um isolamento reprodutivo parcial.

King (1956) estudou cobaias domésticas em condições semi-naturais e observou que a periodicidade diária das cobaias é governada em grande medida pela temperatura e intensidade de luz solar. Durante o verão os animais eram mais ativos quando o sol estava baixo ou logo após o crepúsculo, e evitavam a luz intensa do meio-dia. Em dias nublados eram ativos ao longo do dia.

A cobaia vive em grupos caracterizados por uma estrutura de harém (Rood, 1972) e são animais altamente sociais. Machatschke et al. (2004) observaram que em cobaias (8 - 36 meses) o nível de ocitocina (que possui efeito anti-estressante) era menor em animais isolados do que nos animais que foram observados em pares, o que sustenta a sociabilidade destes animais. Tokumaru (1995) verificou que 
filhotes em condição de separação eram tranqüilizados (os comportamentos de 'aflição' foram suprimidos) quando um outro indivíduo era introduzido no mesmo ambiente, podendo ser até um desconhecido.

O macho atinge a puberdade por volta de 30-40 dias, enquanto que a fêmea torna-se madura entre 55-70 dias (Asdell, 1964). O ciclo estral varia entre 15 e 17 dias (Young, 1969); o estro é espontâneo e dura por aproximadamente 8 horas (Young et al., 1935). Na cobaia ocorre também um estro pós-parto (King, 1956) que se dá de minutos a algumas horas após o nascimento dos filhotes (Avery, 1925; Young, 1969).

A gestação dura cerca de dois meses, podendo nascer entre um e oito filhotes, apesar de a mãe só possuir duas tetas (Beisiegel, 1993). Os filhotes são precoces, nascendo já homeotérmicos, com o corpo coberto por pêlos, com olhos e ouvidos funcionais, capacidade para ingerir alimentos sólidos e de se locomover e interagir com outros indivíduos do grupo (Tokumaru, 1995). Mamam por cerca de 23 dias (Raffel et al., 1996 em Künkele e Trillmich, 1997).

Os filhotes de cobaia reconhecem suas mães (Niciporciukas et al., 1999; Jäckel \& Trillmich, 2003) e as mães reconhecem seus filhotes (Tokumaru, 2000; Porter et al., 1973). Niciporciukas et al. (1999) observaram que filhotes de cobaia discriminavam sua própria mãe de uma fêmea lactante não-familiar sem que houvesse contato direto e interação próxima, mas a discriminação só foi possível quando o filhote estava a curta distância, de fato, quando o filhote estava próximo à tela. Porter et al. (1973a) observaram que fêmeas cobaias passavam significativamente mais tempo perto de seus filhotes de 1-2 dias de vida do que perto de uma ninhada alheia de mesma idade; estas fêmeas apresentaram indicações comportamentais de reconhecimento e apego a seus próprios filhotes dentro de 48 horas após o nascimento. Este reconhecimento e um sistema de apego (Henessy, 2003) permitem que a ninhada permaneça próxima da mãe, mesmo durante o deslocamento. Wewers et al. (2003), em seu estudo com filhotes de cobaias de 13-14 dias de idade, observaram que quando separados de suas mães e colocados em um ambiente estranho, imediatamente após a separação somente suas próprias mães eram capazes de tranquilizá-los (usando-se como critério de tranqüilização, os níveis de cortisol dos filhotes), mas após 2 horas de separação a presença de outro animal tinha o mesmo efeito tranquilizador. 
Künkele (2000a) observou que mães cobaias alcançam até 50\% da produção total durante a gestação e que os efeitos relativos do tamanho da ninhada na produção total e seu custo energético (incremento do consumo de energia pelas mães) foram quase idênticos durante a gestação e a lactação. O incremento da ingestão energético por filhote decresceu dramaticamente com o aumento do tamanho da ninhada, e filhotes de ninhadas grandes obtiveram menos leite do que filhotes de ninhadas pequenas. Os filhotes de ninhadas grandes reagiram consumindo mais alimento sólido, porém, a taxa de crescimento e o peso corporal final de filhotes de diferentes tamanhos de ninhada indicam que o consumo de alimento sólido está longe de compensar totalmente a redução da ingestão de leite materno, pelo menos durante os 10 primeiros dias de vida. O autor levanta a hipótese de que a produção de leite da mãe cobaia parece ser ajustada pelo tamanho da ninhada que ela de fato deu à luz, sem muita capacidade de aumentar ou diminuir a produção de leite.

Esta hipótese foi confirmada por Laurien-Kehnen \& Trillmich (2003), que verificaram que mães cobaias não aumentam a produção de leite com o aumento da demanda dos filhotes. De fato, os autores verificaram que mães cobaias têm sua produção de leite ajustada para o tamanho de ninhada de que estava grávida. 0 longo período de gestação relativo à lactação, assim como a alta eficiência energética da produção materna durante a gestação permitem que as mães cobaias mantenham sua ingestão energética diária durante a gestação em um nível relativamente baixo e ainda assim alcançar 50\% da produção total (Künkele, 2000b).

Sabe-se que muitos roedores altriciais ajustam o tamanho da ninhada através do infanticídio durante a primeira fase da lactação (Perrigo, 1987). Esta opção não se aplica às mães cobaias, porque na época do nascimento o investimento materno está muito avançado e o tamanho da ninhada já terá afetado sua reprodução e seu custo energético significativamente (Künkele, 2000a). Um mecanismo mais adequado para ajustar o tamanho da ninhada é provavelmente a reabsorção fetal durante a gestação (Peaker \& Taylor, 1997). Além do mais, em contraste aos roedores altriciais, o tamanho da ninhada afeta muito a massa corporal das mães cobaias durante a gestação. Este fato deve ser ecologicamente relevante em termos de risco de predação de fêmeas grávidas. Se o aumento da massa corporal reduz suas chances de escapar de predadores, variáveis locais e sazonais na pressão de 
predação podem desempenhar um papel importante na decisão do tamanho da ninhada (Künkele, 2000a). O grande tamanho da ninhada da cobaia doméstica $C$. porcellus comparadas às ninhadas de preá $C$. aperea parece se uma característica selecionada pela domesticação; de acordo com Kasparian et al. (2005) o tamanho ótimo de ninhada de $C$. aperea é de dois filhotes. De fato, parte relativa da grande quantidade de ingestão energética das mães durante os dias 30-55 de gestação podem ser armazenados como gordura para ser usada durante as duas últimas semanas de gestação. Tal estratégia pode ser vantajosa porque evita que a mãe tenha de gastar um longo tempo em forrageio justamente na época em que sua mobilidade fica reduzida (Künkele, 2000b).

Albers et al. (1999a) pesquisaram estilos maternos em cobaias (ocorrência de diferenças individuais consistentes ao longo do tempo em relação a parâmetros de comportamento materno) ao longo de quatro ninhadas consecutivas, e observaram que mães cobaias consistentemente diferiram uma da outra em relação ao comportamento materno (comportamento afiliativo - grooming, contato ventral; agressão - por diminuir a qualidade da relação social; e locomoção - por afetar fortemente o tempo que a mãe fica em contato com o filhote). Albers et al. (1999b) observaram que mães multíparas se comportaram de forma diferente das primíparas; as mães multíparas eram mais ativas em allogrooming, farejar o pêlo e contato focinho-focinho.

\section{Objetivos da presente pesquisa}

A presente pesquisa atende à necessidade de se saber mais a respeito da aloamamentação em cobaias. São poucas as descrições existentes a respeito do fenômeno e, na sua maioria, não sistemáticas. O delineamento experimental consistiu de fêmeas mantidas sozinhas com suas ninhadas e fêmeas pareadas que tiveram partos simultâneos ou quase (no máximo com 3 dias de diferença entre os partos), durante um período de 4 semanas, que é o período normal de lactação das cobaias. O problema que se colocou desde o início da pesquisa - além da necessidade descritiva - foi o de entender, de um ponto de vista funcional, o desenvolvimento da aloamamentação. Sendo o leite um recurso tão escasso para as cobaias, como entender que ocorra partilha do recurso entre filhotes próprios e filhotes alheios em condição de pareamento? 
Uma explicação de que a aloamamentação em cobaias ocorria devido a uma organização social muito permissiva - análoga à amamentação comunal em camundongos - aventada no começo da pesquisa, precisou ser reformulada à medida que analisávamos os resultados. A imagem que parece impor-se é de um fenômeno complexo em que predomina o interesse das mães pela própria ninhada e em que a busca do recurso em mães alheias é uma iniciativa dos filhotes. 


\section{ETAPA 1: COBAIAS COMUNS}

Sujeitos

Foram usadas 28 fêmeas coloridas com suas ninhadas (total de 72 filhotes) provenientes do Biotério da Fundação Parque Zoológico de São Paulo. Destas 28 fêmeas, 10 foram observadas na condição Fêmeas Sozinhas (FS - uma fêmea sozinha com sua ninhada em cada caixa experimental) e 18 fêmeas na condição Fêmeas Pareadas (FP - condição em que as fêmeas são pareadas logo após o parto, uma condição que propicia a ocorrência de aloamamentação).

Os animais eram normalmente mantidos em cercados do Biotério da Fundação Parque Zoológico de São Paulo, ao ar livre, em grupos compostos por um macho dominante, dez fêmeas e várias ninhadas. A alimentação era dada duas vezes ao dia (ração, folhas verdes), a água era disponível ad lib. Os cercados eram construídos com telas de arame com trama pequena para impedirem a entrada de outros animais, e cobertos por telhas. A temperatura e o ciclo claro-escuro eram os do ambiente (Figuras 1 e 2). Os animais estavam adaptados a estas condições, e se reproduziam freqüentemente. Mostravam-se familiarizados ao tratador e demais funcionários não interrompendo seus habituais comportamentos (comer, dormir, cortejar, amamentar) na presença deles. 


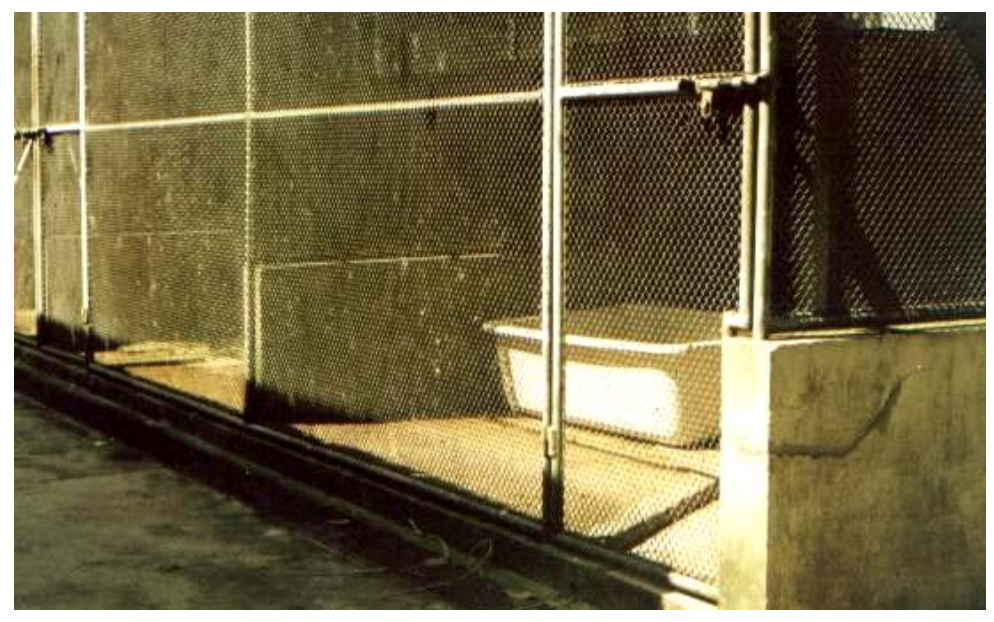

Figura 1: Caixa experimental dentro de um dos cercados do Zoológico de São Paulo.

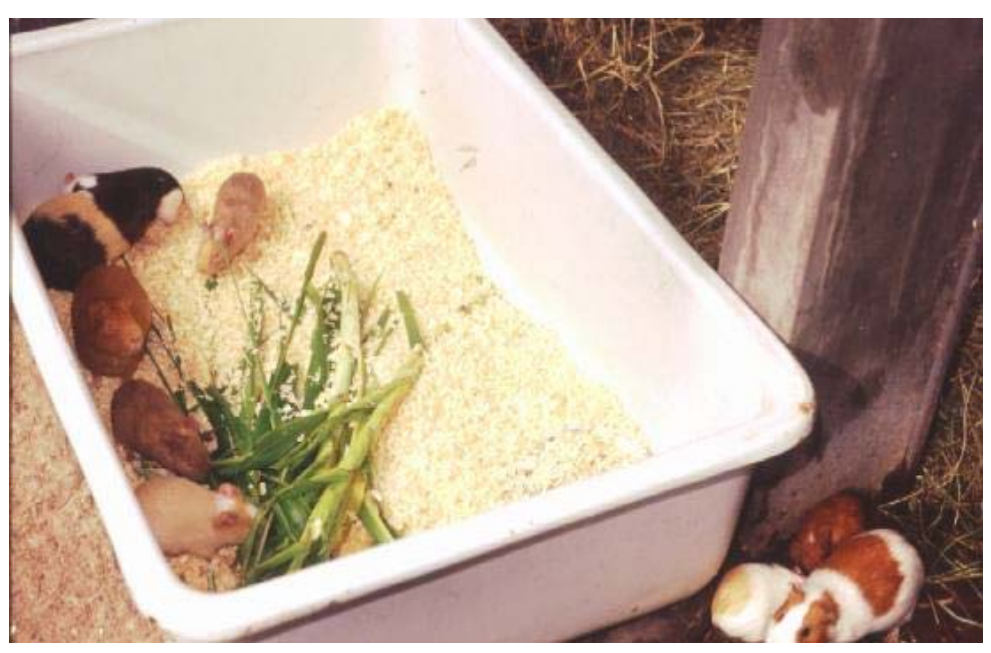

Figura 2: Fêmeas com seus filhotes, numa caixa experimental, no Zoológico de São Paulo. 


\section{ETAPA 2: COBAIAS ALBINAS}

A coleta de dados desta etapa foi realizada no Biotério Itupeva, localizada na Fazenda Bem Te Vi (em Itupeva, 80 km da cidade de São Paulo), de 10 de Janeiro a 28 de Abril de 2006. O Biotério mantém uma criação, com fins comerciais, de cobaias albinas Cavia porcellus, e outros animais de laboratório, para uso em pesquisa. Neste biotério, as cobaias eram mantidas em caixas brancas de polipropileno $(90 \times 60 \times 30 \mathrm{~cm}$ ). Em cada uma delas havia um macho, quatro fêmeas e filhotes. Os filhotes eram desmamados quando atingiam $180 \mathrm{~g}$. A temperatura e 0 ciclo claro-escuro eram naturais (Figura 3).

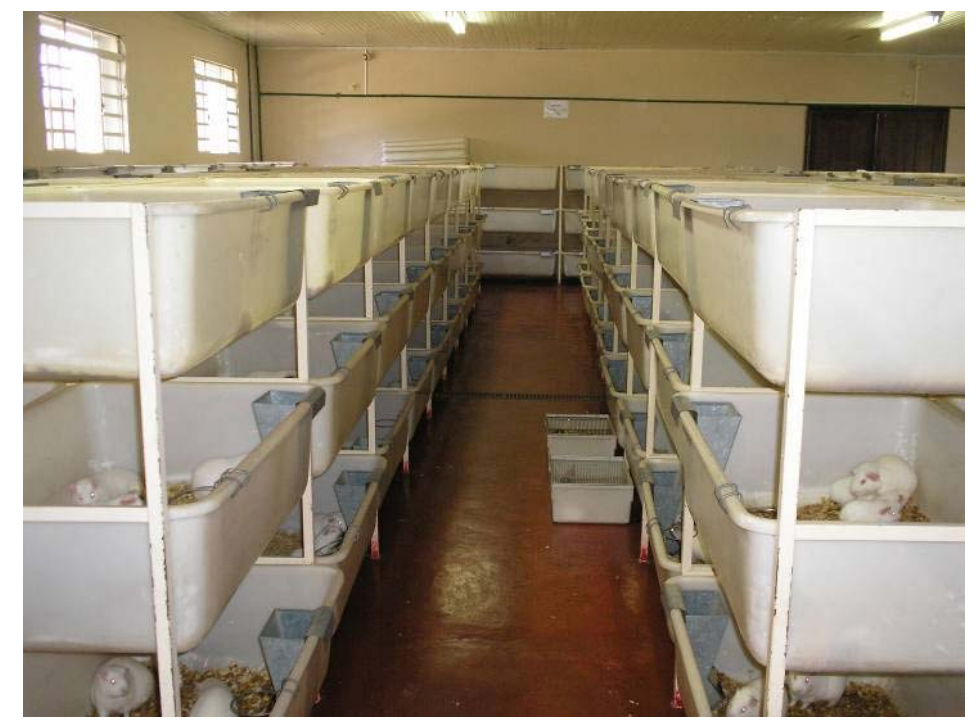

Figura 3: Sala das cobaias, no Biotério da Fazenda Bem-Te-Vi, Itupeva.

Sujeitos.

Foram usadas 30 fêmeas de cobaias albinas Cavia porcellus e suas ninhadas (total de 93 filhotes) escolhidas quando tinham acabado de dar à luz, ou quando os filhotes tinham no máximo três dias de vida. Os animais usados faziam parte do plantel do Biotério Itupeva. Das 30 fêmeas e suas ninhadas, 10 foram observadas na condição FS, e 20 fêmeas e suas ninhadas foram observadas na condição FP, formando 10 pares. 
Com o auxílio da funcionária responsável pelas cobaias checava-se diariamente as fêmeas que tinham dado à luz. Elas eram retiradas de sua caixamoradia, juntamente com os filhotes e transportadas para a sala experimental (Figura 4) onde eram mantidas em caixas de mesmas proporções $(90 \times 60 \times 30 \mathrm{~cm})$. A temperatura e o ciclo claro-escuro eram naturais.

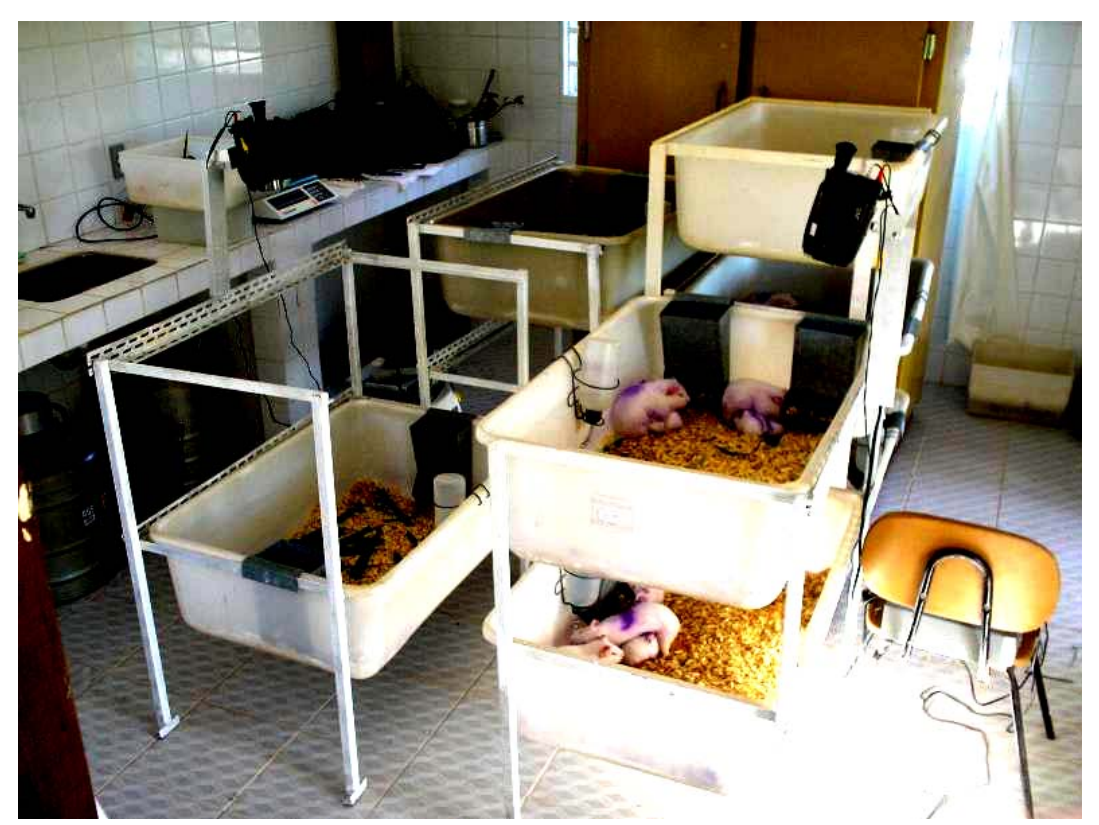

Figura 4: Ambiente experimental, na Fazenda Bem-Te-Vi, Itupeva.

Os animais recebiam água e ração ad. lib., e capim uma vez ao dia. A limpeza das caixas era feita duas vezes por semana.

\section{Procedimento}

\section{Etapa 1}

Fase de isolamento pré-parto. Fêmeas em período final de gravidez foram retiradas dos cercados e isoladas em caixas experimentais até o nascimento dos filhotes. (a) Fêmeas com partos simultâneos ou com até três dias de diferença foram colocadas na condição FP; (b) fêmeas com partos isolados foram mantidas e observadas na condição FS. 
Registro e identificação do comportamento. A duração e freqüência dos episódios de amamentação e aloamamentação foram registrados através de observação direta, durante quatro semanas pelo método de todas as ocorrências, pelo período de uma hora, duas ou três vezes por semana.

Definiu-se um episódio de amamentação, tanto na mãe própria quanto na mãe alheia, quando o filhote efetivamente pegava a mama. Este comportamento foi descrito como um comportamento de fácil identificação (Künkele e Hoeck, 1995; Künkele e Trillmich, 1997). No entanto, se a identificação for feita somente pela postura do filhote ou identificado como o filhote estando com o focinho apontado para a teta, poderá levar a um registro equivocado. Por isso consideramos a amamentação um fenômeno cuja identificação exige atenção do observador. Cabe levar em conta o momento exato em que o filhote se aproxima da fêmea, pois nesse momento é possível observar claramente se o filhote é bem sucedido em pegar a mama ou não. Se este momento passar, pode-se supor que o filhote esteja mamando quando na verdade está apenas em contato com a fêmea.

Para fins deste estudo considerou-se um episódio de amamentação e início do episódio quando se observava que o filhote pegava a mama com a boca. Durante um episódio o filhote podia eventualmente largar a mama rapidamente e depois voltar a pegá-la. Se o filhote voltasse a pegar a mama dentro de dez segundos considerava-se que se tratava ainda do mesmo episódio, se demorasse mais de dez segundos, contava-se novo episódio.

Registro da distância. A distância dos filhotes com relação à mãe e à mãe alheia, na condição FP era avaliada a partir de varreduras (scans) de distância entre mães e filhotes, a cada quinze minutos da sessão de uma hora, havendo, assim, quatro varreduras por sessão de observação. A unidade de distância considerada foi a de "um corpo de cobaia", aproximadamente $30 \mathrm{~cm}$.

Peso. Os filhotes eram pesados após o nascimento (na primeira semana de vida $=$ peso inicial) e no último dia de observação (quarta semana de vida = peso final), para se avaliar o ganho relativo de peso (peso final - o peso inicial/peso inicial). 


\section{Etapa 2}

O procedimento usado na Etapa 2 replicou, em todos os detalhes, o procedimento da Etapa 1 com diferenças no registro (os animais eram filmados) e de peso (eram pesados ao longo das 4 semanas experimentais)

Registro dos Dados. Os animais eram filmados em sessões de uma hora e dez minutos (Figura 5) com câmeras VHC Sony e JVC.

Peso. Os filhotes foram pesados antes de cada filmagem de duas a três vezes por semana durante o período de observação para obter uma estimativa do desenvolvimento ponderal (na primeira etapa, dispúnhamos dos pesos inicial e final de cada filhote).

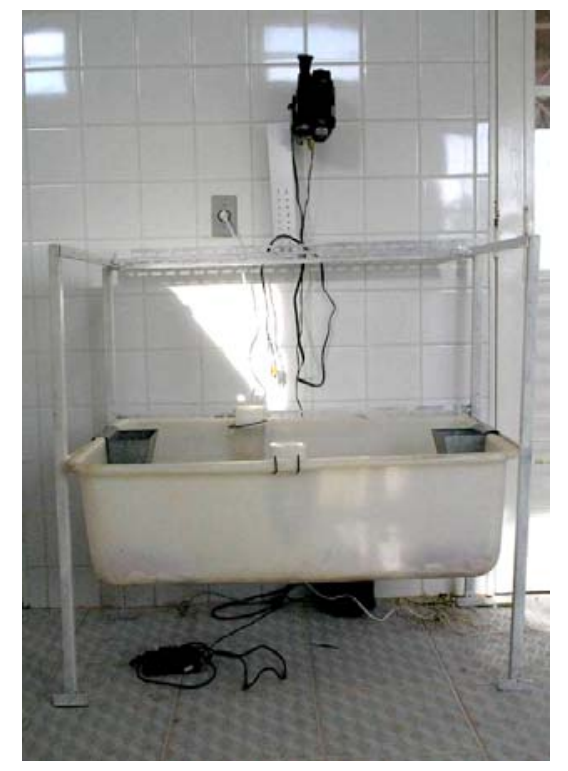

Figura 5: Dispositivo de filmagem, na Etapa 2: disposição da câmera VHS e da caixa de cobaias. 


\section{Análise estatística}

Foram 5 as variáveis dependentes analisadas: distância fêmea-filhote, freqüência média de amamentação; duração média total de amamentação, duração média por episódio de amamentação e ganho relativo de peso dos filhotes. (1) A distância média fêmea-filhote foi calculada dividindo-se o total das distâncias registradas pelo número de episódios; (2) as freqüências médias de amamentação foram computadas dividindo-se o número total de episódios de amamentação durante a semana pelo número de sessões de observação desta semana. (3) A duração total de amamentação em cada semana, dividida pelo número de sessões, fornecia a duração média de amamentação; (4) a duração por episódio foi obtida dividindo-se a duração média de amamentação pelo número de episódios observados; (5) o peso dos filhotes era tomado na primeira semana de observação e na quarta semana, na Etapa 1; e semanalmente, na Etapa 2.

Para comparar os grupos de interesse ao longo do tempo, quanto às variáveis de freqüência, duração total, duração por episódio, distância e peso utilizou-se uma Análise de Variância para Medidas Repetidas (Winer, 1971; Diggle et al., 1994). Essa metodologia permite avaliar se o comportamento médio das variáveis ao longo das condições de avaliação é semelhante nos quatro grupos [FS, FPp, FPa(p+a) e FPp $(p+a)$, para cada etapa, ver legenda nos resultados], ou seja, se as curvas médias dos grupos são paralelas, que corresponde à hipótese de ausência de interação entre condição de avaliação e grupo. Caso essa hipótese não seja rejeitada, prossegue-se a análise testando efeito de grupo e efeito de condição de avaliação, sendo que o interesse foi comparar os momentos consecutivos. Caso contrário, prossegue-se a análise através da comparação das médias dos grupos dentro de cada momento e dos momentos dentro de cada grupo. Para modelar a dependência entre observações dos filhotes da mesma mãe ou de filhotes de mães pareadas incluiu-se no modelo estatístico os efeitos aleatórios. Esse método garante que as comparações entre as médias sejam feitas ponderando-se pela dependência das observações relacionadas. O nível de significância estabelecido para análise foi de $5 \%$. 
Comparou-se o número de filhotes que mamaram e alomamaram nas condições FS, FPp, $F P a(p+a)$ e $F P p(p+a)$ através do teste de $\chi^{2}$. 
$\mathrm{Na}$ apresentação dos resultados serão usadas siglas para indicar os grupos de indivíduos observados:

FPp. Dados referentes ao comportamento dos filhotes que mamaram exclusivamente de suas mães, na condição FP.

$F P(p+a)$. Dados referentes ao comportamento dos filhotes que mamaram da mãe própria e da mãe alheia, na condição FP. Distinguiu-se, neste conjunto de dados:

$\mathrm{FPp}(\mathrm{p}+\mathrm{a})=$ comportamento dos filhotes em relação à mãe,

$\mathrm{FPa}(\mathrm{p}+\mathrm{a})=$ comportamento dos mesmos filhotes em relação à outra fêmea (mãe alheia).

Também foram usadas siglas para nomear indivíduos. As fêmeas eram designadas por letras maiúsculas (FP1, por exemplo): FP significa "fêmeas pareadas", o número (1, no caso) a família. Os filhotes foram identificados com letras minúsculas (fp1a e fp1b, por exemplo). As primeiras letras (fp) indicam a condição; o número seguido por uma letra indica, no caso, que os dois filhotes pertencem à família 1, filhos de FP1. 


\section{OBSERVAÇÃO QUALITATIVA DO COMPORTAMENTO NO CONTEXTO DE PAREAMENTO}

Descrevemos aqui, usando como base os registros de videotape obtidos na Etapa 2, aspectos gerais do comportamento dos filhotes e das mães cobaias no contexto de fêmeas pareadas (FP). Esta descrição visa um conhecimento maior das interações no contexto FP (não existem, na literatura, relatos qualitativos extensos a respeito de como se comportam fêmeas e filhotes numa situação de ninhadas simultâneas) e fornece uma base descritiva relevante para a interpretação das análises quantitativas que fornecemos em seguida. Algumas das perguntas que nos colocamos, ao observarmos as duas famílias, no contexto FP eram: Há segregação espacial e comportamental das famílias? Há comportamentos agonísticos entre as fêmeas? Há agressão seletiva das fêmeas em relação a filhotes alheios ou, pelo menos, comportamentos que limitem o seu acesso às mamas? Há competição entre os filhotes em relação ao acesso às mamas? Como se dá a iniciação de um episódio de amamentação? A fêmea lactante tem sempre contato com o filhote antes do episódio de amamentação? Há reconhecimento? Ela pode decidir se oferece seu leite a um filhote próprio ou a um filhote alheio?

\section{PROXIMIDADE E AGRESSÃO}

Agrupamentos de descanso: Os animais em descanso ou parados formam muitas vezes um aglomerado em que os animais mantêm contato corporal estreito, cada animal assumindo uma postura individual. Destes agrupamentos fazem parte filhotes de mães diferentes, não havendo indício de segregação por família (Figura 7, página 40). Para Rood (1972), há descanso quando o animal se deita com o ventre e queixo em contato com o chão, patas traseiras para o lado ou esticadas para trás. King (1956) atribui ao descanso o contato que ocorre nos agrupamentos sendo a sua função a de preservar o calor corporal.

Contato entre filhotes: Os filhotes das duas ninhadas ficam uns perto dos outros, alimentam-se ao comedouro juntos, misturam-se sem padronização espacial clara, embora exista a tendência de seguirem a mãe e permanecerem perto dela 
(Figuras 10 e 15). Não há agressão marcada, fora pequenos movimentos de afastamento (por exemplo, a movimentação rápida da cabeça ou do corpo que um filhote executa quando outro se aproxima e quase estabelece contato com o focinho) e uma competição possível perto da mama disputada.

Filhotes seguem a fêmea: O comportamento de seguir a fêmea é um dos mais constantes nos filhotes e é o que constitui a base para uma certa separação espacial entre as famílias, na medida em que os filhotes tendem a seguir mais a sua própria mãe do que a outra. Ocorre, contudo seguimento de filhotes em relação à fêmea que não é sua mãe. Ao seguir, os filhotes ficam (individualmente ou em grupo) atrás da mãe, ou paralelos a ela, parando eventualmente quando ela pára (Figura 10a) às vezes tentam mamar depois de ela parar (Figura 10b). Não observamos diferença entre filhotes próprios e alheios no jeito de seguir a fêmea. Fullerton et al. (1974) observaram o mesmo padrão em seu estudo com cobaias. Os autores verificaram que os filhotes ficavam mais freqüentemente em contato e próximos de suas próprias mães, mas estas atividades ocorreram em menor grau em relação à outra fêmea.

Contato e agressão entre fêmeas: As fêmeas ficam geralmente próximas umas das outras, em descanso (Figura 7) e passam freqüentemente uma perto da outra durante sua locomoção pela caixa (Figura 9). Mas pode ocorrer de uma fêmea agredir outra quando uma se aproxima ou passa perto. Nos quadros da Figura 8, vemos uma fêmea agredir e perseguir outra. Os atos agonísticos incluem bater com o focinho e dar patadas. Rood (1972) relata serem raras as interações agressivas entre fêmeas: ocasionalmente, uma fêmea mais velha, com um empurrão de cabeça, afastava outra mais nova do comedouro ou do lugar de descanso. Segundo ele, estes episódios não eram suficientemente freqüentes para caracterizar o estabelecimento de relações de dominância. Segundo ele, as cobaias fêmeas são passivas e de natureza amigável. Nossa observação confirma o caráter benevolente das fêmeas, mas mostra que ele coexiste com atos agressivos e o possível estabelecimento de dominância.

Agressão das fêmeas aos filhotes: As fêmeas são geralmente benevolentes para com os filhotes, sejam próprios ou alheios. Contudo, episódios de agressão leve foram observados e têm possível relevância para a compreensão do processo de amamentação e aloamamentação. Fêmeas (ver mais adiante) podem interromper 
agressivamente um episódio de amamentação. Mas elas também podem agredir filhotes que estejam passando perto com movimentos bruscos da cabeça ou do corpo. A observação indica serem estas agressões mais freqüentes no caso de filhotes alheios do que dos próprios: se verificada esta observação, teríamos um indício do porquê os filhotes preferem mamar de sua mãe e do porquê, como será vista mais adiante, a freqüência de filhotes que alomamam cai desproporcionalmente depois da primeira semana de vida.

\section{INÍCIAÇÃO DO EPISÓDIO DE AMAMENTAÇÃO}

Abordagem individual à fêmea: Não observamos diferença na maneira de a fêmea ser abordada por seu filhote ou por um filhote alheio para a iniciação da amamentação. A abordagem para amamentação nem sempre inclui um exame ou contato sensorial do filhote pela fêmea que o amamentará, o que favorece a hipótese de que não há controle sistemático do acesso à mama nem seletividade a favor dos filhotes próprios. Em muitos episódios, a fêmea simplesmente é procurada por um filhote que vem por trás e não há indicação de que ela possa efetuar o reconhecimento ou impedir a sua aproximação.

O filhote, em muitos dos episódios, se aproxima diretamente da fêmea, colocando o focinho sob o ventre dela para alcançar a mama, mantendo um ângulo variável ao corpo dela, mas visando a região das mamas. Não há, neste caso, contato prévio do filhote com a fêmea para que ela pudesse reconhecê-lo (se próprio, se alheio) e não parece haver qualquer possibilidade de ela interromper seletivamente a aproximação do filhote. O filhote entra lateralmente, por debaixo da fêmea, sem que haja contato focinho-focinho ou outra forma de aproximação sensorial da fêmea em relação ao filhote (Figuras 12a, 13a e 14a).

Em outros casos, o contato sensorial próximo ocorre. A fêmea encosta o focinho no filhote que está se aproximando para mamar, conseguindo farejá-lo (Figuras 11c e 12d). Estes casos indicam que a iniciação da amamentação não é sempre "cega", do ponto de vista da fêmea e que há eventualmente conhecimento, de sua parte, a respeito da identidade (próprio/alheio) do filhote. Não sabemos se o contato sensorial propicia respostas de rejeição seletiva que favoreçam o filhote próprio. 
Abordagem conjunta à fêmea: Os filhotes às vezes se dirigem juntos para a fêmea, iniciando um episódio de amamentação (Figura 14a). Os filhotes que mamam (ou procuram mamar) simultaneamente podem ser irmãos (Figura 16), ou não (um filhote próprio + um filhote alheio) ou podem ser ambos alheios. A chegada à fêmea, por parte do filhote alheio, não parece obedecer a uma regra do tipo: "aproximar-se da fêmea se ela já estiver amamentando um filhote próprio", ou "aproximar-se junto com um filhote próprio", como ocorre em búfalos (Murphey et al., 1995) e cervos (Birgersson et al., 1991 e Ekvall, 1998).

Os filhotes ajeitam-se espacial e posturalmente quando chegam ao mesmo tempo à fêmea: cada um acaba situando-se na região de uma das mamas. Quando um filhote encontra outro mamando, dirige-se diretamente para a outra mama, um comportamento que pode significar uma redução da competição direta. A competição, no sentido de um filhote tentar desalojar outro que já esteja mamando, ocorre quando ambas as mamas estão ocupadas na chegada de um terceiro filhote e se caracteriza por movimentos de aproximação à região da mama associados com empurrões laterais dirigidos ao outro filhote. Às vezes, quando um filhote pára de mamar, um filhote que está próximo logo começa a mamar em seu lugar.

\section{POSTURAS E COMPORTAMENTOS DE AMAMENTAÇÃO}

Fêmea sentada : A fêmea está na posição sentada, região traseira do corpo encostada ao chão, torso erguido, e com as quatro patas apoiadas. O ventre não está, neste caso, apoiado por inteiro sobre o chão. (1) Um ou dois filhotes mamam frontalmente: o filhote (ou os filhotes) se arrastam por entre as patas dianteiras da fêmea para alcançar a mama, havendo um contato de suas costas do filhote com o ventre da fêmea (figura 11c e 11d). (2) Um ou dois filhotes mamam lateralmente: o filhote (ou os filhotes) está com apenas a cabeça sob o ventre da fêmea e com o corpo exposto (Figura 13c).

Fêmea deitada com um filhote mamando lateralmente: A fêmea tem o ventre todo apoiado ao chão e nesta posição é possível que somente um filhote mame; este filhote só pode mamar na posição lateral, pois não é possível que ele passe pelas patas dianteiras da fêmea (Figura 14c). 
Estimulação do filhote pela fêmea durante a amamentação. Enquanto amamenta, a fêmea pode, simultaneamente, realizar estimulação ano-genital no filhote que mama (Figura 12b e 12e). Não temos uma contagem do quanto este comportamento ocorre dirigido para um filhote próprio ou para um filhote alheio, mas sabemos que ele ocorre nos dois casos. Quando estimulado, o filhote se vira, fica com o ventre para cima, e levanta uma das patas traseiras. O filhote faz movimentos rápidos e repetidos com a pata levantada, para frente e para trás, e pode emitir vocalização característica de estimulação. King (1956) descreve a estimulação anogenital como sendo a única interação social associada ao comportamento eliminativo, e ocorre quando a mãe lambe a região anal, enquanto o filhote relaxa e permite ser virado de lado pela mãe e ao mesmo tempo emite uma série de grunhidos.

Assim descreve Rood (1972) a amamentação em cobaias: a fêmea se senta com as patas dianteiras estendidas, olhos parcialmente fechados, ou se põe deitada sob o ventre ou de lado. Uma amamentação casual ocorre quando a fêmea está comendo ou bebendo. Uma fêmea que amamenta pode ocasionalmente se inclinar, lamber e esfregar o focinho na região ano-genital do filhote, para estimular a eliminação. Os filhotes freqüentemente mamam com o quadril elevado o que facilita a estimulação ano-genital pela fêmea.

\section{A TERMINAÇÃO DA AMAMENTAÇÃO}

O fim da amamentação se dá sob a iniciativa do filhote que interrompe espontaneamente o episódio e se afasta ou da fêmea que força esta interrupção: (1) A fêmea se afasta, em locomoção, e assim se desliga do filhote (Figura 8). Em alguns casos, o filhote continua segurando a mama e chega a ser arrastado. (2) A fêmea agride o filhote: ela pode virar-se, lateralmente, e dar um golpe com o focinho no filhote que está mamando (Figura 16), ou ela pode efetuar um movimento brusco com a pata, que freqüentemente atinge o filhote e o afasta dela. Vimos a interrupção agonística da amamentação ser dirigida tanto para filhotes próprios como para filhotes alheios e notamos que era mais freqüente na época próxima ao desmame. 


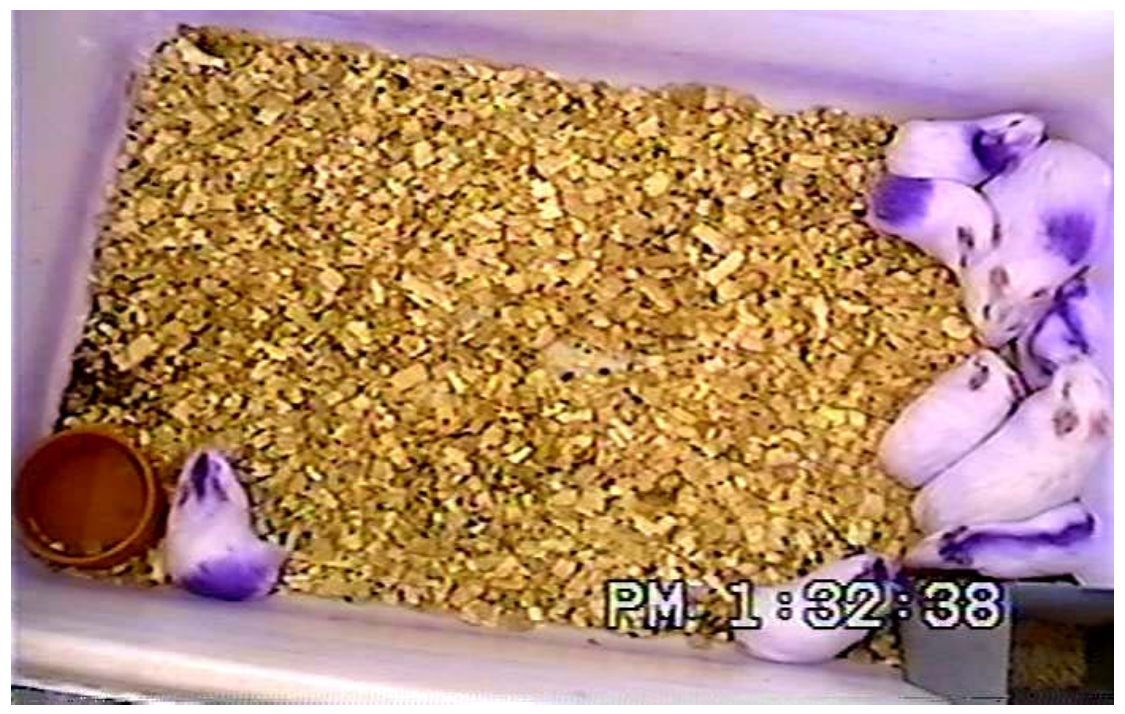

Figura 7: Exceto por um filhote próximo à tigela, todos os indivíduos das duas famílias se mantêm agrupados. 

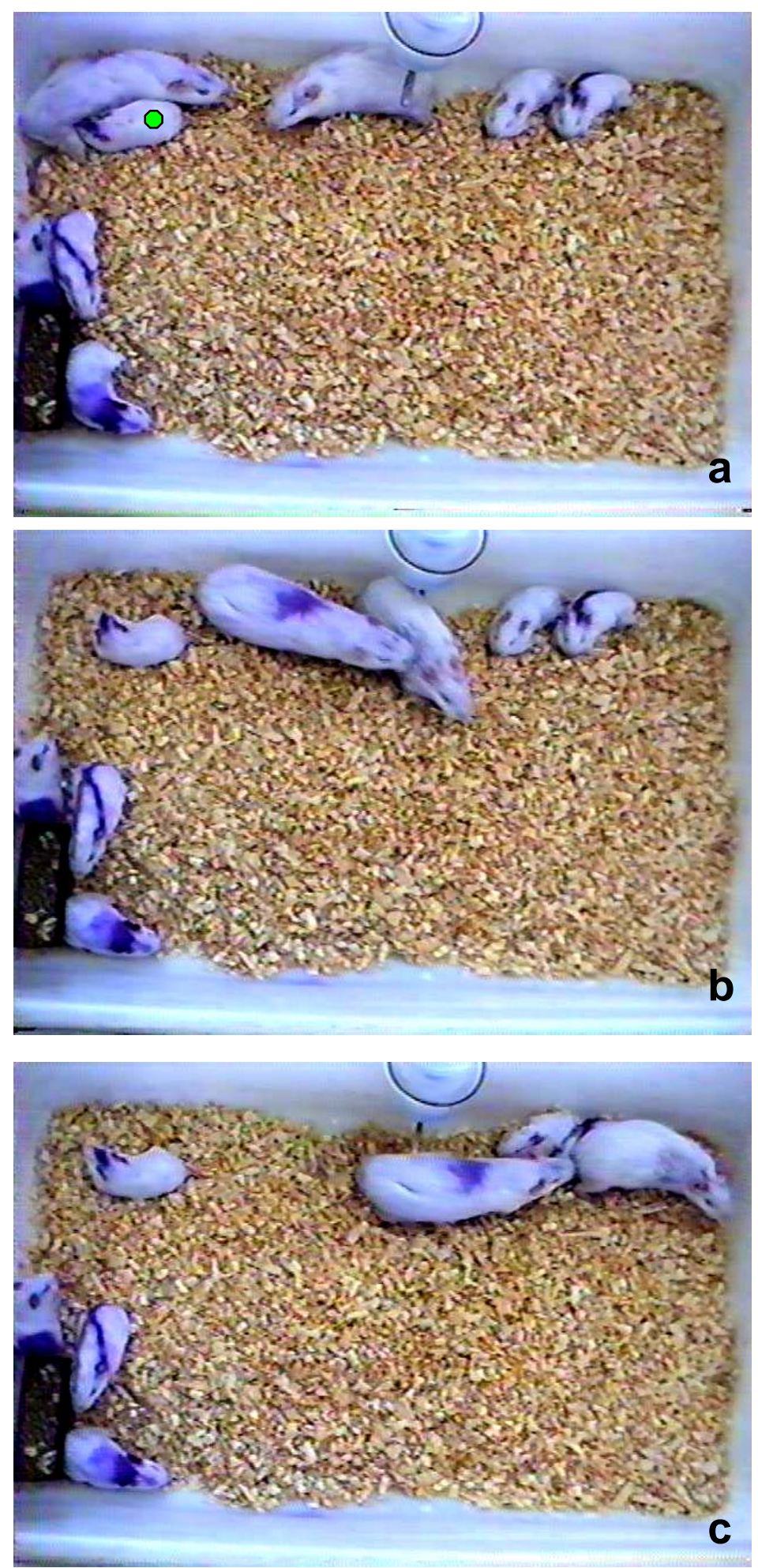

Figura 8: (a) FP7 (mancha nas costas), amamenta filhote próprio fp7a (círculo verde) quando FP8 (sem mancha), se aproxima; (b) FP7 agride FP8; a amamentação fica interrompida (c) FP8 foge e FP7 a persegue. 

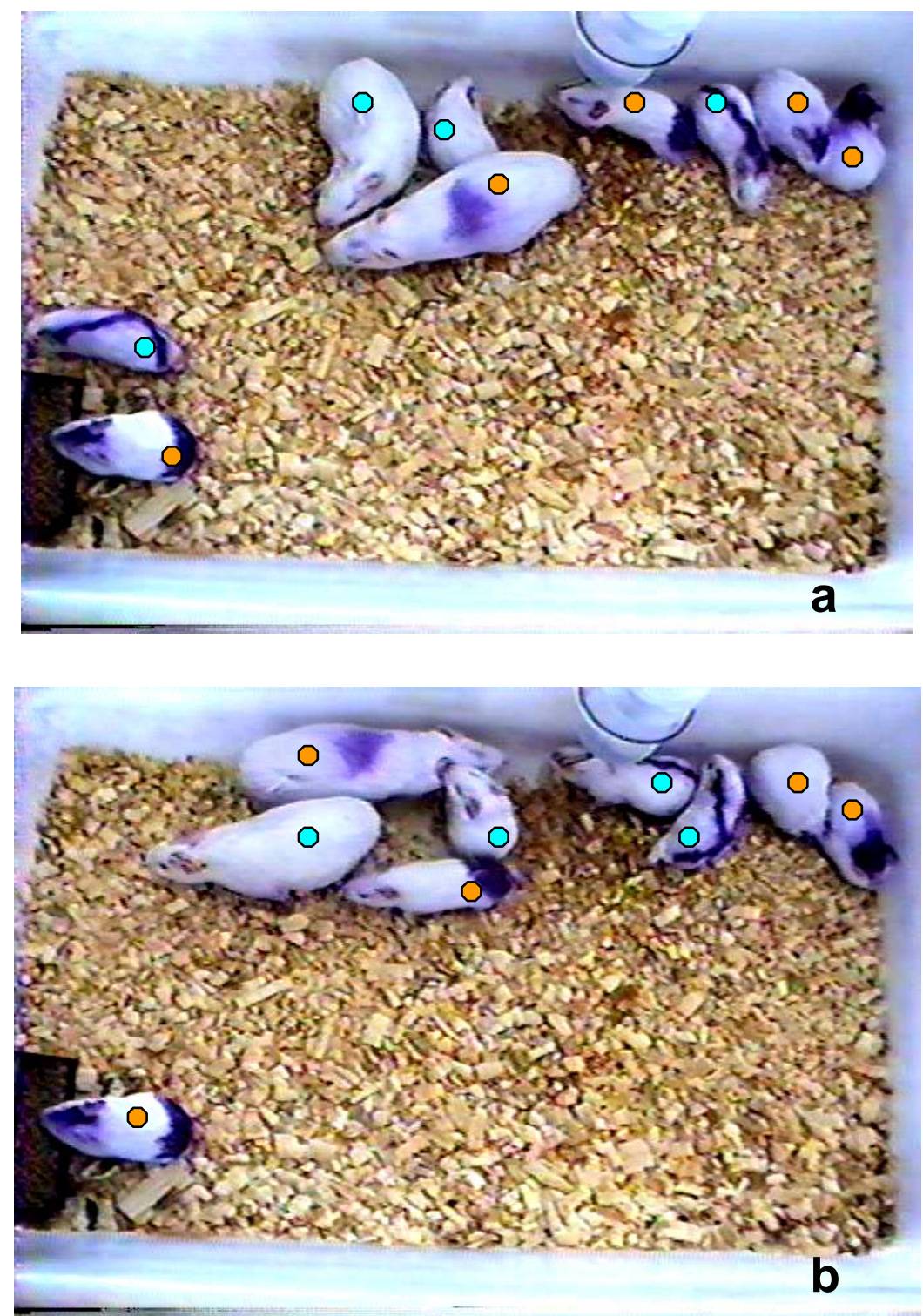

Figura 9: FP7 (mancha nas costas) e seus filhotes são indicados pela cor laranja, e FP8 (sem mancha) e seus filhotes pela cor azul. (a) as fêmeas se encontram brevemente, quando FP7 passa por FP8; (b) FP7 passa novamente por FP8. Durante a atividade ocorre uma mistura dos indivíduos. 

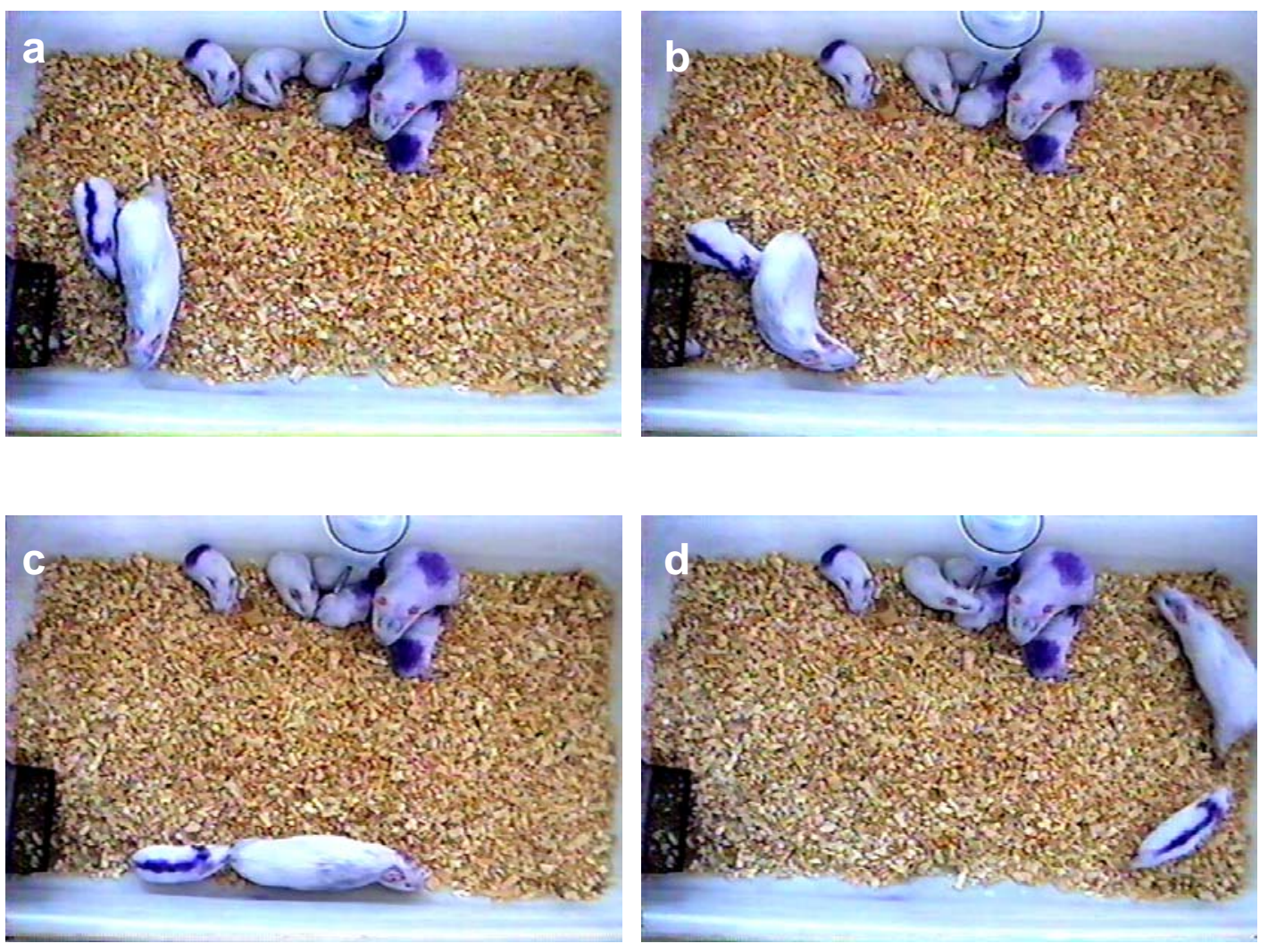

Figura 10. (a) FP8 (sem mancha) e seu filhote fp8b (listra nas costas) se locomovem em paralelo; (b) fp8b coloca o focinho no ventre de FP8, que parou um instante, e tenta mamar; (c - d) fp8b se locomove atrás de FP8, o focinho a pequena distância ou em contato com a região traseira da mãe. Enquanto isso, FP7 (mancha no dorso) amamenta dois de seus filhotes. 

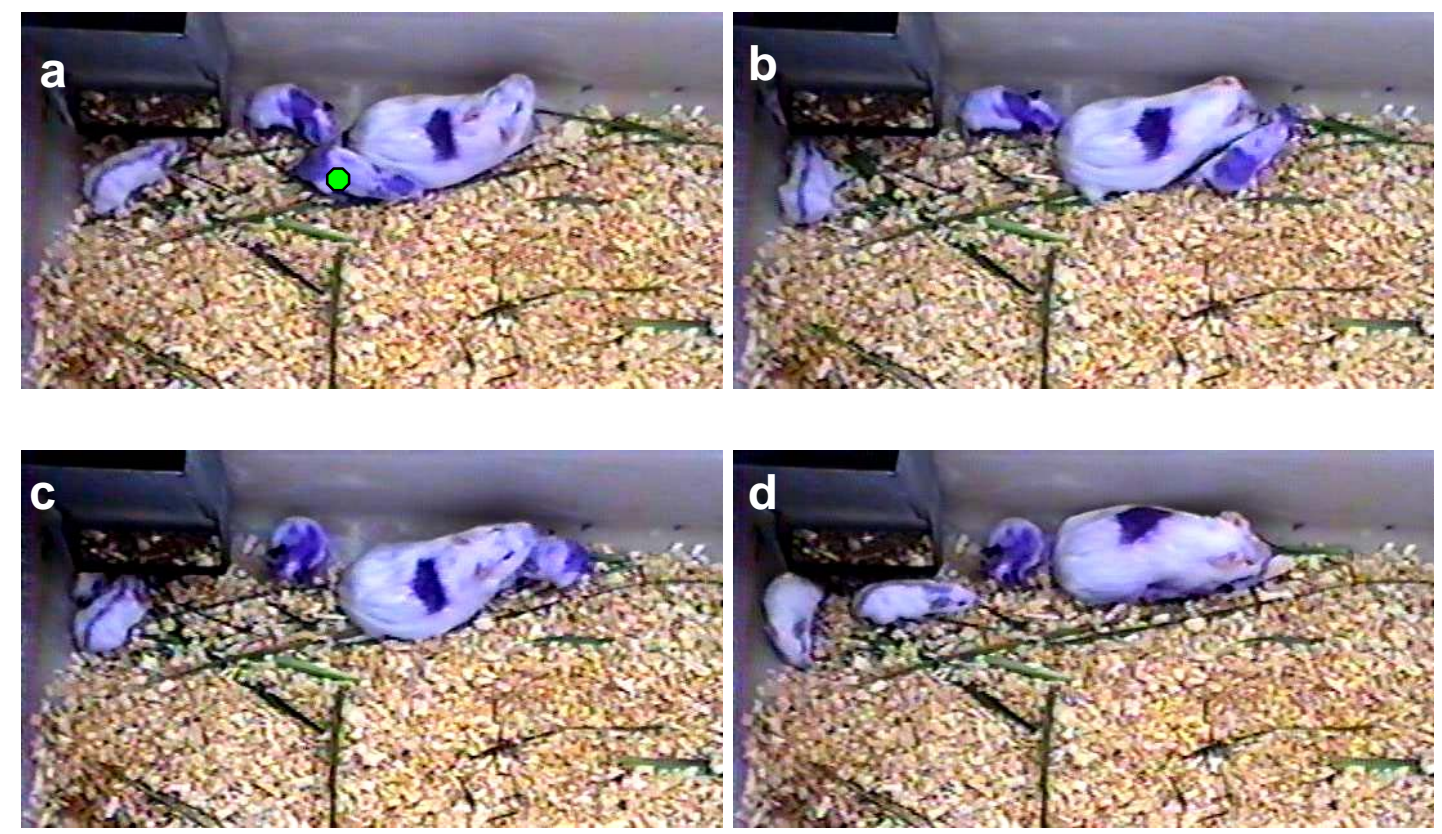

Figura 11: (a) fp7d, mancha cabeça+traseira (verde) contorna o corpo da mãe, FP7, parada; (b) fp7d se aproxima da cabeça de FP7, sendo possível o contato sensorial; (c) fp7d coloca a cabeça sob a cabeça de FP7; (d) fp7d se arrasta debaixo de FP7 e alcança a mama. 

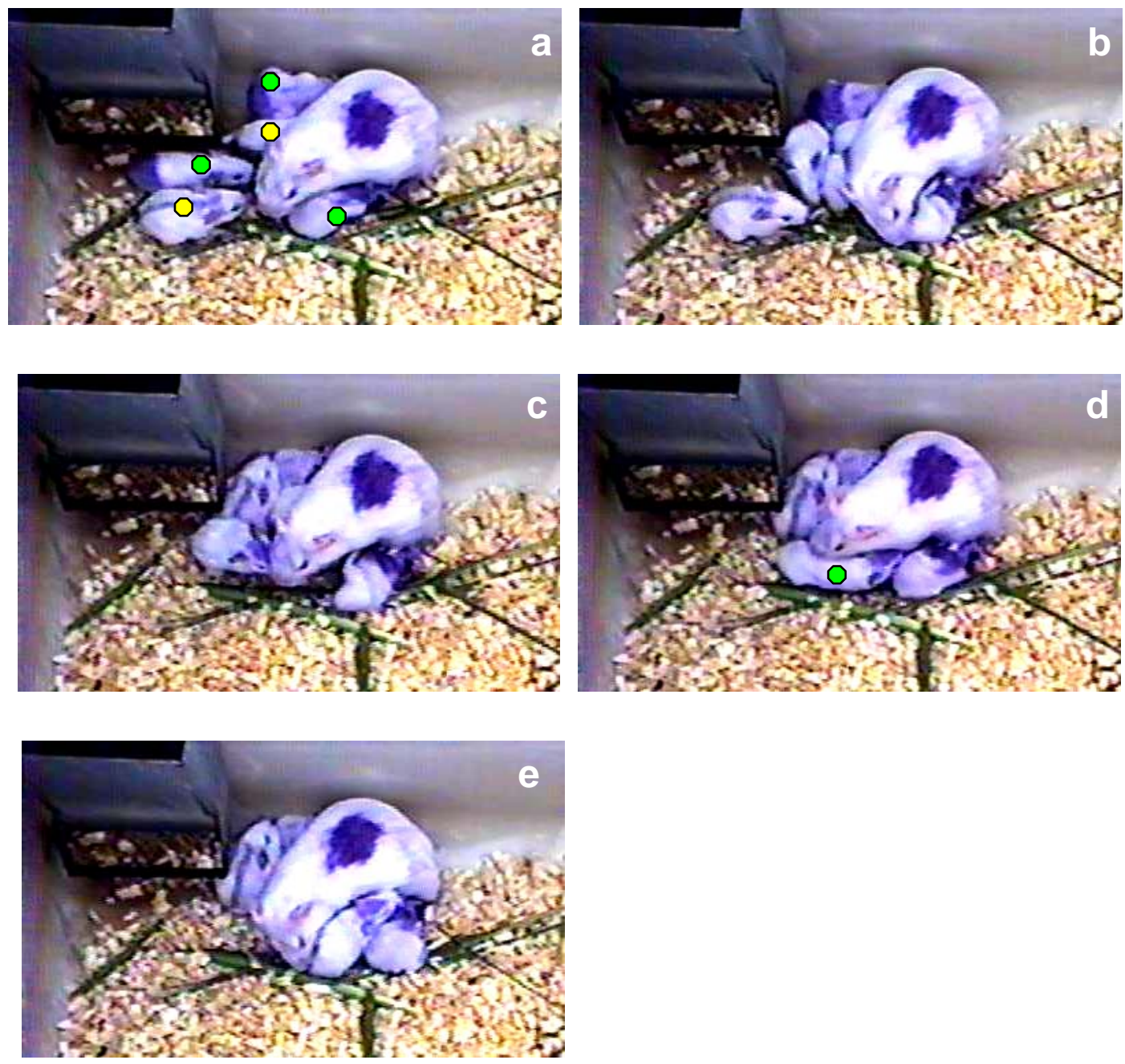

Figura 12: (a) os filhotes, próprios e alheios, vão em direção a FP7, o filhote fp7b (verde) consegue mamar; (b) FP7 abaixa a cabeça e inicia estimulação ano-genital em fp7b, que levanta a pata traseira; (c) fim da estimulação anogenital de fp7b; (d) fp7a, mancha cabeça (verde), aproxima-se de FP7 frontalmente e é farejado por FP7 (contato sensorial); (e) FP7 abaixa a cabeça em direção à região ano-genital de fp7a. 

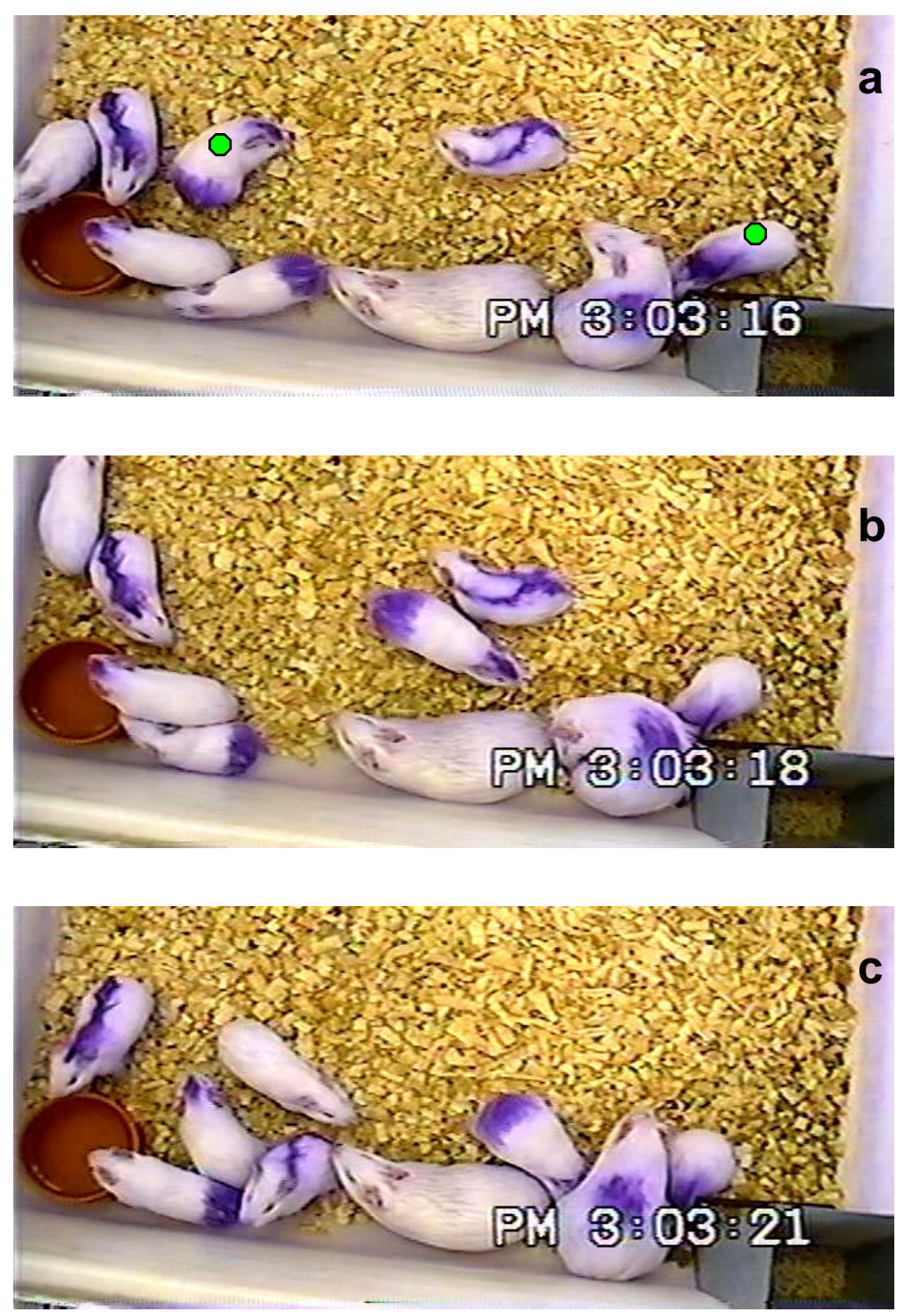

Figura 13: (a) fp7c, mancha no pescoço (verde) aborda FP7 (mancha nas costas), enquanto o irmão fp7d, mancha cabeça+traseira (verde) encontra-se a uma certa distância; (b) o filhote fp7c mama enquanto fp7d se aproxima de FP7, passando ao lado da mãe alheia FP8 (sem mancha); (c) os filhotes fp7c e fp7d mamam juntos. 

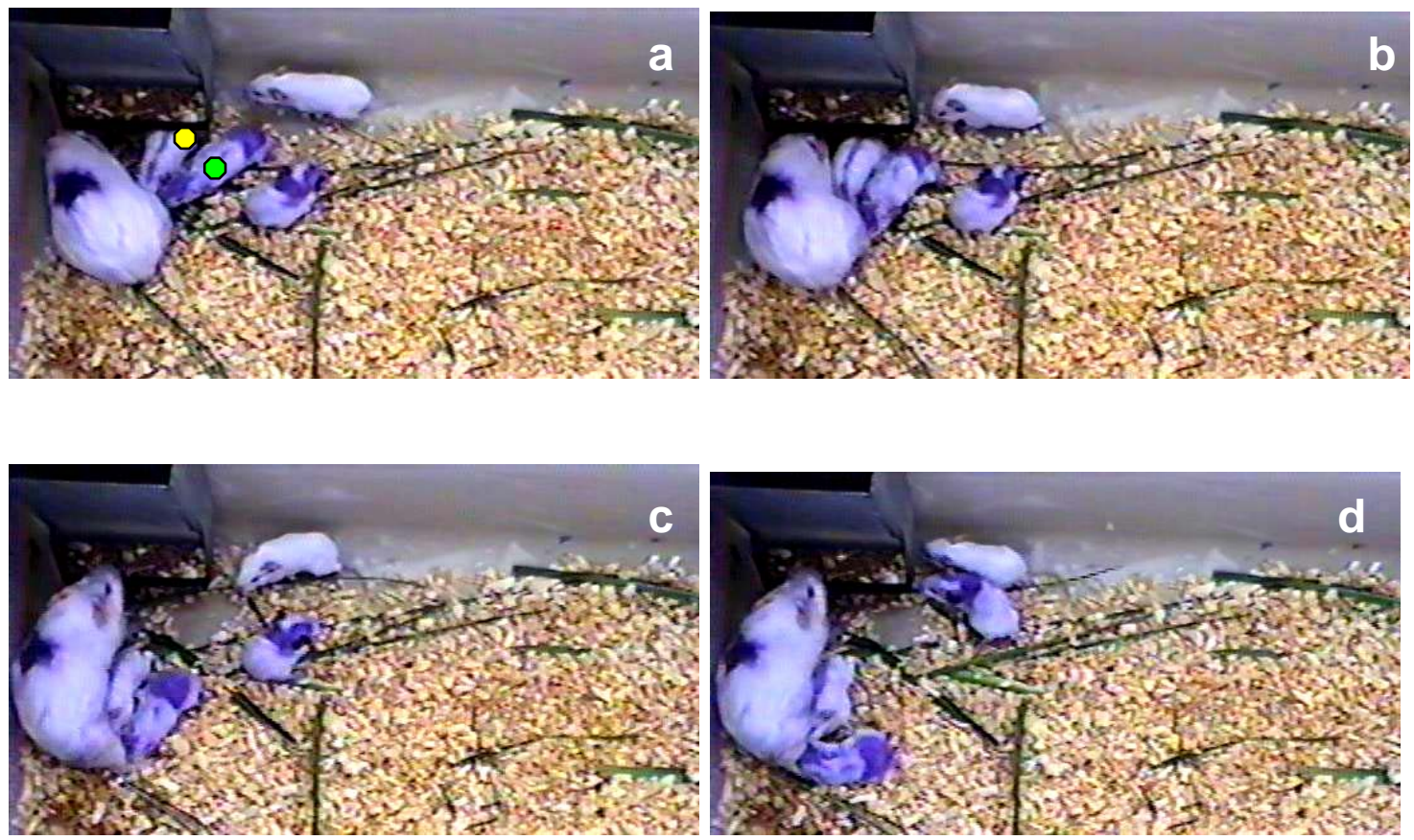

Figura 14: (a) fp8b, listra nas costas (amarelo), filhote alheio, está mamando em FP7 quando o filhote próprio fp7d, mancha cabeça+traseira (verde), se aproxima; (b) fp7d enfia o focinho para pegar a mama; (c) fp8b não larga a mama e os dois filhotes se empurram; (d) os filhotes se empurram, e empurram a pata de FP7. O filhote alheio fp8b continua mamando e fp7d fica perto sem mais competir. 

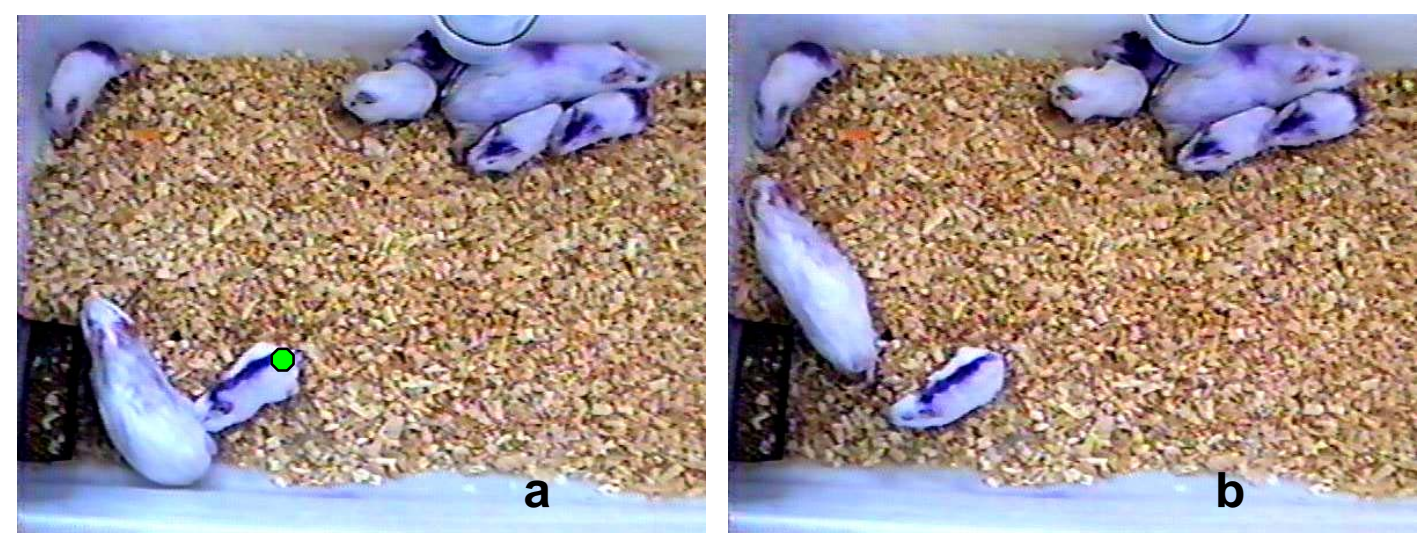

Figura 15: (a) fp8b, listra nas costas (verde), mama lateralmente em FP8; (b) FP8 interrompe amamentação afastando-se de fp8b.
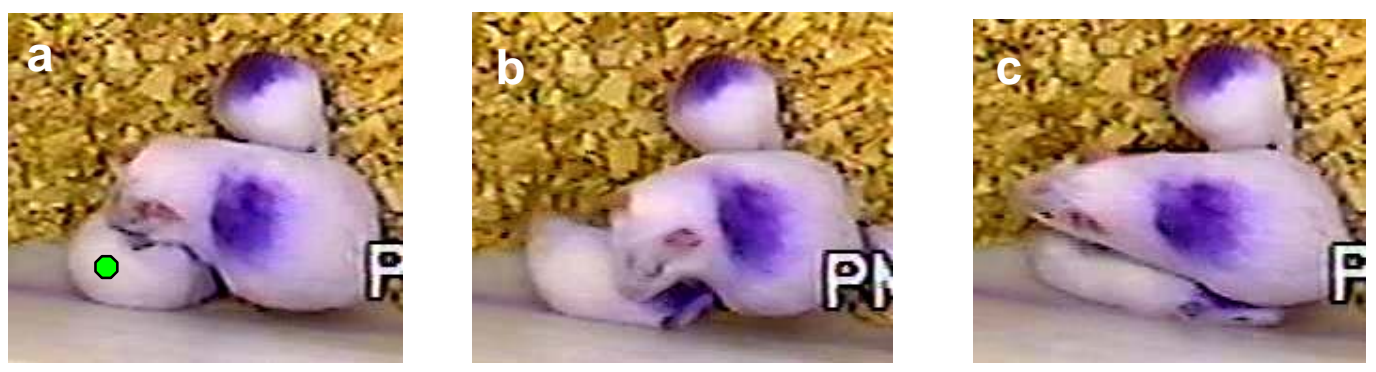

Figura 16: (a) Filhotes próprios fp7a (mancha na cabeça) e fp7c (mancha traseira), mamam em FP7; FP7 está com o focinho em contato com fp7a (verde); (b) FP7 vira a cabeça na direção da cabeça de fp7a, à sua esquerda, e bate nele com o focinho; (c) fp7a larga a mama e tenta se afastar passando pelo espaço entre FP7 e a parede da caixa. 

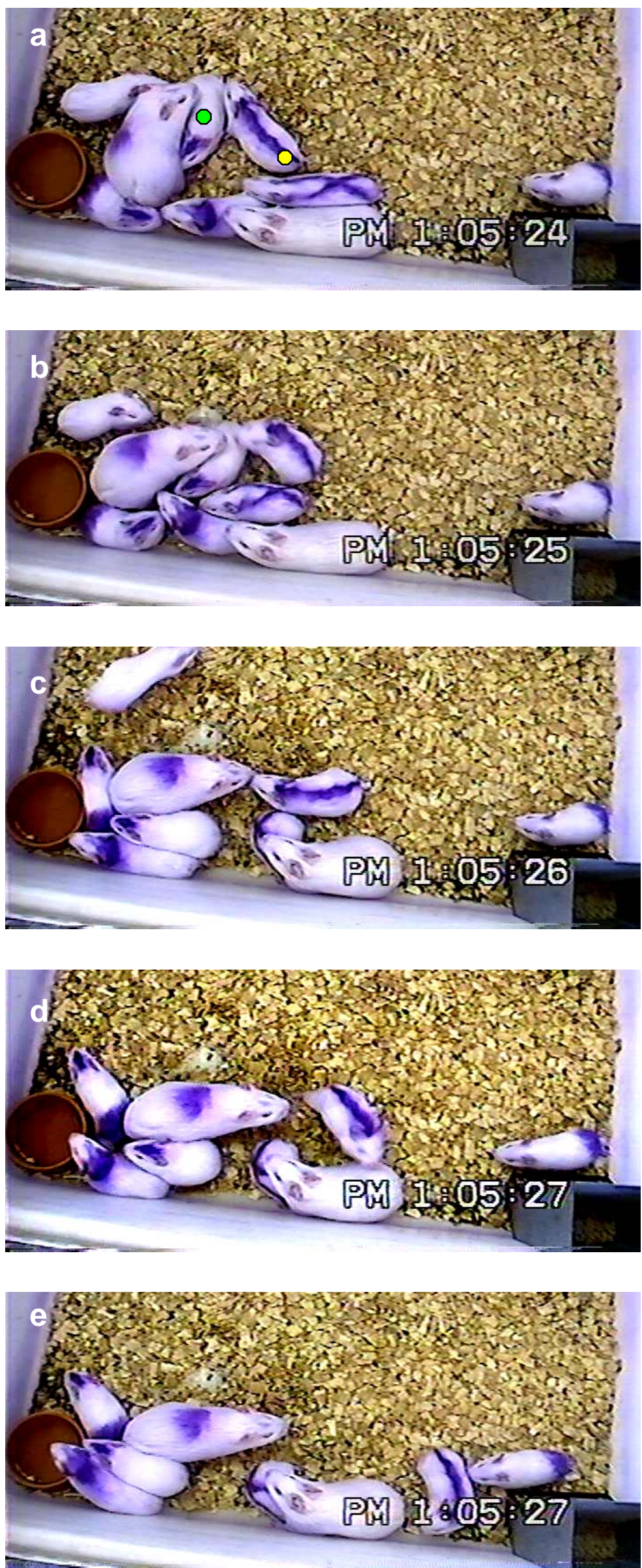
Figura 17: (a) FP7 amamenta filhote próprio fp7a, mancha na cabeça (verde); o filhote alheio fp8b, listra nas costas (amarelo) está próximo; (b) FP7 dá uma focinhada no focinho de fp8b, que imediatamente recua; o filhote próprio fp7a deixa a mama durante o ataque; (c) FP7 e fp8b entram em contato focinho/focinho; (d) FP7 dá outra focinhada em fp8b, que recua e (e) afasta-se de FP7.

As observações diretas do comportamento, na condição FP, confirmam o caráter geralmente pacífico das interações de cobaias em situação de biotério. As cobaias descansam muitas vezes em conjunto e se mesclam, ao longo do tempo, de uma forma que indica não haver discriminação marcada entre as famílias ou, pelo menos, não ser esta discriminação marcada e estabelecedora de territórios. Apesar desta coexistência social tranqüila, existem laços de proximidade mais marcados entre os filhotes e suas mães do que entre eles e a outra fêmea, e eventos agonísticos entre fêmeas e entre fêmeas-filhotes. Os ataques de fêmeas a filhotes que mamam podem ser entendidos como fazendo parte do processo de desmame, ou do equilíbrio entre a disponibilidade de a fêmea amamentar e de os filhotes procurarem as mamas. Mas os ataques espontâneos a filhotes, talvez direcionados a filhotes alheios, podem ser a maneira que as fêmeas encontraram de defender 0 leite enquanto recurso para os próprios filhotes (uma vez que não parecem aptas a discriminar os filhotes que estejam mamando, nem capazes de afastar seletivamente os filhotes alheios). 


\section{RESULTADOS QUANTITATIVOS}

A análise dos registros quantitativos foi efetuada, basicamente, a partir das três seguintes comparações:

(1) FS $x$ FPp: através desta comparação, é possível verificar o quanto difere o comportamento dos filhotes FS (filhotes com sua própria mãe, sem competição com outra ninhada por espaço, comida, leite) do comportamento dos filhotes FPp (que mamaram exclusivamente de sua própria mãe em uma condição de possível competição com filhotes de outra mãe).

(2)

FPp e $F P(p+a)$ : comparamos os escores dos filhotes da condição FP que mamaram exclusivamente de suas mães (FPp) com os, da mesma condição, que mamaram e alomamaram [FP(p+a)]. Esta comparação tem um interesse especial porque através dela podese contrastar, no mesmo contexto, filhotes que usam estratégias diferentes: as diferenças na freqüência e na duração da amamentação, entre as estratégias, poderiam indicar a vantagem eventual, do ponto de vista do filhote, em obter recursos de duas fêmeas e não exclusivamente da própria mãe.

$F P p(p+a) \times F P a(p+a)$ : esta comparação também tem especial interesse porque pode mostrar o quanto o comportamento de um filhote que mama e alomama pode diferir quando dirigido à mãe ou à outra fêmea. As comparações, nesta parte da análise são feitas entre dados dos mesmos indivíduos (testes para dados pareados).

Nas análises estatísticas de freqüência e duração de amamentação ao longo das semanas, levamos apenas em conta os dados dos filhotes que tinham tido pelo menos um episódio de amamentação em cada semana examinada. É importante lembrar que os resultados descrevem a ontogênese e as diferenças dos episódios de amamentação (dirigidos à mãe e à outra fêmea), não levando em conta, como dado, a eventual ausência de amamentação. 
Nas comparações entre os dados das Etapas 1 e 2, usamos o algarismo 1 ou 2 para designar a etapa considerada: por exemplo, FS_1 e FS_2 são as siglas para os filhotes da condição FS, respectivamente na primeira e na segunda etapa do experimento. Nos gráficos, as curvas da Etapa 1 são sempre apresentadas em vermelho, e da Etapa 2 sempre em azul.

\section{Tamanho das ninhadas}

Na Etapa 1 não houve diferença significativa entre o tamanho das ninhadas na condição FS (10 pares de fêmeas) e FP (9 pares de fêmeas) (Student, t = 0,16, gl $=26, p>0,05)$, nem entre o tamanho das ninhadas na condição FS (10 pares de fêmeas) e FP (10 pares de fêmeas), (Student, $t=0,48, g l=28, p>0,05$ ). A ausência de diferenças significativas garante que diferenças eventuais entre FS e FP serão devidas ao contexto social, e não ao número médio de filhotes em cada caso.

Na Etapa 2 as ninhadas foram em média um pouco mais numerosas (cobaias albinas) do que na Etapa 1 (cobaias comuns). No caso de FS, os tamanhos médios das ninhadas foram 3 e 2,6 filhotes, respectivamente; no caso de FP, foram 3,1 e 2,6 filhotes, respectivamente. A diferença foi significativa no caso de FP (Student, $t=$ 2,04, $\mathrm{gl}=40, \mathrm{p}<0,05)$. Uma diferença no número de filhotes pode eventualmente acarretar diferenças no comportamento de amamentação (Künkele, 2000a).

\section{Ocorrência da aloamamentação}

A aloamamentação foi um fenômeno generalizado. Ocorreu (com pelo menos um filhote alomamando) em 8 dos 9 pares de fêmeas da Etapa 1 e em 10 dos 10 pares da Etapa 2. Na Etapa 1, 25 dos 46 filhotes alomamaram pelo menos uma vez (54,3 \%) e na Etapa 2, 40 dos 63 filhotes (63,5 \%). Houve aloamamentação tanto nas cobaias comuns como nas albinas na condição FP. A diferença entre as etapas não foi significativa $\left(\chi^{2}=0,3849, . g \mid 1, p>0,05\right)$.

Contudo, a aloamamentação mostrou-se um comportamento eventual (ver seção seguinte). Somente um filhote na Etapa 1 e outro na Etapa 2 alomamaram em todas as 4 semanas de observação pelo menos uma vez. Houve o caso de um 
filhote que alomamou somente na semana 4. O comportamento de alomamar foi alternado entre filhotes e semanas.

Freqüência de filhotes que mamaram e alomamaram

A porcentagem dos filhotes $F S, F P p, F P p(p+a)$ e $F P a(p+a)$ ao longo das quatro semanas de desenvolvimento, em ambas as etapas, estão representados nas Figuras 18 e 19.

Nota-se a constância do número de indivíduos que mamam da mãe [FS, FPp e $\operatorname{FPp}(p+a)$ ] ao longo das três primeiras semanas, com um decréscimo na quarta semana, quando se aproxima o desmame. A exceção é a condição FS_2 : nela não houve decréscimo do número de lactentes na quarta semana, uma possível indicação de um desenvolvimento mais lento. Não houve diferença significativa no número de lactentes ao longo das quatro semanas de desenvolvimento, nem na Etapa $1\left(\chi^{2}=1,44, \mathrm{gl}=6, \mathrm{p}>0,05\right)$, nem na Etapa $2\left(\chi^{2}=1,54, \mathrm{gl}=6, \mathrm{p}>0,05\right)$.

O resultado dos filhotes da condição $\mathrm{FPa}(\mathrm{p}+\mathrm{a})$ - isto é, o número de filhotes que, através das semanas, foi visto mamar pelo menos uma vez por semana na mãe alheia - é bem diferente dos outros: na primeira semana, o número destes filhotes que alomamaram se aproxima do número de filhotes que mamaram da mãe; nas semanas seguintes, esta freqüência diminuiu drasticamente (na Etapa 1 apenas um indivíduo ainda alomamava na quarta semana, e na Etapa 2 apenas 5 indivíduos alomamavam na quarta semana). 


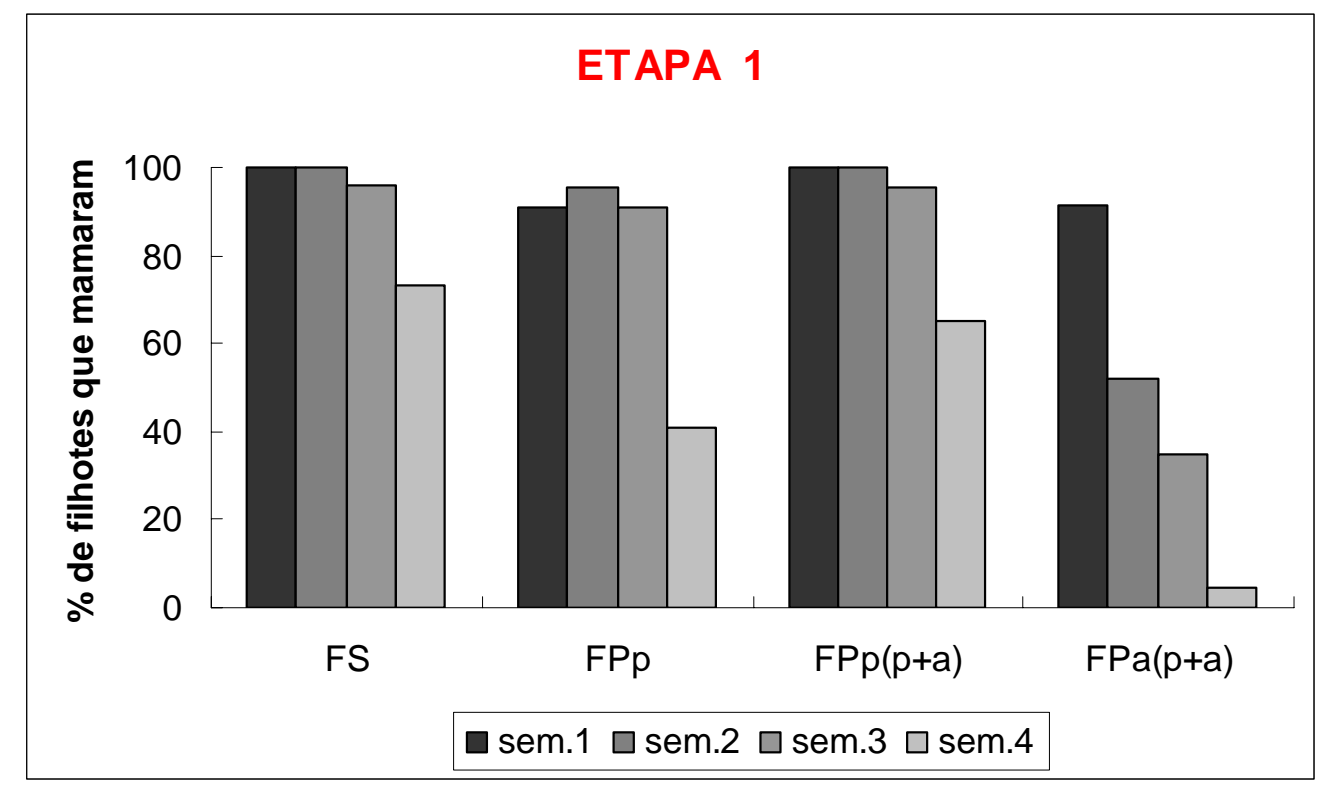

Figura 18: Porcentagem de indivíduos que mamaram [FS, FPp e $F P p(p+a)]$ e alomamaram $[\mathrm{Fpa}(\mathrm{p}+\mathrm{a})]$, na Etapas 1 , ao longo das 4 semanas de desenvolvimento.

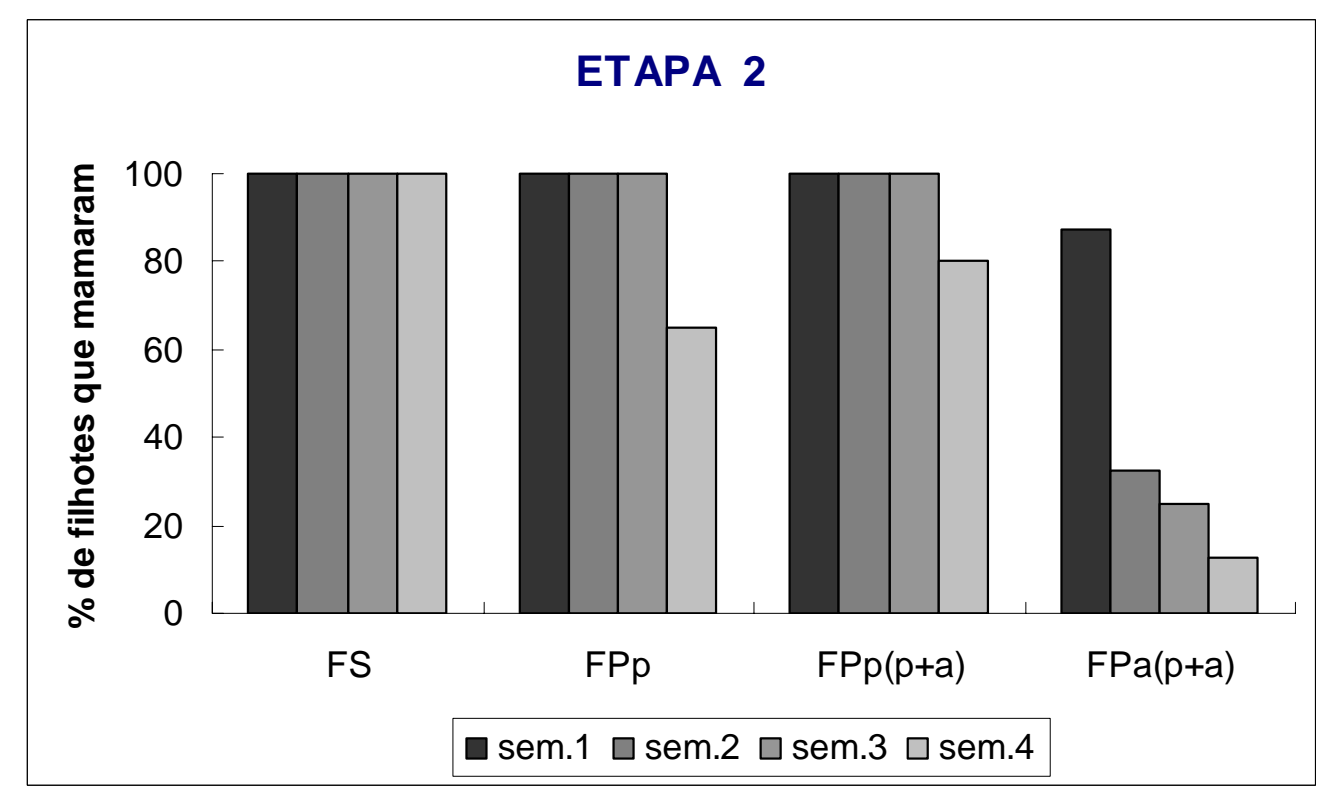

Figura 19: Porcentagem de indivíduos que mamaram [FS, FPp e FPp(p+a)] e alomamaram $[\mathrm{Fpa}(\mathrm{p}+\mathrm{a})]$, na Etapas 2, ao longo das 4 semanas de desenvolvimento.

A diferença entre os filhotes $\operatorname{FPa}(p+a)$ e $\operatorname{FPp}(p+a)$ foi significativa, tanto na Etapa $1\left(\chi^{2}=9,95, \mathrm{gl}=3, \mathrm{p}<0,01\right)$ como na Etapa $2\left(\chi^{2}=18,04, \mathrm{gl}=3, \mathrm{p}>\right.$ 0,001). Da figura e das análises, verifica-se que a aloamamentação atinge seu pico, 
em termos do número de filhotes que a praticam, na primeira semana de vida. Nas semanas seguintes, mais e mais filhotes desistem de buscar leite na outra fêmea.

Reciprocidade da aloamamentação

$\mathrm{Na}$ condição FP houve, levando em conta ambas as etapas (19 pares de fêmeas), 13 pares - 69 \% - de aloamamentação recíproca (em que pelo menos um filhote de cada fêmea alomamou junto à outra). Nove destes casos foram assimétricos (o número de filhotes de cada fêmea que alomamaram não era o mesmo) e 4 simétricos. Em 5 casos - $26 \%$ - houve aloamamentação unilateral (somente os filhotes de uma das fêmeas pareadas alomamaram) e em apenas um caso - $5 \%$ - houve ausência de aloamamentação, cada mãe cuidou com exclusividade dos seus filhotes. Existe, portanto, uma probabilidade razoável de que um ato de aloamamentação tenha contrapartida com um ato semelhante (não necessariamente simétrico) na outra fêmea. Há casos de unilateralidade a ser considerados, e também o caso mais raro que é de ausência de aloamamentação.

\section{DISTÂNCIA FÊMEA-FILHOTE}

A distância entre as fêmeas e os filhotes é um indicativo de um laço de apego e um fator capaz de influenciar a escolha do filhote pela mãe ou pela outra fêmea.

\section{FS $\times$ FPp}

A Figura 21 e as análises estatísticas (Tabela 1) indicam que houve uma diferença significativa entre a condição FS e a condição FPp na distância que os filhotes mantiveram da mãe própria. Em ambos os casos trata-se de filhotes que só se dirigiram à mãe própria para a obtenção de leite. Na condição FP, eles se mantêm, em média, mais longe dela do que na condição em que a família está isolada (FS). Esta diferença ocorreu nas três primeiras semanas e beira a significância na quarta, que é quando se supõe que os filhotes sejam mais 
independentes. Indica que uma situação de ninhadas simultâneas pode distanciar os filhotes de suas mães.

Não houve diferença entre réplicas quanto à distância fêmea-filhote, seja em FP ou FS. Curiosamente, a distância fêmea-filhote diminuiu da semana 1 para a semana 2 na Etapa 1, mantendo-se constante depois. Não houve mudanças significativas ao longo das semanas na Etapa 2.

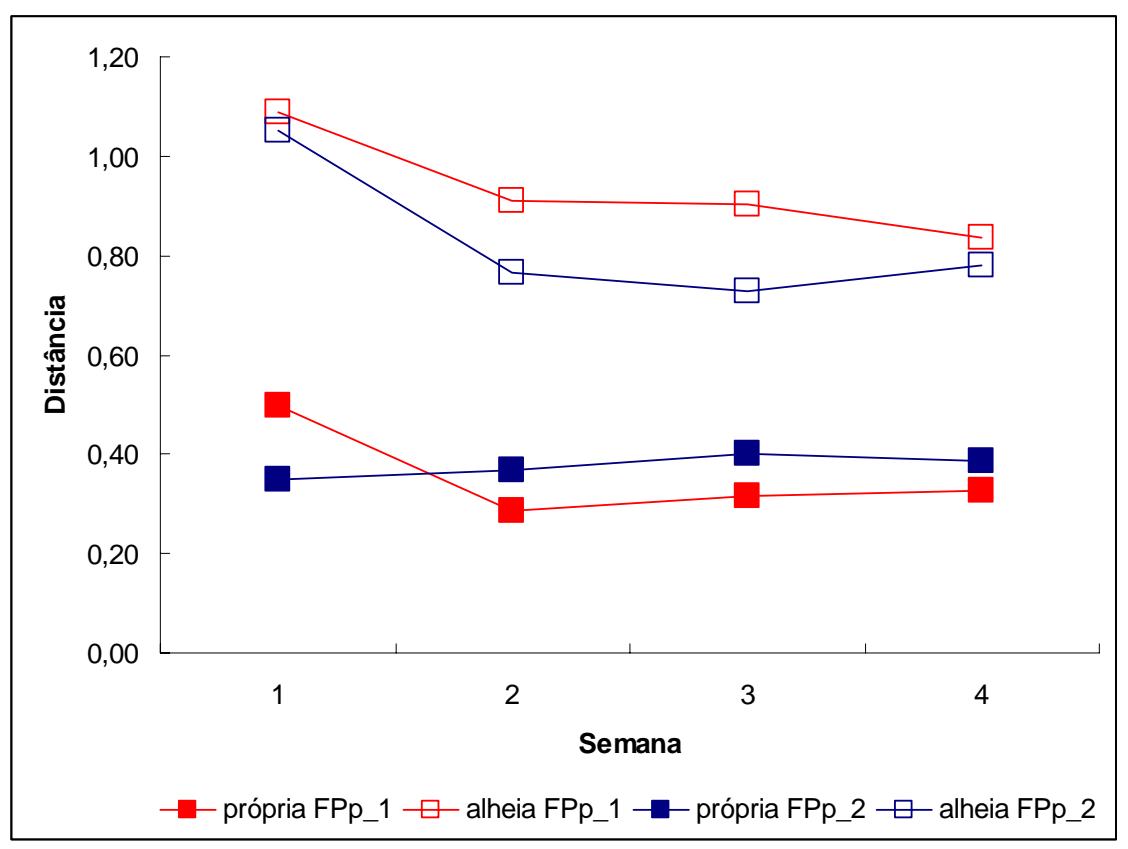

Figura 20: Distâncias médias dos filhotes FPp nas Etapas 1 e 2 em relação à mãe própria e mãe alheia ao longo das quatro semanas de observação. 


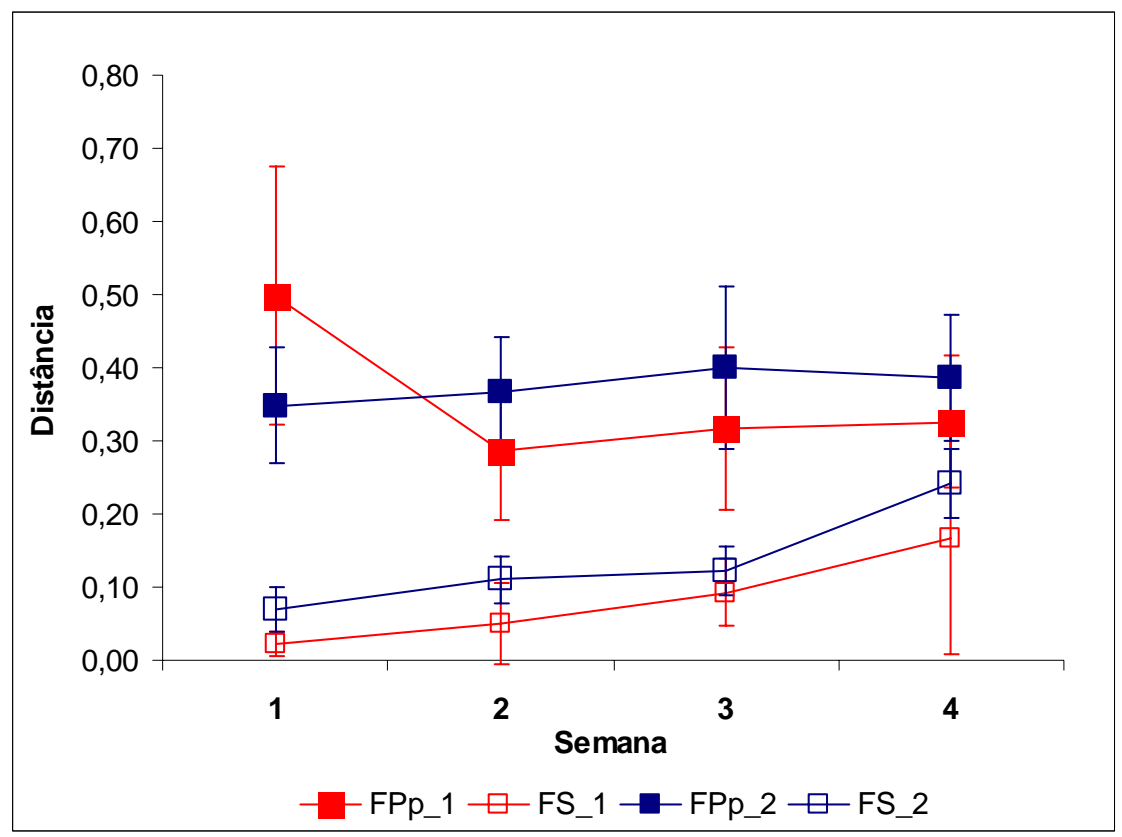

Figura 21: Distâncias médias dos filhotes FPp e FS das Etapas 1 e 2 em relação à mãe própria ao longo das quatro semanas de observação.

Tabela 1: Análise estatística de distância da mãe própria dos filhotes FS e FPp nas Etapas 1 e 2, ao longo das quatro semanas de observação.

\begin{tabular}{lc}
\hline Efeito & P \\
\hline GRUPO X SEMANA (ausência de interação, paralelismo) & 0,0008 \\
\hline EFEITO DE SEMANA - FPp_1 & 0,0008 \\
SEMANA 1 x SEMANA 2 & 0,0002 \\
SEMANA 2 x SEMANA 3 & 0,5947 \\
SEMANA 3 x SEMANA 4 & 0,8766 \\
\hline EFEITO DE SEMANA - FPp_2 & 0,8010 \\
\hline EFEITO DE SEMANA - FS_1 & 0,5416 \\
\hline EFEITO DE SEMANA - FS_2 & 0,0022 \\
SEMANA 1 x SEMANA 2 & 0,3901 \\
SEMANA 2 x SEMANA 3 & 0,8231 \\
SEMANA 3 x SEMANA 4 & 0,0112 \\
\hline SEMANA 1 & \\
FPp_1 x FPp_2 & 0,0139 \\
FPp_1 x FS_1 & $<0,0001$ \\
FPp_2 x FS_2 & 0,0001
\end{tabular}




\begin{tabular}{|c|c|}
\hline FS_1 $x$ FS_2 & 0,5810 \\
\hline \multicolumn{2}{|l|}{ SEMANA 2} \\
\hline FPp_1 x FPp_2 & 0,3857 \\
\hline FPp_1 x FS_1 & 0,0257 \\
\hline FPp_2 x FS_2 & 0,0004 \\
\hline FS_1 $1 \times$ FS_2 & 0,5080 \\
\hline \multicolumn{2}{|l|}{ SEMANA_3 } \\
\hline FPp_1 x FPp_2 & 0,3781 \\
\hline FPp_1 x FS_1 & 0,0341 \\
\hline FPp_2 x FS_2 & 0,0001 \\
\hline FS_1 $x$ FS_2 & 0,7054 \\
\hline \multicolumn{2}{|l|}{ SEMANA 4} \\
\hline FPp_1 x FPp_2 & 0,5757 \\
\hline FPp_1 x FS_1 & 0,1215 \\
\hline FPp_2 x FS_2 & 0,0581 \\
\hline FS_1 $1 \times$ FS_2 & 0,4367 \\
\hline
\end{tabular}

$F P p(p+a) \times F P a(p+a)$

A menor distância do filhote em relação à mãe do que à outra fêmea é um resultado praticamente geral. Na Etapa 1, a diferença entre a distância da mãe e da outra fêmea é significativa nas semanas 2, 3 e 4, e na Etapa 2, em todas as semanas. Este resultado indica de maneira clara que os filhotes de cobaia distinguem entre a sua mãe e a outra fêmea, e indica o seu apego pela mãe, expresso na procura de proximidade.

Na Etapa 1, contudo, a diferença entre a distância da mãe e da outra fêmea não foi significativa na primeira semana e nas semanas 2 e 3 a distância mantida em relação à mãe foi diminuindo, enquanto se mantinha igual em relação à outra fêmea. 


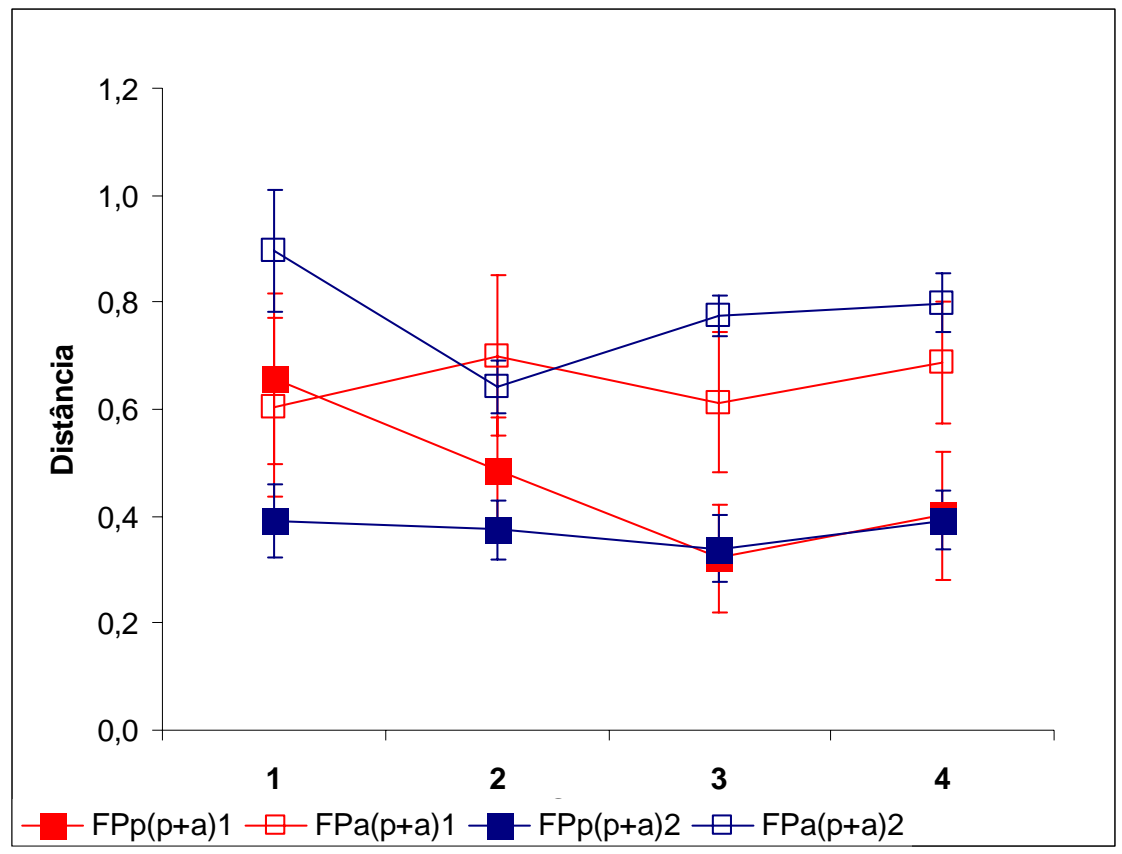

Figura 22: Distâncias médias dos filhotes $F P p(p+a)$ e $F P a(p+a)$ nas Etapas 1 e 2 em relação à mãe própria e mãe alheia ao longo das quatro semanas de observação. 
Tabela 2: Análise estatística de distância da mãe própria dos filhotes FS e FPp nas Etapas 1 e 2, ao longo das quatro semanas de observação.

\begin{tabular}{|c|c|}
\hline Efeito & $\mathbf{P}$ \\
\hline GRUPO X SEMANA (ausência de interação, paralelismo) & 0,0004 \\
\hline EFEITO DE SEMANA - FPa(p+a)_1 & 0,4449 \\
\hline EFEITO DE SEMANA - FPp(p+a)_1 & $<0,0001$ \\
\hline SEMANA $1 \times$ SEMANA 2 & 0,0223 \\
\hline SEMANA $2 \times$ SEMANA 3 & 0,0264 \\
\hline SEMANA 3 x SEMANA 4 & 0,2786 \\
\hline EFEITO DE SEMANA - FPa(p+a)_2 & 0,0003 \\
\hline SEMANA $1 \times$ SEMANA 2 & $<0,0001$ \\
\hline SEMANA $2 \times$ SEMANA 3 & 0,0242 \\
\hline SEMANA $3 \times$ SEMANA 4 & 0,6794 \\
\hline EFEITO DE SEMANA - FPp(p+a)_2 & 0,7784 \\
\hline \multicolumn{2}{|l|}{ SEMANA 1} \\
\hline$F P a(p+a) \_1 \times F P p(p+a) \_1$ & 0,4869 \\
\hline$F P a(p+a) \_1 \times F P a(p+a) \_2$ & 0,0004 \\
\hline$F P p(p+a) \_1 \times F P p(p+a) \_2$ & 0,0006 \\
\hline$F P a(p+a) \_2 x F P p(p+a) \_2$ & $<0,0001$ \\
\hline \multicolumn{2}{|l|}{ SEMANA 2} \\
\hline $\mathrm{FPa}(\mathrm{p}+\mathrm{a}) \_1 \times \mathrm{FPp}(\mathrm{p}+\mathrm{a}) \_1$ & 0,0041 \\
\hline $\mathrm{FPa}(\mathrm{p}+\mathrm{a}) \_1 \times \mathrm{FPa}(\mathrm{p}+\mathrm{a}) \_2$ & 0,4115 \\
\hline$F P p(p+a) \_1 \times F P p(p+a) \_2$ & 0,1334 \\
\hline $\mathrm{FPa}(\mathrm{p}+\mathrm{a}) \_2 \times \mathrm{FPp}(\mathrm{p}+\mathrm{a}) \_2$ & $<0,0001$ \\
\hline \multicolumn{2}{|l|}{ SEMANA 3} \\
\hline$F P a(p+a) \_1 \times F P p(p+a) \_1$ & $<0,0001$ \\
\hline $\mathrm{FPa}(\mathrm{p}+\mathrm{a}) \_1 \times \mathrm{FPa}(\mathrm{p}+\mathrm{a}) \_2$ & 0,0538 \\
\hline$F P p(p+a) \_1 \times F P p(p+a) \_2$ & 0,9105 \\
\hline $\mathrm{FPa}(\mathrm{p}+\mathrm{a}) \_2 \times \mathrm{FPp}(\mathrm{p}+\mathrm{a}) \_2$ & $<0,0001$ \\
\hline \multicolumn{2}{|l|}{ SEMANA 4} \\
\hline$F P a(p+a) \_1 \times F P p(p+a) \_1$ & 0,0001 \\
\hline $\mathrm{FPa}(\mathrm{p}+\mathrm{a}) \_1 \times \mathrm{FPa}(\mathrm{p}+\mathrm{a}) \_2$ & 0,1979 \\
\hline$F P p(p+a) \_1 \times F P p(p+a) \_2$ & 0,8262 \\
\hline $\mathrm{FPa}(\mathrm{p}+\mathrm{a}) \_2 \times \mathrm{FPp}(\mathrm{p}+\mathrm{a}) \_2$ & $<0,0001$ \\
\hline
\end{tabular}




\section{FS x FPp}

Freqüência média de amamentação

A freqüência média de amamentação se manteve constante nas semanas $1 \mathrm{e}$ 2, decrescendo em seguida, nas condições FS e FPp. O descréscimo era esperado e constitui uma característica do processo gradual de desligamento dos filhotes em relação à sua mãe, típica de mamíferos (Andriolo et al., 2001). Os resultados indicam que os filhotes se comportaram da mesma maneira numa condição em que estão sozinhos com a mãe e na condição de fêmeas pareadas. Houve uma freqüência maior de amamentações na Etapa 2 (cobaias albinas) do que na Etapa 1 (cobaias comuns) ao longo das semanas (Figura 23).

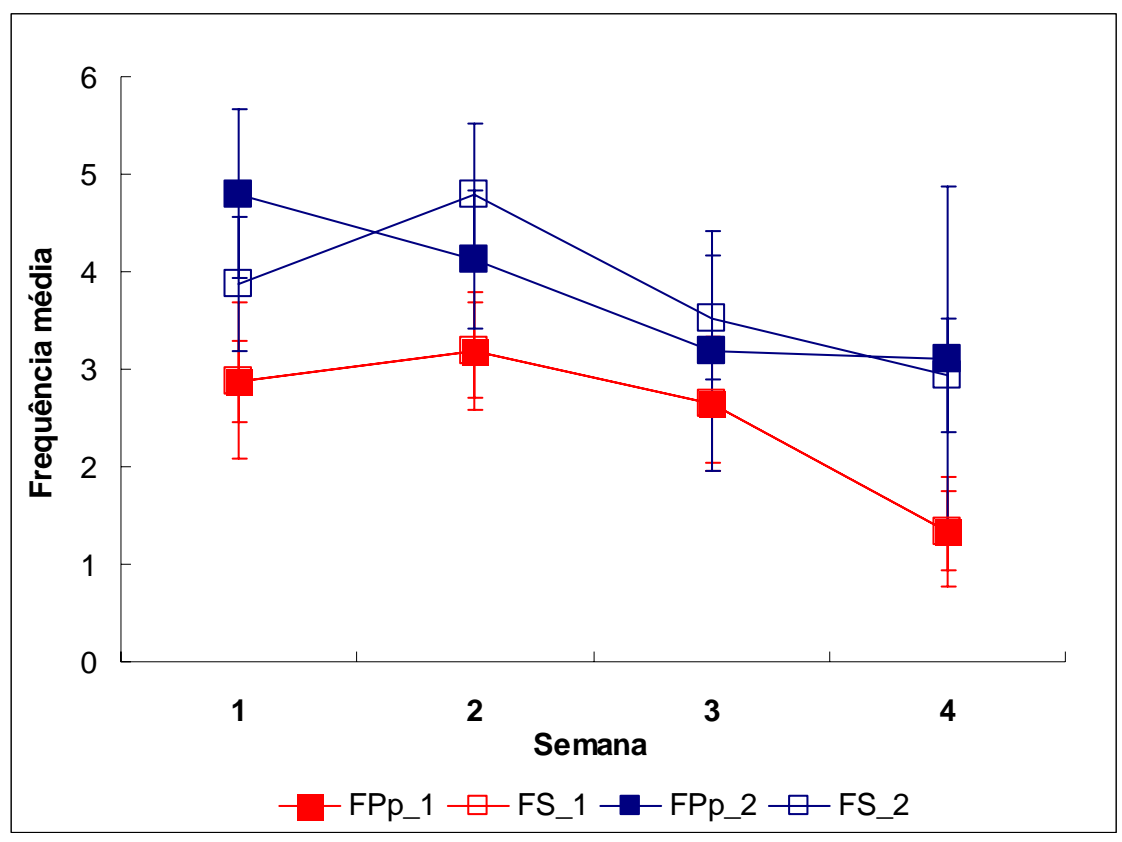

Figura 23: Freqüência média de amamentação dos filhotes FS e FPp nas Etapas 1 e 2, ao longo das quatro semanas de observação. 
Tabela 3: Análise estatística de freqüência média de amamentação dos filhotes FS e FPp das Etapas 1 e 2, ao longo das quatro semanas de observação.

\begin{tabular}{ll}
\hline Efeito & $\mathbf{p}$ \\
\hline GRUPO x SEMANA (ausência de interação, paralelismo das curvas) & 0,2160 \\
\hline EFEITO DE SEMANA & $<, 0001$ \\
SEMANA 1 x SEMANA 2 & 0,3045 \\
SEMANA 2 x SEMANA 3 & 0,0003 \\
SEMANA 3 x SEMANA 4 & 0,0009 \\
\hline EFEITO DE GRUPO & 0,0041 \\
FPp_1 x FPp_2 & 0,0040 \\
FPp_1 x FS_1 & 0,7437 \\
FPp_2 x FS_2 & 0,7971 \\
FS_1 x FS_2 & 0,0254 \\
\hline
\end{tabular}

Duração média de amamentação

A duração média de amamentação seguiu um curso semelhante ao da freqüência média durante o desenvolvimento dos filhotes, apresentando um decréscimo significativo a partir da segunda semana de vida, tanto em FS como em FPp (Figura 24).

$\mathrm{Na}$ Etapa 1, não houve diferença na duração média de amamentação entre as condições FS e FPp: neste caso, não fez diferença os filhotes estarem isolados com a mãe ou em um grupo maior. Na Etapa 2, contudo, os escores foram significativamente superiores no caso dos filhotes na condição FS. 


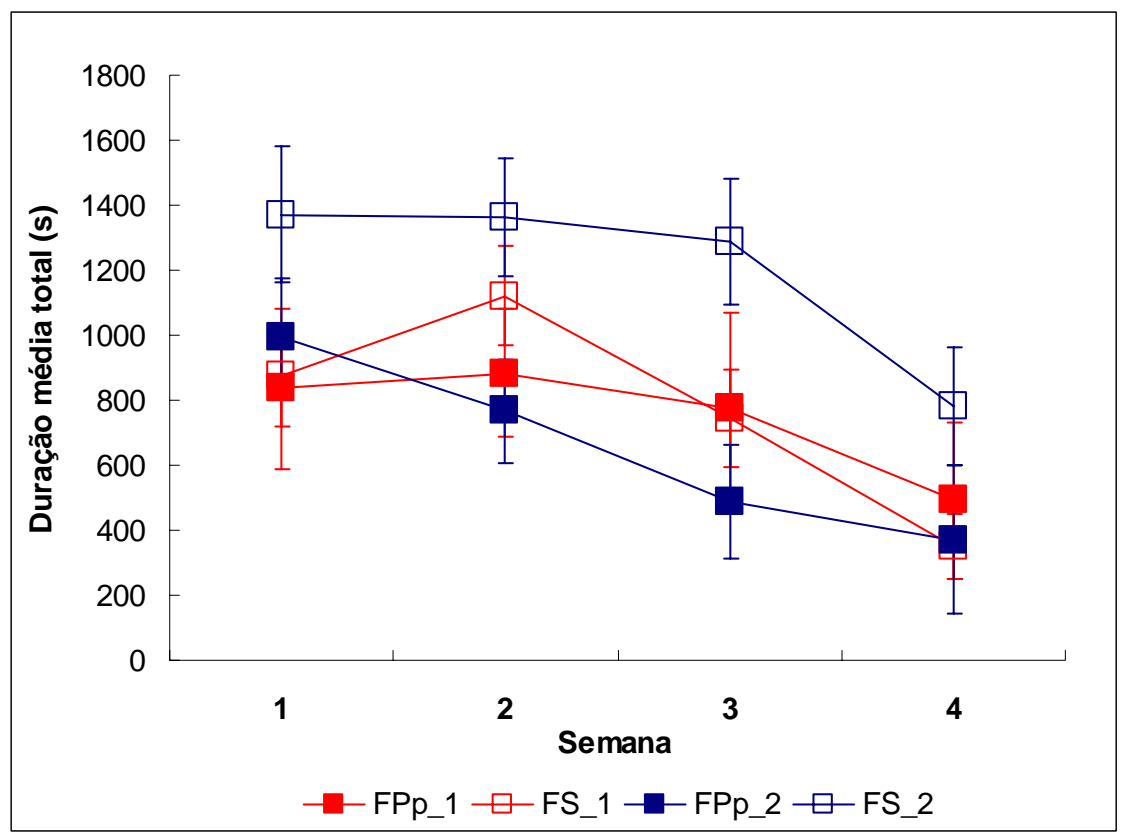

Figura 24: Duração média de amamentação dos filhotes FS e FPp nas Etapas 1 e 2, ao longo das quatro semanas de observação.

Tabela 4: Análise estatística de duração média de amamentação dos filhotes FS e FPp das Etapas 1 e 2, ao longo das quatro semanas de observação.

\begin{tabular}{lc}
\hline Efeito & $\mathbf{p}$ \\
\hline GRUPO x SEMANA (ausência de interação, paralelismo das curvas) & 0,0636 \\
\hline EFEITO DE SEMANA & $<0,0001$ \\
SEMANA1 x SEMANA2 & 0,7447 \\
SEMANA2 x SEMANA3 & 0,0003 \\
SEMANA3 x SEMANA4 & $<0,0001$ \\
\hline EFEITO DE GRUPO & 0,0002 \\
FPp1 x FPp2 & 0,7452 \\
FPp1 x FS1 & 0,4960 \\
FPp2 x FS2 & $<0,0001$ \\
FS1 x FS2 & 0,0031 \\
\hline
\end{tabular}

Duração média por episódio de amamentação

Na Etapa 1, a duração média por episódio de amamentação se manteve constante ao longo das semanas. Na Etapa 2, houve um decréscimo significativo na semana 4, no caso de FPp (Figura 25). 
Na Etapa 2, nota-se que a duração média por episódio é maior para os filhotes da condição FS do que para os da condição FPp. Esses filhotes FS parecem ter sido mais motivados para mamar, uma vez que tiveram maior duração total e maior duração por episódio de amamentação do que filhotes FPp.

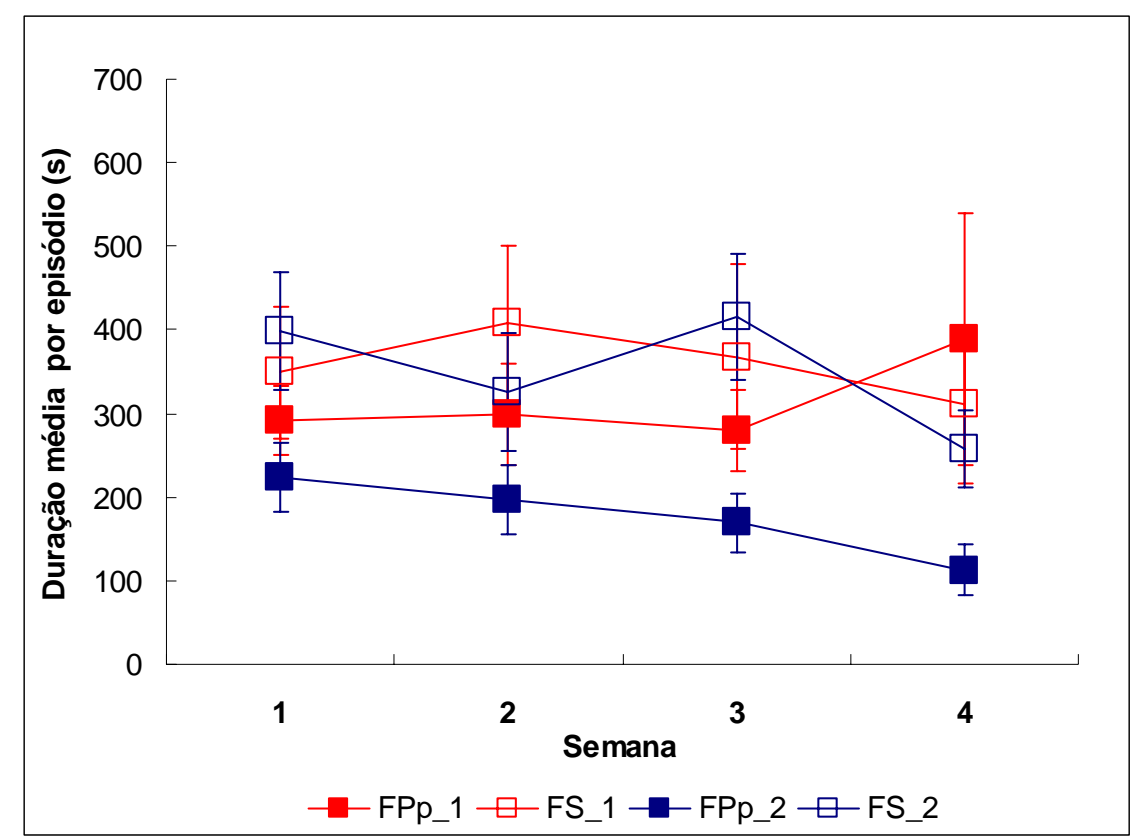

Figura 25: Duração média por episódio de amamentação dos filhotes FS e FPp nas Etapas 1 e 2, ao longo das quatro semanas de observação.

Tabela 5: Análise estatística de duração média por episódio de amamentação dos filhotes FS e FPp das Etapas 1 e 2, ao longo das quatro semanas de observação.

\begin{tabular}{ll}
\hline Efeito & $\mathbf{P}$ \\
\hline GRUPO X SEMANA (ausência de interação, paralelismo) & 0,0192 \\
\hline EFEITO DE SEMANA - FPp_1 & 0,5100 \\
\hline EFEITO DE SEMANA - FPp_2 & 0,1375 \\
\hline EFEITO DE SEMANA - FS_1 & 0,2082 \\
\hline EFEITO DE SEMANA - FS_2 & 0,0002 \\
SEMANA 1 x SEMANA 2 & 0,0747 \\
SEMANA 2 x SEMANA 3 & 0,0271 \\
SEMANA 3 x SEMANA 4 & $<, 0001$ \\
\hline SEMANA 1 & \\
FPp_1 x FPp_2 & 0,2292 \\
FPp_1 x FS_1 & 0,3445 \\
FPp_2 x FS_2 & 0,0011 \\
FS_1 x FS_2 & 0,3162 \\
\hline SEMANA 2 & \\
FPp_1 x FPp_2 & 0,0734
\end{tabular}




\begin{tabular}{|c|c|}
\hline FPp_1 x FS_1 & 0,0559 \\
\hline FPp_2 x FS_2 & 0,0162 \\
\hline $\mathrm{FS} \overline{1} \times \mathrm{FS} \overline{2}$ & 0,1340 \\
\hline \multicolumn{2}{|l|}{ SEMANA 3} \\
\hline FPp_1 x FPp_2 & 0,0607 \\
\hline FPp_1 x FS_1 & 0,1119 \\
\hline FPp_2 $\times$ FS_2 & $<, 0001$ \\
\hline $\mathrm{FS} \_\overline{1} \times \mathrm{FS} \_\overline{2}$ & 0,3531 \\
\hline \multicolumn{2}{|l|}{ SEMANA 4} \\
\hline FPp_1 x FPp_2 & 0,0003 \\
\hline FPp_1 $x$ FS_1 & 0,3517 \\
\hline FPp_2 $x$ FS_2 & 0,0096 \\
\hline $\mathrm{FS} \overline{1} \times \mathrm{FS} \overline{2}$ & 0,3934 \\
\hline
\end{tabular}

\section{FPp x FP(p+a)}

Freqüência média de amamentação

Um resultado interessante, nesta comparação, foi a ausência de diferenças significativas entre FPp e FP( $p+a)$, em todas as semanas. Um filhote que mamou e alomamou não aumentou sua freqüência de amamentação em relação a outro que se dirigiu exclusivamente para a própria mãe e isso vale inclusive para a primeira semana - em que sabemos que houve maior aloamamentação, em termos do número de filhotes envolvidos.

A freqüência média foi significativamente maior na Etapa 2 do que na Etapa 1. 


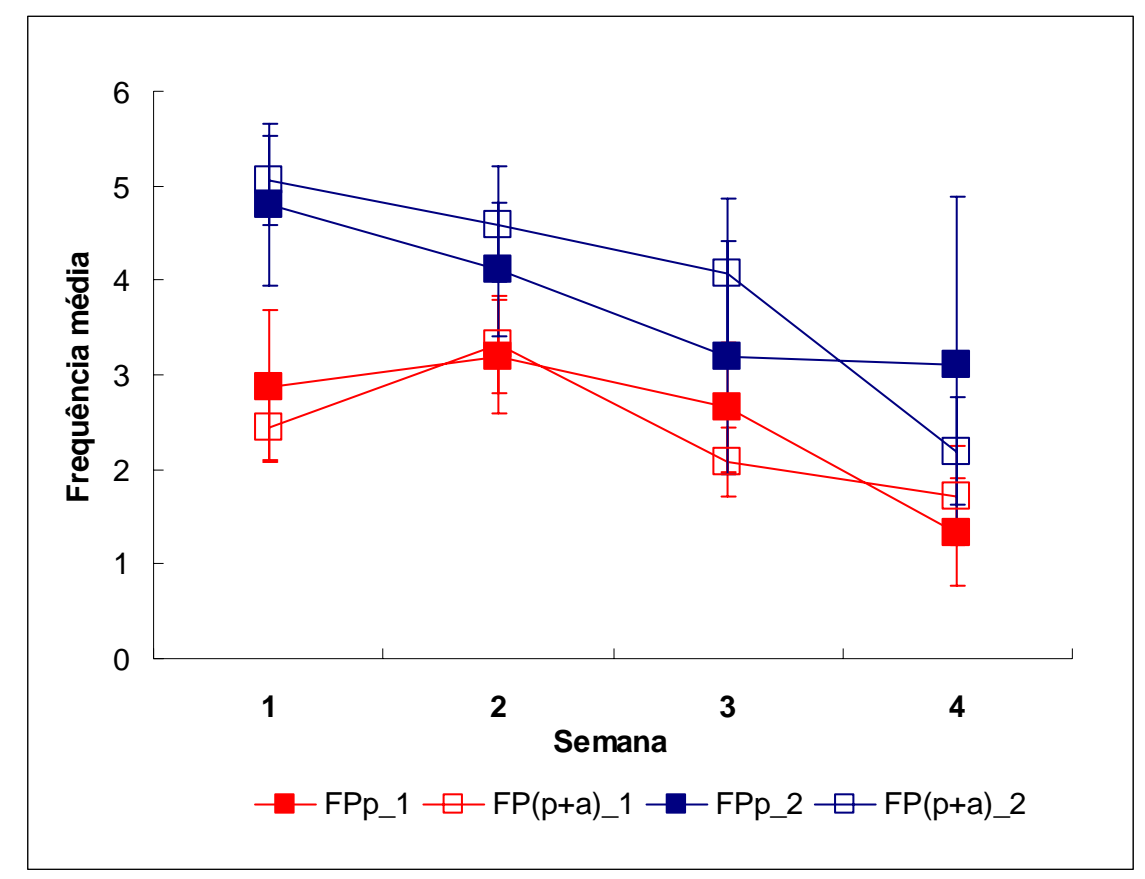

Figura 26: Freqüência média de amamentação e/ou aloamamentação dos filhotes da condição FPp e FP(p+a) nas Etapas 1 e 2, ao longo das quatro semanas de observação.

Tabela 6: Análise estatística de freqüência Média de amamentação e/ou aloamamentação dos filhotes FPp e FP( $p+a)$ nas Etapas 1 e 2, ao longo das quatro semanas de observação.

\begin{tabular}{lc}
\hline Efeito & $\mathbf{p}$ \\
\hline GRUPO x SEMANA (ausência de interação, paralelismo das curvas) & 0,2071 \\
\hline EFEITO DE SEMANA & $<0,0001$ \\
SEMANA 1 x SEMANA 2 & 0,9398 \\
SEMANA 2 x SEMANA 3 & 0,0003 \\
SEMANA 3 x SEMANA 4 & 0,0002 \\
\hline EFEITO DE GRUPO & 0,0043 \\
FP(p+a)_1 x FP(p+a)_2 & 0,0035 \\
FP(p+a)_1 x FPp_1 & 0,8132 \\
FP(p+a)_2 x FPp_2 & 0,3511 \\
FPp_1 x FPp_2 & 0,0007 \\
\hline
\end{tabular}

Duração média total de amamentação

As curvas relativas às condições $F P p$ e $F P(p+a)$ são semelhantes nas duas etapas, decrescendo significativamente ao longo das quatro semanas de observação. Nota-se, contudo, a ocorrência de um aumento significativo da semana 1 para a semana 2 no caso dos filhotes $F P(p+a) \_1$. 
Contrariamente ao caso das freqüências médias, não houve diferença entre etapas. Vê-se então que as cobaias albinas (Etapa 2) tiveram maior freqüência de amamentação do que as cobaias comuns (Etapa 1), mas uma duração total de amamentação semelhante, o que leva a prever uma menor duração média por episódio na Etapa 2.

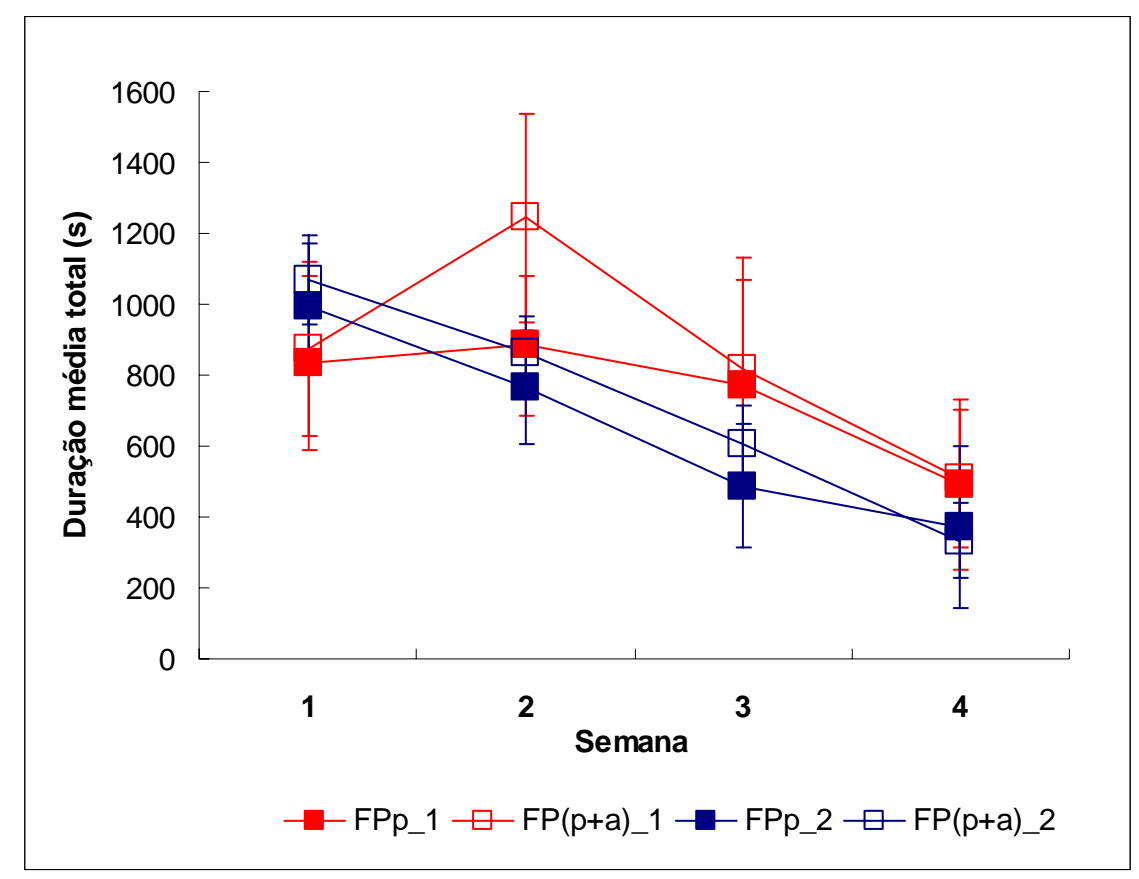

Figura 27: Duração média total de amamentação e/ou aloamamentação dos filhotes FPp e FP(p+a) nas Etapas 1 e 2, ao longo das quatro semanas de observação. 
Tabela 7: Análise estatística de duração média total dos filhotes FPp e FP(p+a) nas Etapas 1 e 2, ao longo das quatro semanas de observação.

\begin{tabular}{lc}
\hline Efeito & P \\
\hline GRUPO X SEMANA (ausência de interação, paralelismo) & 0,0008 \\
\hline EFEITO DE SEMANA - FP(p+a)_1 & $<0,0001$ \\
SEMANA 1 x SEMANA 2 & 0,0008 \\
SEMANA 2 x SEMANA 3 & $<0,0001$ \\
SEMANA 3 x SEMANA 4 & 0,0015 \\
\hline EFEITO DE SEMANA - FP(p+a)_2 & $<0,0001$ \\
SEMANA 1 x SEMANA 2 & 0,0173 \\
SEMANA 2 x SEMANA 3 & 0,0032 \\
SEMANA 3 x SEMANA 4 & 0,0022 \\
\hline EFEITO DE SEMANA - FPp_1 & 0,0165 \\
SEMANA 1 x SEMANA 2 & 0,6175 \\
SEMANA 2 x SEMANA 3 & 0,3004 \\
SEMANA 3 x SEMANA 4 & 0,0209 \\
\hline EFEITO DE SEMANA - FPp_2 & $<0,0001$ \\
SEMANA 1 x SEMANA 2 & 0,0490 \\
SEMANA 2 x SEMANA 3 & 0,0150 \\
SEMANA 3 x SEMANA 4 & 0,1251 \\
\hline SEMANA 1 & \\
FP(p+a)_1 x FP(p+a)_2 & 0,2280 \\
FP(p+a)_1 x FPp_1 & 0,9436 \\
FP(p+a)_2 x FPp_2 & 0,8870 \\
FPp_1 x FPp_2 & 0,2119 \\
\hline SEMANA 2 & \\
FP(p+a)_1 x FP(p+a)_2 & 0,0387 \\
FP(p+a)_1 x FPp_1 & 0,0114 \\
FP(p+a)_2 x FPp_2 & 0,9776 \\
FPp_1 x FPp_2 & 0,7894 \\
\hline SEMANA 3 & \\
FP(p+a)_1 x FP(p+a)_2 & 0,3011 \\
FP(p+a)_1 x FPp_1 & 0,9710 \\
FP(p+a)_2 x FPp_2 & 0,8180 \\
FPp_1 x FPp_2 & 0,2835 \\
\hline SEMANA 4 & \\
FP(p+a)_1 x FP(p+a)_2 & 0,7398 \\
FP(p+a)_1 x FPp_1 & 0,8794 \\
FP(p+a)_2 x FPp_2 & 0,6605 \\
FPp_1 x FPp_2 & 0,8811 \\
\hline & \\
&
\end{tabular}


Duração média por episódio de amamentação

A duração média por episódio se manteve praticamente constante ao longo das semanas (salvo decréscimo da semana 2 para a semana 3), não havendo diferença significativa entre $\mathrm{FPp}$ e $\mathrm{FP}(\mathrm{p}+\mathrm{a})$. As durações médias por episódio, como indicado acima, foram menores na Etapa 2 do que na Etapa 1.

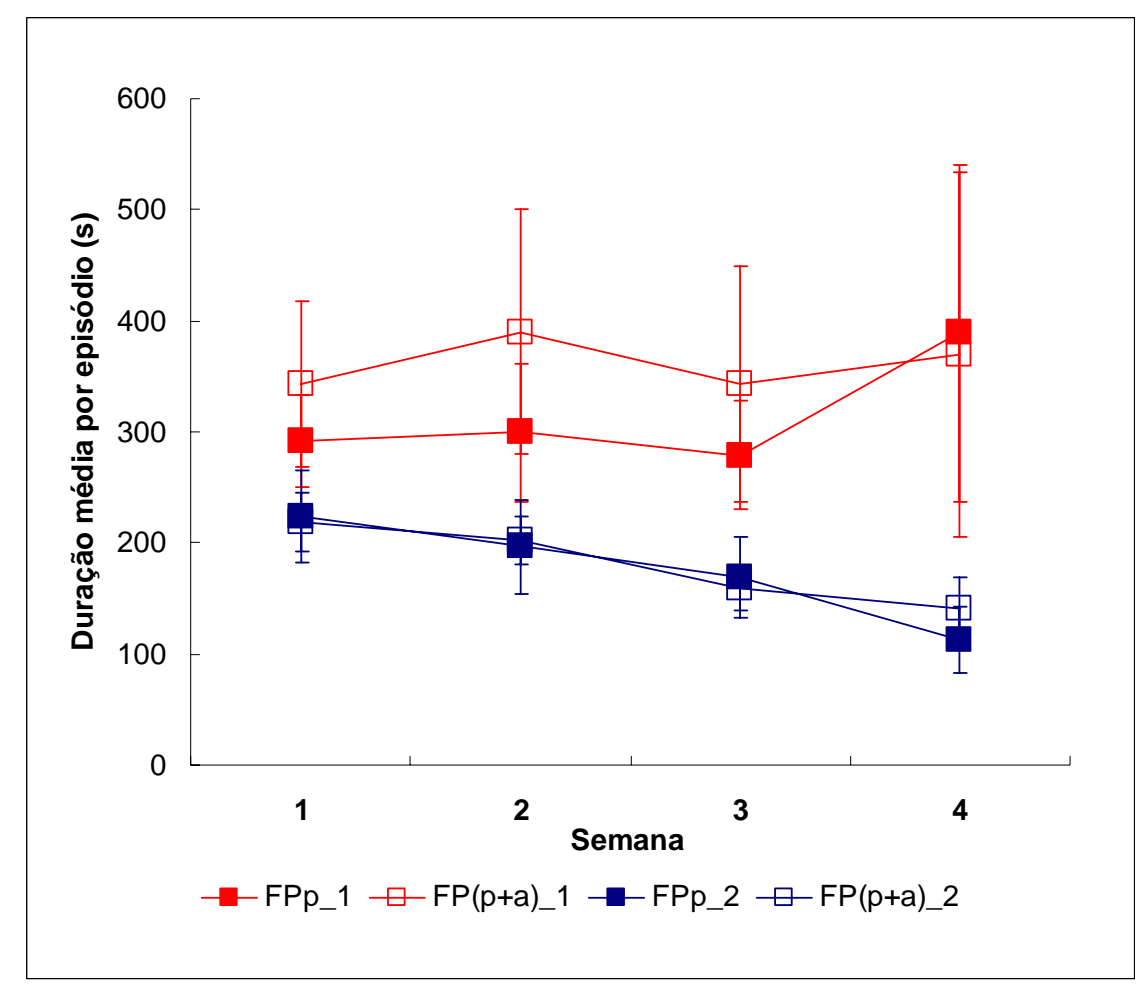

Figura 28: Duração média por episódio de amamentação dos filhotes FPp e $F P(p+a)$ nas Etapas 1 e 2, ao longo das quatro semanas de observação.

Tabela 8: Análise estatística de duração média por episódio de amamentação e/ou aloamamentação dos filhotes FPp e FP(p+a) nas Etapas 1 e 2, ao longo das quatro semanas de observação.

\begin{tabular}{lc}
\hline Efeito & $\mathbf{P}$ \\
\hline GRUPO X SEMANA (ausência de interação, paralelismo) & 0,1034 \\
\hline EFEITO DE SEMANA & 0,0306 \\
SEMANA1 x SEMANA2 & 0,8813 \\
SEMANA2 x SEMANA3 & 0,0300 \\
SEMANA3 x SEMANA4 & 0,7266 \\
\hline EFEITO DE GRUPO & 0,0189 \\
FPp+a1 x FPp+a2 & 0,0016 \\
FPp+a1 x FPp1 & 0,4373 \\
FPp+a2 x FPp2 & 0,8301 \\
FPp1 x FPp2 & 0,0090 \\
\hline
\end{tabular}




\section{Freqüência Média de Amamentação}

Em ambas as etapas os filhotes $\mathrm{FP}(\mathrm{p}+\mathrm{a})$ tiveram uma maior freqüência de amamentação junto à própria mãe do que à outra fêmea nas semanas 1, 2 e 3, mas não na semana 4. Este resultado se coaduna com os dados da distância fêmeafilhote e mostra que ao apego do filhote se junta uma tendência marcante a selecionar a própria mãe para mamar.

Nota-se na Figura 29 que a freqüência média de aloamamentação [FPa(p+a)] se manteve baixa e constante ao longo das semanas, enquanto que a de amamentação na própria mãe tendeu a diminuir no final do período. Como em comparações anteriores nota-se que os filhotes da Etapa 2 buscaram sua mãe para mamar com maior freqüência do que os filhotes da Etapa 1.

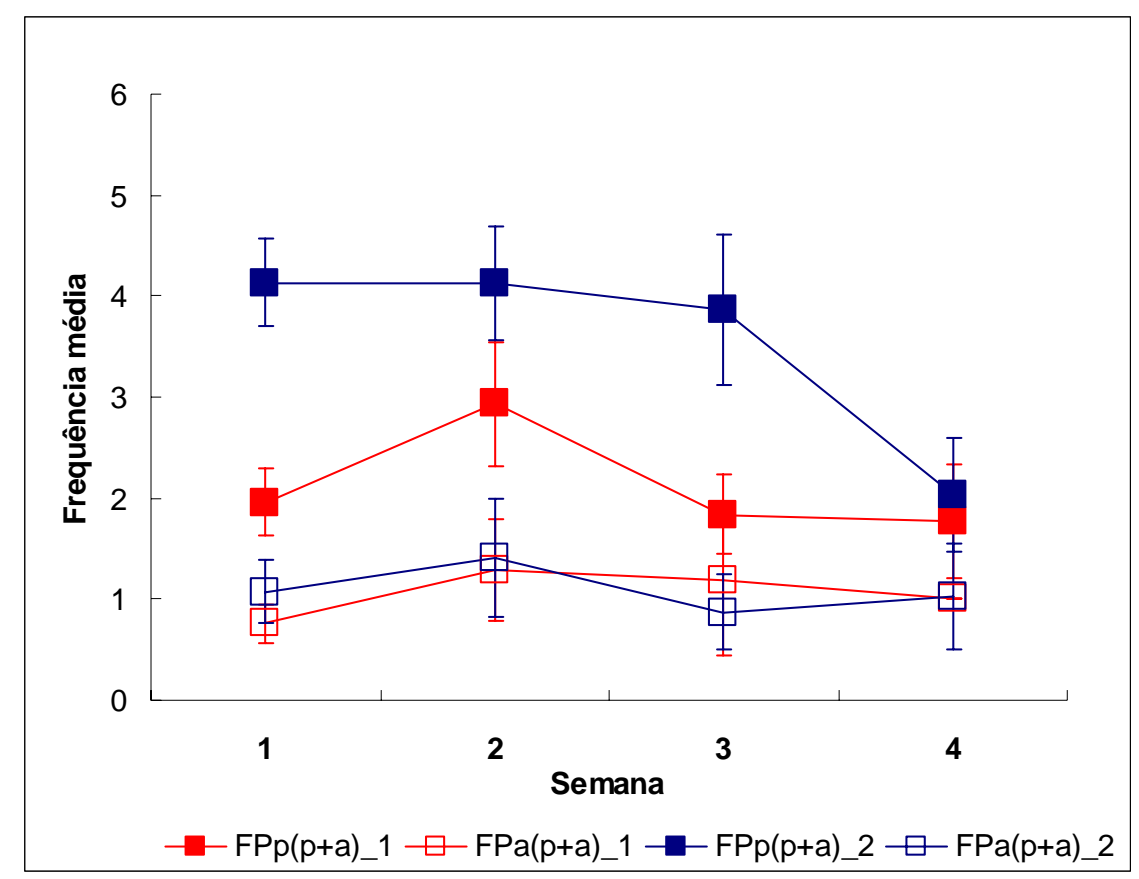

Figura 29: Freqüência média de amamentação $[F P p(p+a)]$ e aloamamentação $[\mathrm{FPa}(\mathrm{p}+\mathrm{a})]$, nas Etapas 1 e 2, ao longo das quatro semanas de observação. 
Tabela 9: Análise estatística de freqüência média de amamentação $F P p(p+a)$ e aloamamentação $\mathrm{FPa}(\mathrm{p}+\mathrm{a})$ nas Etapas 1 e 2, ao longo das quatro semanas de observação.

\begin{tabular}{|c|c|}
\hline Efeito & $\mathbf{p}$ \\
\hline GRUPO X SEMANA (ausência de interação, paralelismo) & 0,0022 \\
\hline EFEITO DE SEMANA - FPa $(p+a) \_1$ & 0,8324 \\
\hline EFEITO DE SEMANA - FPp(p+a) 1 & 0,0134 \\
\hline SEMANA 1 x SEMANA 2 & 0,0110 \\
\hline SEMANA 2 x SEMANA 3 & 0,0064 \\
\hline SEMANA $3 \times$ SEMANA 4 & 0,8979 \\
\hline EFEITO DE SEMANA - FPa $(p+a) \_2$ & 0,6983 \\
\hline EFEITO DE SEMANA - FPp(p+a)_2 & $<0,0001$ \\
\hline SEMANA 1 x SEMANA 2 & 0,9945 \\
\hline SEMANA $2 \times$ SEMANA 3 & 0,3683 \\
\hline SEMANA $3 \times$ SEMANA 4 & $<0,0001$ \\
\hline \multicolumn{2}{|l|}{ SEMANA 1} \\
\hline $\mathrm{FPa}(\mathrm{p}+\mathrm{a}) \_1 \times \mathrm{FPp}(\mathrm{p}+\mathrm{a}) \_1$ & 0,0043 \\
\hline $\mathrm{FPa}(\mathrm{p}+\mathrm{a}) \_1 \times \mathrm{FPa}(\mathrm{p}+\mathrm{a}) \_2$ & 0,7954 \\
\hline$F P p(p+a) \_1 \times F P p(p+a) \_2$ & $<0,0001$ \\
\hline$F P a(p+a) \_2 \times F P p(p+a) \_2$ & $<0,0001$ \\
\hline \multicolumn{2}{|l|}{ SEMANA 2} \\
\hline $\mathrm{FPa}(\mathrm{p}+\mathrm{a}) \_1 \times \mathrm{FPp}(\mathrm{p}+\mathrm{a}) \_1$ & 0,0003 \\
\hline $\mathrm{FPa}(\mathrm{p}+\mathrm{a}) \_1 \times \mathrm{FPa}(\mathrm{p}+\mathrm{a}) \_2$ & 0,9446 \\
\hline$F P p(p+a) 1 \times F P p(p+a) 2$ & 0,0208 \\
\hline $\mathrm{FPa}(\mathrm{p}+\mathrm{a}) \_2 \times \mathrm{FPp}(\mathrm{p}+\mathrm{a}) \_2$ & $<0,0001$ \\
\hline \multicolumn{2}{|l|}{ SEMANA 3} \\
\hline $\mathrm{FPa}(p+a) \_1 \times \mathrm{FPp}(\mathrm{p}+\mathrm{a}) \_1$ & 0,1792 \\
\hline$F P a(p+a) \_1 \times F P a(p+a) \_2$ & 0,5030 \\
\hline$F P p(p+a) \_1 \times F P p(p+a) \_2$ & $<0,0001$ \\
\hline $\mathrm{FPa}(\mathrm{p}+\mathrm{a}) \_2 \times \mathrm{FPp}(\mathrm{p}+\mathrm{a}) \_2$ & $<0,0001$ \\
\hline \multicolumn{2}{|l|}{ SEMANA 4} \\
\hline $\mathrm{FPa}(p+a) \_1 \times F P p(p+a) \_1$ & 0,4197 \\
\hline $\mathrm{FPa}(\mathrm{p}+\mathrm{a}) \_1 \times \mathrm{FPa}(\mathrm{p}+\mathrm{a}) \_2$ & 0,6616 \\
\hline $\operatorname{FPp}(p+a) \_1 \times F P p(p+a) \_2$ & 0,9733 \\
\hline $\mathrm{FPa}(\mathrm{p}+\mathrm{a}) \_2 \times \mathrm{FPp}(\mathrm{p}+\mathrm{a}) \_2$ & 0,4350 \\
\hline
\end{tabular}

Duração média de amamentação

Os dados são semelhantes aos dados de freqüência média de amamentação. Em ambas as etapas (não houve praticamente diferença entre etapas), os filhotes tiveram uma duração maior de amamentação junto à mãe do que à outra fêmea. Houve decréscimo na duração da amamentação com a mãe [FPp $(\mathrm{p}+\mathrm{a})]$ a partir da segunda semana (nota-se, contudo, um aumento da semana 1 para a semana 2), mas uma manutenção da duração da aloamamentação $[\mathrm{FPa}(\mathrm{p}+\mathrm{a})]$. A aloamamentação teve um decurso relativamente constante ao longo das semanas, 
mas como foi visto mais acima, o número de filhotes que alomamaram diminuiu drasticamente da semana 1 em diante.

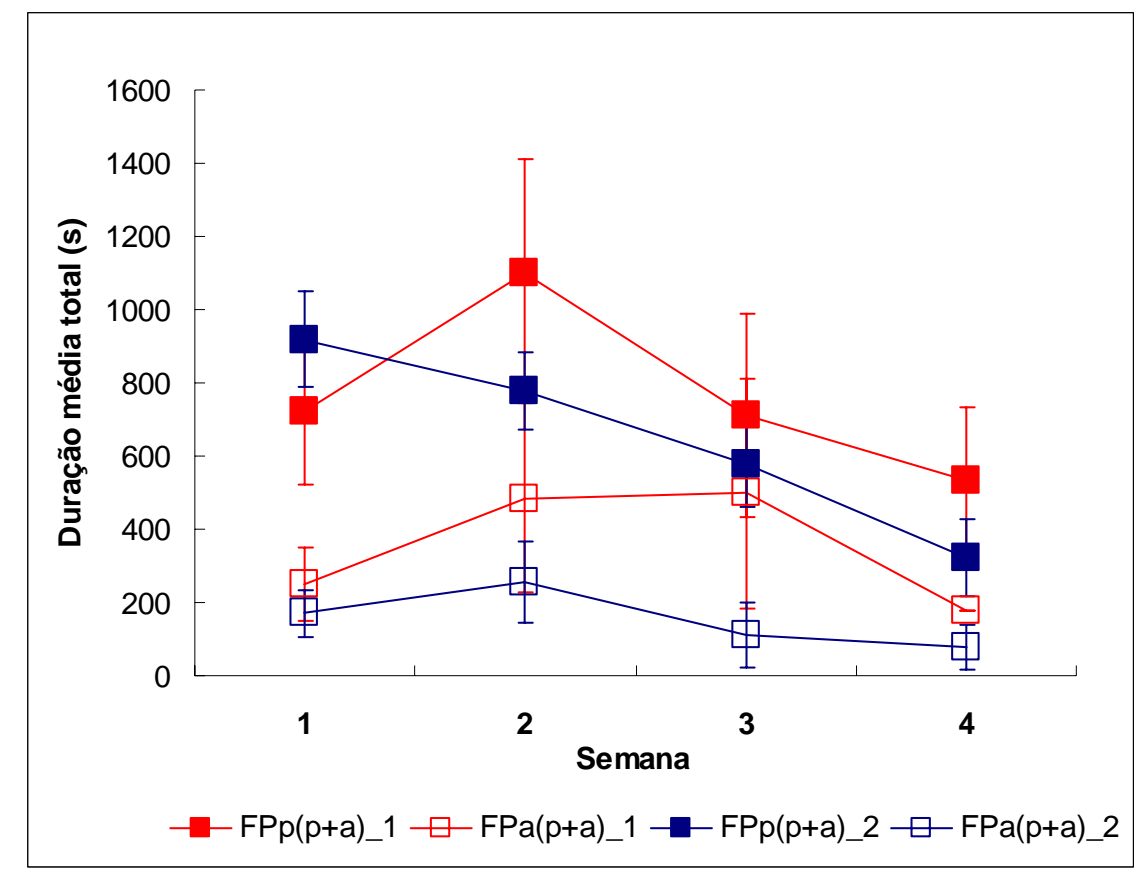

Figura 30: Duração média total de amamentação [FPp(p+a)] e aloamamentação $[\mathrm{FPa}(\mathrm{p}+\mathrm{a})]$ para os filhotes do grupo $\mathrm{FP}(\mathrm{p}+\mathrm{a})$, nas Etapas 1 e 2, ao longo das quatro semanas de observação.

Tabela 10: Análise estatística de duração média total de amamentação $F P p(p+a)$ e aloamamentação $\mathrm{FPa}(\mathrm{p}+\mathrm{a})$ dos filhotes nas Etapas 1 e 2, ao longo das quatro semanas de observação.

\begin{tabular}{lc}
\hline Efeito & $\mathbf{p}$ \\
\hline GRUPO X SEMANA (ausência de interação, paralelismo) & 0,0007 \\
\hline EFEITO DE SEMANA - FPa(p+a)_1 & 0,2064 \\
\hline EFEITO DE SEMANA - FPp(p+a)_1 & $<0,0001$ \\
SEMANA 1 x SEMANA 2 & 0,0003 \\
SEMANA 2 x SEMANA 3 & 0,0002 \\
SEMANA 3 x SEMANA 4 & 0,0563 \\
\hline EFEITO DE SEMANA - FPa(p+a)_2 & 0,7614 \\
\hline EFEITO DE SEMANA - FPp(p+a)_2 & $<0,0001$ \\
SEMANA 1 x SEMANA 2 & 0,0804 \\
SEMANA 2 x SEMANA 3 & 0,0127 \\
SEMANA 3 x SEMANA 4 & 0,0023 \\
\hline SEMANA 1 & \\
FPa(p+a)_1 x FPp(p+a)_1 & $<0,0001$ \\
FPa(p+a)_1 x FPa(p+a)_2 & 0,4934 \\
FPp(p+a)_1 x FPp(p+a)_2 & 0,2897 \\
FPa(p+a)_2 x FPp(p+a)_2 & $<0,0001$ \\
\hline SEMANA 2 &
\end{tabular}




\begin{tabular}{|c|c|}
\hline $\mathrm{FPa}(\mathrm{p}+\mathrm{a}) \_1 \times \mathrm{FPp}(\mathrm{p}+\mathrm{a}) \_1$ & $<0,0001$ \\
\hline $\mathrm{FPa}(\mathrm{p}+\mathrm{a}) \_1 \times \mathrm{FPa}(\mathrm{p}+\mathrm{a}) \_2$ & 0,1598 \\
\hline $\mathrm{FPp}(\mathrm{p}+\mathrm{a}) \_1 \times \mathrm{FPp}(\mathrm{p}+\mathrm{a}) \_2$ & 0,0138 \\
\hline $\mathrm{FPa}(\mathrm{p}+\mathrm{a}) \_2 \times \mathrm{FPp}(\mathrm{p}+\mathrm{a}) \_2$ & $<0,0001$ \\
\hline \multicolumn{2}{|l|}{ SEMANA 3} \\
\hline $\mathrm{FPa}(\mathrm{p}+\mathrm{a}) \_1 \times \mathrm{FPp}(\mathrm{p}+\mathrm{a}) \_1$ & 0,0788 \\
\hline $\mathrm{FPa}(\mathrm{p}+\mathrm{a}) \_1 \times \mathrm{FPa}(\mathrm{p}+\mathrm{a}) \_2$ & 0,0582 \\
\hline$F P p(p+a) \_1 \times F P p(p+a) \_2$ & 0,2467 \\
\hline$F p a(p+a) 22 \times F P p(p+a) 2$ & 0,0002 \\
\hline \multicolumn{2}{|l|}{ SEMANA 4} \\
\hline $\mathrm{FPa}(\mathrm{p}+\mathrm{a}) \_1 \times \mathrm{FPp}(\mathrm{p}+\mathrm{a}) \_1$ & 0,3325 \\
\hline $\mathrm{FPa}(\mathrm{p}+\mathrm{a}) \_1 \times \mathrm{FPa}(\mathrm{p}+\mathrm{a}) \_2$ & 0,9881 \\
\hline$F P p(p+a) \_1 \times F P p(p+a) \_2$ & 0,2104 \\
\hline $\mathrm{FPa}(\mathrm{p}+\mathrm{a}) \_2 \times \mathrm{FPp}(\mathrm{p}+\mathrm{a}) \_2$ & 0,3200 \\
\hline
\end{tabular}

Duração Média por Episódio de Amamentação

A duração média por episódio de amamentação se manteve constante ao longo das semanas. Não houve diferença significativa entre $F P a(p+a)$ e $F P p(p+a)$, uma indicação de que as fêmeas cobaias (ou os filhotes) não interrompem um surto de maneira diferencial no caso de uma dupla fêmea-filhote próprio e de uma dupla fêmea-filhote alheio. Se houvesse essa diferença poderíamos pensar em um controle seletivo (filhote próprio $x$ alheio) da duração de cada surto de amamentação.

A duração média por episódio de amamentação foi maior na Etapa 1 do que na Etapa 2 (Figura 31). 


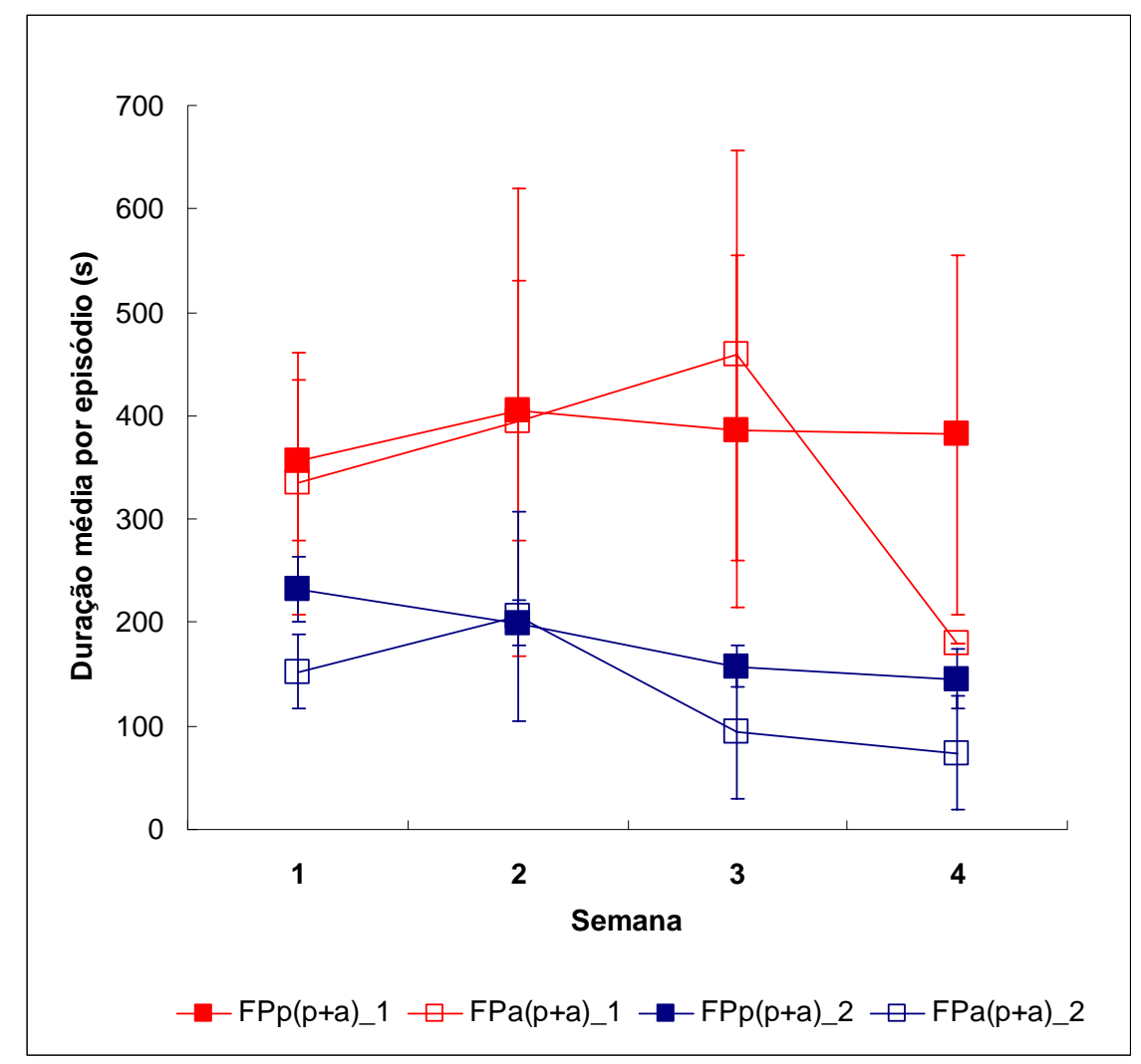

Figura 31: Duração média total de amamentação [FPp $(p+a)]$ e aloamamentação $[\mathrm{FPa}(\mathrm{p}+\mathrm{a})]$ para os filhotes do grupo $\mathrm{FP}(\mathrm{p}+\mathrm{a})$, nas Etapas 1 e 2, ao longo das quatro semanas de observação.

Tabela 11: Análise estatística de duração média por episódio de amamentação $\operatorname{FPp}(p+a)$ e aloamamentação $\mathrm{FPa}(\mathrm{p}+\mathrm{a})$ dos filhotes das Etapas 1 e 2, ao longo das quatro semanas de observação.

\begin{tabular}{lc}
\hline Efeito & $\mathbf{p}$ \\
\hline GRUPO X SEMANA (ausência de interação, paralelismo) & 0,4393 \\
\hline EFEITO DE SEMANA & 0,1447 \\
\hline EFEITO DE GRUPO & 0,0180 \\
FPa(p+a)_1 x FPp $(p+a) \_1$ & 0,8273 \\
FPa $(p+a) \_1 \times F P a(p+a) \_2$ & 0,0134 \\
FPp $(p+a) \_1 \times$ FPp $(p+a) \_2$ & 0,0199 \\
FPa $(p+a) \_2 \times F P p(p+a) \_2$ & 0,0455 \\
\hline
\end{tabular}


$F S \times F P p$

Na Etapa 1 o ganho relativo de peso (peso final - peso inicial / sobre peso inicial) não foi estatisticamente diferente em FS e FPp. Na Etapa 2, contudo, houve maior ganho relativo de peso em FPp do que em FS, um resultado que contradiz a expectativa de que filhotes sozinhos com a mãe deveriam ganhar mais peso relativamente ao seu peso inicial, do que em uma condição em que se encontram misturados e talvez em competição com filhotes de uma ninhada alheia.

Tabela 12: Análise estatística de ganho relativo de peso dos filhotes FS e FPp nas Etapas 1 e 2 .

\begin{tabular}{|c|c|}
\hline Efeito & $p$ \\
\hline FPp_1 x FPp_2 & 0,0051 \\
\hline FPp_1 $1 \times$ FS_- & 0,4883 \\
\hline FPp_2 $\times$ FS_2 & $<0,0001$ \\
\hline$F S 1 \times F S \frac{2}{2}$ & 0,0811 \\
\hline
\end{tabular}

$\mathrm{Na}$ Etapa 2 os pesos dos filhotes foram registrados ao longo das quatro semanas de observação, permitindo uma avaliação mais precisa dos efeitos das condições experimentais do que na Etapa 1. Verificamos, na Etapa 2, tanto na condição FS como na condição FPp, aumentos progressivos de peso com a idade, um resultado previsível. O peso dos filhotes FPp foi maior do que dos filhotes FS na quarta semana, não havendo diferença nas demais semanas (Figura 32). 


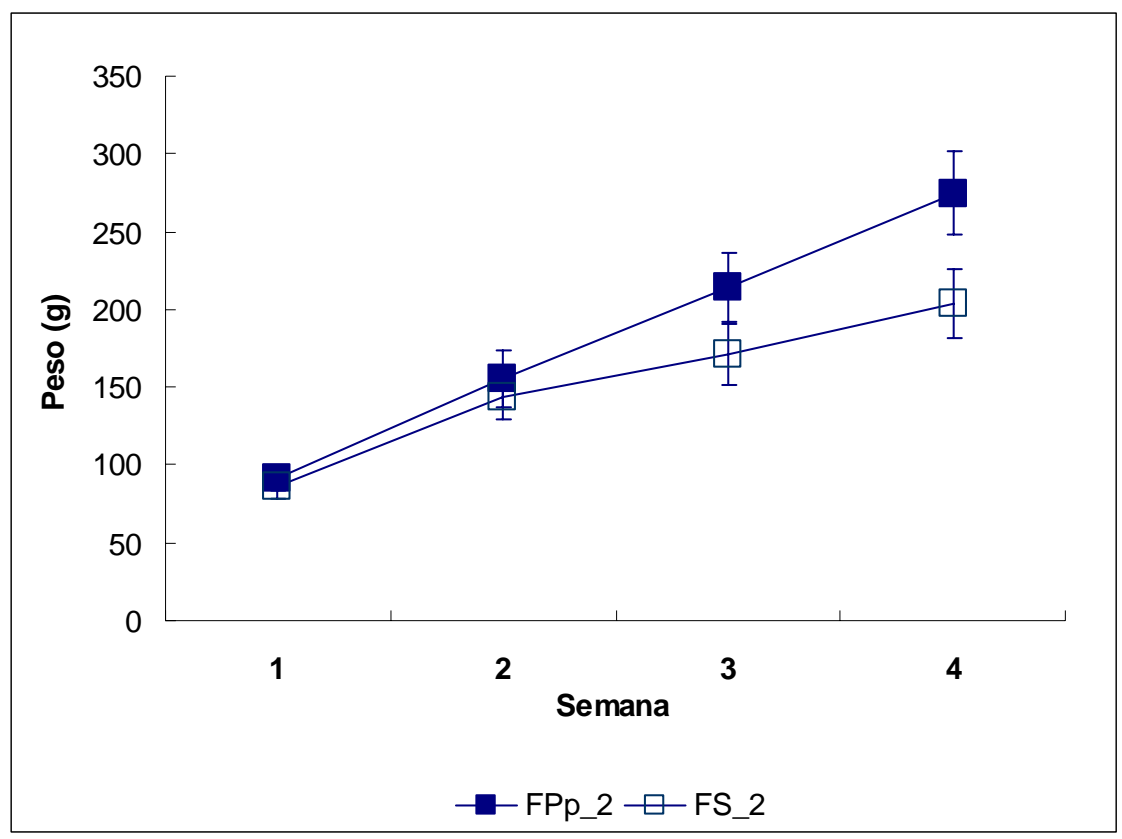

Figura 32: Peso dos filhotes nas condições FS e FPp ao longo das quatro semanas de observação da Etapa 2.

Tabela 13: Análise estatística de peso da Etapa 2 dos filhotes FPp_2 e FS_2, ao longo das quatro semanas de observação.

\begin{tabular}{lc}
\hline Efeito & $\mathbf{p}$ \\
\hline GRUPO X SEMANA (ausência de interação, paralelismo) & $<0,0001$ \\
\hline EFEITO DE SEMANA - FPp_2 & $<0,0001$ \\
SEMANA 1 x SEMANA 2 & $<0,0001$ \\
SEMANA 2 x SEMANA 3 & $<0,0001$ \\
SEMANA 3 x SEMANA 4 & $<0,0001$ \\
\hline EFEITO DE SEMANA - FS_2 & $<0,0001$ \\
SEMANA 1 x SEMANA 2 & $<0,0001$ \\
SEMANA 2 x SEMANA 3 & $<0,0001$ \\
SEMANA 3 x SEMANA 4 & $<0,0001$ \\
\hline SEMANA 1 - FPp_2 x FS_2 & 0,9635 \\
SEMANA 2 - FPp_2 x FS_2 & 0,7469 \\
SEMANA 3 - FPp_2 x FS_2 & 0,0676 \\
SEMANA 4 - FPp_2 x FS_2 & 0,0013 \\
\hline
\end{tabular}


$F P p \times F P(p+a)$

Na Etapa 1, mas não na Etapa 2, os filhotes $\mathrm{FP}(\mathrm{p}+\mathrm{a})$ ganharam mais peso do que os filhotes FPp.

Tabela 14: Análise estatística de ganho relativo de peso dos filhotes FPp e FP(p+a) nas Etapas 1 e 2.

\begin{tabular}{lc}
\hline \multicolumn{1}{c}{ Efeito } & $P$ \\
\hline$F P(p+a)$ 1 $x$ FP(p+a)_2 & 0,6215 \\
FP(p+a)_1 x FPp_1 & 0,0271 \\
FP(p+a)_2 x FPp_2 & 0,6379 \\
FPp_1 1 FPp_2 & 0,1092 \\
\hline
\end{tabular}

Os registros de peso efetuados na Etapa 2, ao longo das semanas, mostram também ter havido um aumento progressivo, tanto em FPp quanto em FP( $p+a)$. Não houve diferenças de peso entre FPp e FP(p+a) em nenhuma das semanas do desenvolvimento, o que significa que o acesso alimentar a uma fêmea lactante, além da mãe, não proporciona ganhos de peso em cobaias (Figura 33).

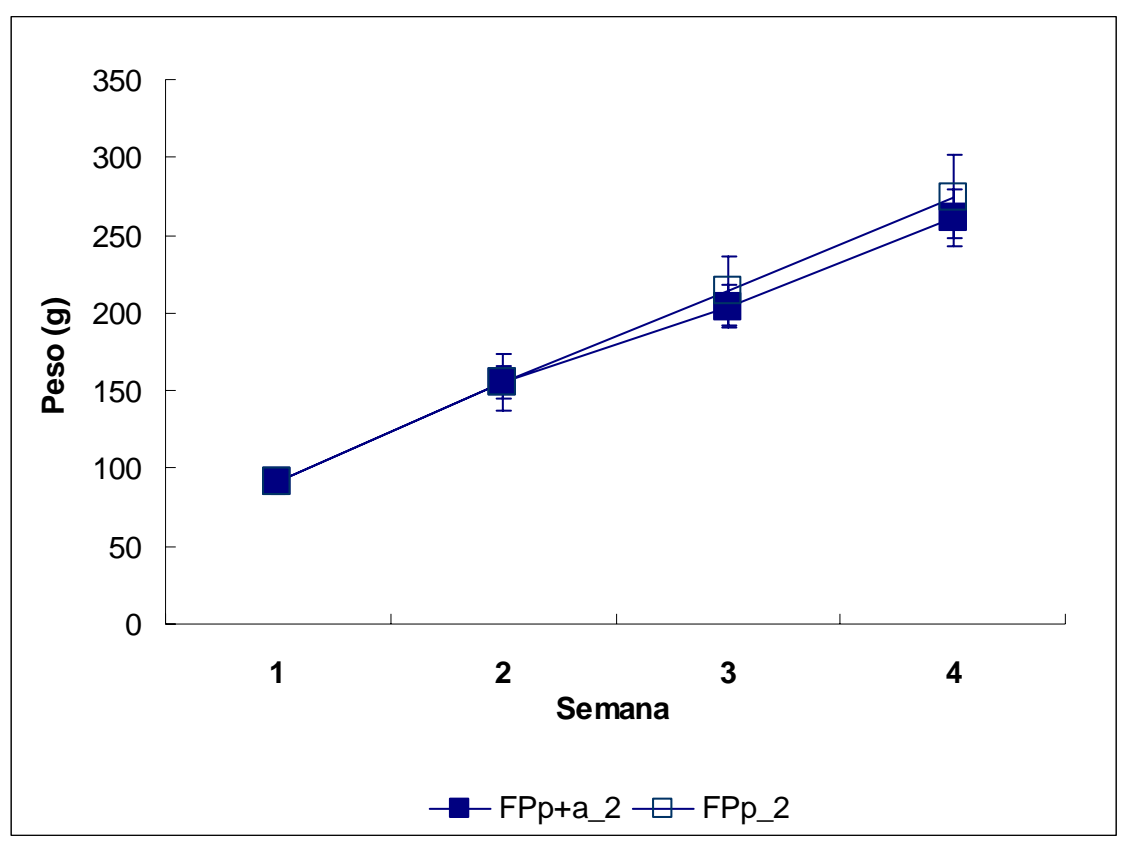

Figura 33: Ganho de peso dos filhotes FP(p+a) e FPp ao longo das quatro semanas de observação da Etapa 2. 
Tabela 15: Análise estatística de peso na Etapa 2 dos filhotes FP(p+a) e FSp nas quatro semanas de observação.

\begin{tabular}{lc}
\hline Efeito & $\mathbf{p}$ \\
\hline GRUPO X SEMANA (ausência de interação, paralelismo) & 0,3127 \\
\hline EFEITO DE SEMANA & $<0,0001$ \\
SEMANA 1 X SEMANA 2 & $<0,0001$ \\
SEMANA 2 X SEMANA 3 & $<0,0001$ \\
SEMANA 3 X SEMANA 4 & $<0,0001$ \\
\hline EFEITO DE GRUPO & 0,8626 \\
\hline
\end{tabular}

\section{Peso das fêmeas na primeira semana da Etapa 2}

A fim de saber se o investimento das fêmeas em aloamamentação teve repercussão sobre o seu peso individual, comparamos, na Etapa $2^{1}$, o peso das fêmeas na condição FS (fêmeas sozinhas) com as da condição FP (fêmeas pareadas: tomando, neste caso as fêmeas que tinham aloamamentado), na primeira semana de vida dos filhotes, que é a semana em que há maior pressão da aloamamentação. O peso médio das fêmeas em FS (média de 3 registros) foi 706,0 g; o peso médio das fêmeas em FP (média de 3 registros) 736,2 g. A diferença FS x FP não foi significativa (Student, $t=1,319, g l=26, p>0,05$ ).

\footnotetext{
${ }^{1}$ Não tínhamos registros de peso das fêmeas na Etapa 1.
} 


\section{DISCUSSÃO}

\section{CARACTERÍSTICAS DA ALOAMAMENTAÇÃO}

A aloamamentação como característica típica do comportamento de cobaias

Nossos resultados mostram que a aloamamentação em cobaias C. porcellus é um fenômeno que se manifesta regularmente quando fêmeas dão à luz simultaneamente ou com poucos dias de diferença, em situação de laboratório. Em nossa amostra de cobaias comuns foram aproximadamente $54 \%$ dos filhotes que alomamaram; e dentre as cobaias albinas, na Etapa 2, aproximadamente 64 \% dos filhotes alomamaram. Esta freqüência sugere ser a aloamamentação uma prática comum na espécie e não pode ser tomada como um artefato de condições especiais de manutenção que coloca em questão o papel funcional que ela desempenha.

Nossos resultados confirmam as observações de Kunkel e Kunkel (1964) de que em grupos que incluíam fêmeas recém paridas, algumas fêmeas amamentavam filhotes alheios (em Fullerton et al., 1974). Künkel e Künkel (1964) afirmam que no contexto de múltiplas lactantes as fêmeas parecem não diferenciar entre seus filhotes e os de outras fêmeas, uma afirmação que não nos parece comprovada e que talvez esteja incorreta.

Confirmamos em vários aspectos e de forma mais sistemática, as observações de Fullerton et al. (1974) que observaram dez pares de fêmeas e suas ninhadas (com uma diferença de até sete dias entre o nascimento das ninhadas) durante nove dias após serem colocadas no mesmo ambiente, registrando as 
amamentações, o contato físico e a proximidade. Notaram que os filhotes mamaram mais de suas mães do que da outra fêmea lactante (foram registrados 729 episódios de amamentação e 172 de aloamamentação durante o período de observação) e que eles ficaram mais freqüentemente em contato físico e próximos de suas mães do que da outra fêmea, uma indicação da existência de um laço de apego recíproco: as mães seriam capazes de reconhecer os seus filhotes de longe e de se aproximar preferencialmente deles, e os filhotes "tenderiam a permanecer próximos à mãe e a mamar mais vezes dela do que de outra fêmea lactante, apesar da emissão indiscriminada de aproximações iniciais à outra fêmea" (p. 153-154). Que tenham sido indiscriminadas as aproximações iniciais representa uma observação importante, do ponto de vista dos resultados que obtivemos: retomaremos a questão mais adiante.

Fullerton et al. (1974) não encontraram indícios de uma fêmea interferir na amamentação de seu filhote por outra fêmea, nem de reagir discriminadamente ao filhote alheio quando este se aproximava para mamar - "Tanto os filhotes quanto as mães parecem tolerar interações de amamentação fora da amamentação da mãe ao filhote próprio", p. 154. Não encontraram mudanças nas categorias comportamentais, ao longo dos nove dias de observação, mas um decréscimo da aloamamentação a partir do terceiro dia. Notam que "embora as interações entre a mãe e os seus próprios filhotes sejam as mais freqüentes, interações sociais em todas as categorias ocorreram também entre as fêmeas e os filhotes das outras ninhadas" e concluem, a partir disso, que o laço de apego mãe-filhote "não é rigidamente exclusivo, mas pode ser categorizado como frouxo (loose attachment)" (p. 152). Embora concordando com Fullerton et al. (1974) a respeito da natureza menos rígida do apego em cobaias, não diríamos que seja frouxo, mas que tem características que o colocam numa categoria apropriada a um sistema reprodutivo com alto investimento gestacional e uma correspondente diminuição dos cuidados aos filhotes precoces. Nossos dados mostram que as interações entre mães e filhotes alheios não são necessariamente da natureza do apego, mas que têm a ver com uma forma de aproveitamento, por filhotes, dos recursos alimentares disponíveis. 
O processo comportamental no qual se insere a amamentação (da mãe e da outra fêmea) parece ser o da manutenção de proximidade entre mãe e filhote. Os filhotes permanecem mais tempo e seguem de maneira mais sistemática a própria mãe, uma característica que provavelmente propicia contato alimentar privilegiado.

Dois aspectos merecem, contudo, ser levantados. Em primeiro lugar, na Etapa 1, notou-se (Figura 22) que, na primeira semana de observação, a distância do filhote às duas fêmeas (a mãe e a outra fêmea) era praticamente a mesma, passando a existir diferença de proximidade somente a partir da segunda semana. Embora este efeito não tenha sido replicado na Etapa 2, ele parece indicar uma indiscriminação, pelo menos do ponto de vista espacial, no início do desenvolvimento (ver Fullerton et al., 1974). Esta indiscriminação não se estende à duração ou freqüência da amamentação, que são fortemente direcionadas à mãe própria, já na semana 1.

O segundo aspecto que merece destaque é a maior distância mãe-filhotes na condição FPp do que na condição FS, um resultado que aparece em ambas as etapas e se estende por todo o período de observação (Figura 21). Possivelmente, o contexto de fêmeas pareadas - com o aumento de indivíduos e de interações disponíveis - interfere na proximidade que o filhote mantém com a sua mãe e gera oportunidades de afastamento. O quanto estas condições iniciais de interação e de apego à mãe se refletem no comportamento adulto dos filhotes é um ponto que merece investigação.

\section{Mudanças ontogenéticas na amamentação}

O desenvolvimento da amamentação, avaliado a partir dos episódios em que filhotes foram vistos buscando a mama da mãe ou da outra fêmea ${ }^{2}$ segue o padrão esperado de decréscimo, já descrito em muitas espécies de mamíferos e já relatado para as cobaias por Stern e Hoffman (1970) e Fullerton et al. (1974) entre outros

\footnotetext{
${ }^{2}$ Não em relação à quantidade de leite ingerida, uma variável que não tínhamos condição de medir.
} 
(Figuras 23, 26 e 29). É importante lembrar que os dados representados nas figuras não incluem, em cada semana, escores nulos que seriam os dos indivíduos que não mamaram nestas semanas. Referem-se aos indivíduos que mamaram pelo menos uma vez. O ângulo de decréscimo destas curvas seria mais abrupto, caso levassem em conta os indivíduos que não mamaram em cada semana.

Do ponto de vista da freqüência de amamentações, verificou-se que as mudanças ontogenéticas foram semelhantes nos filhotes nas condições FS e FPp (Figura 23) - filhotes que mamaram o tempo todo de sua própria mãe - e nos filhotes $F P(p+a)$ - que mamaram e alomamaram (Figura 26): o decréscimo de freqüência ocorreu basicamente depois da segunda semana ${ }^{3}$.

Quanto à duração média de amamentação, verificou-se ser o padrão das curvas (estável entre a semana 1 e 2, com decréscimo posterior - Figuras 24 e 27), semelhante ao padrão das curvas de freqüência, para as condições FS, FPp e $\mathrm{FP}(\mathrm{p}+\mathrm{a})$. Na Etapa 1, as curvas para estas 3 condições coincidem praticamente; na Etapa 2 (Figura 24), nota-se uma diferença inesperada entre FS e FPp, na duração média de amamentação: os filhotes que estavam sozinhos com sua mãe gastaram mais tempo mamando do que os imersos na agitação da situação de pareamento. Não fica clara a razão desta diferença: ela talvez indique que, por um motivo não averiguado, existia uma motivação alimentar maior na amostra de filhotes em FS_2.

A duração média dos episódios de amamentação se manteve, em quase todos os casos, constante ao longo das 4 semanas de observação. É um dado interessante, que indica que, ao longo de seu crescimento, para modular o acesso ao leite, as cobaias recorrem mais à estratégia de aumentar ou diminuir a freqüência de procura das mamas (que acarreta tempos totais de amamentação diferentes) do que à estratégia de aumentar ou diminuir a duração de cada episódio de amamentação (Figuras 25, 28 e 31).

A duração média dos episódios está controlada, contudo, por outras variáveis: foi maior em FS do que em FPp, na Etapa 2, representando talvez mais um sinal de maior motivação.

\footnotetext{
${ }^{3}$ A freqüência de amamentações foi consistentemente maior nos filhotes da Etapa 2.
} 
Que a condição $F P(p+a)$ não levou a maiores freqüências ou durações de amamentação em relação às condições FS ou FPp sugere que alomamar não representa necessariamente, para as cobaias domésticas, a aquisição de um superávit alimentar. O investimento do filhote em mamar de outra fêmea pode redundar em perdas de mamadas na própria mãe, e, no final das contas, os ganhos provenientes de alomamar equilibram-se com as perdas do mamar.

Uma janela temporal para a aloamamentação

O registro do número de filhotes que mamam e alomamam (pelo menos uma vez), ao longo das semanas (Figuras 18 e 19), fornece dados esclarecedores sobre a vigência da aloamamentação. Embora ela possa acontecer eventualmente com um ou outro filhote, até a semana 4, ela se concentra principalmente no início do desenvolvimento: é na semana 1 que o número de filhotes que alomamam se iguala praticamente ao de filhotes que mamam. O desenvolvimento da aloamamentação não segue paralelo ao da amamentação: se fosse, poderíamos levantar a hipótese de que os filhotes dividem seu tempo e seu investimento em busca de leite de uma forma constante entre as fontes disponíveis. O número de indivíduos que alomamam diminui drasticamente a partir da primeira semana, sendo mínimo na última. É possível que esteja em jogo um processo através do qual o filhote passa a discriminar mais entre as fêmeas lactantes cada vez mais a partir da segunda semana, reservando seu esforço de mamada mais e mais à própria mãe.

\section{O desenvolvimento ontogenético da aloamamentação}

Como é que se desenvolve ontogeneticamente, a aloamamentação? Os dados obtidos com os filhotes $\mathrm{FP}(\mathrm{p}+\mathrm{a})$ que tanto mamaram como alomamaram, são inequívocos: nas semanas 1, 2 e 3, que são as semanas em que a motivação alimentar se encontra mais alta, esses filhotes procuraram mais vezes e por mais tempo a mãe $[F P p(p+a)]$ do que a outra fêmea $[F P p(p+a)]$ - Figuras 29, 30 e 31. A aloamamentação - restrita, em termos do número de filhotes que a praticaram, ao início da ontogênese - manteve-se sempre inferior à amamentação e constante ao longo das semanas, sem o decréscimo que é típico do consumo efetuado com a 
mãe. A aloamamentação surgiu, do exame de nossos dados, como uma atividade de importância menor, em termos de investimento e de ganho ingestivo.

O controle da ocorrência e da duração das amamentações pela fêmea

Um mecanismo de defesa do próprio leite poderia ser, nas cobaias, como em muitas outras espécies, o controle seletivo da ocorrência e da duração dos episódios de amamentação. Uma fêmea que distinguisse o filhote próprio do alheio (capacidade que as mães cobaias têm) ganharia em afastar-se deste, impedindo-o de mamar, deixando o caminho livre para o filhote próprio. A defesa do leite também poderia ser efetuada a posteriori, isto é, depois de um filhote ter agarrado a mama a fêmea poderia interromper a mamada através de atos agonísticos.

Não parece plausível pensar que as fêmeas interromperam seletivamente as mamadas alheias: a duração média por episódio de amamentação foi a mesma na amamentação de um filhote alheio $[\mathrm{FPa}(\mathrm{p}+\mathrm{a})]$ ou próprio $[\mathrm{FPp}(\mathrm{p}+\mathrm{a})]$. Se houvesse esse controle a posteriori as durações médias deveriam ser menores no caso do filhote alheio.

Dados de observação direta também sugerem que não esteja sendo usada a interrupção seletiva de mamadas. Para que a interrupção fosse de fato seletiva, seria necessário que a fêmea tivesse contato sensorial com o filhote para reconhecê-lo sempre que este se aproximasse para mamar. Isso muitas vezes não ocorreu: o filhote entrava por baixo da fêmea e chegava à mama antes que pudesse sequer ser brevemente examinado.

As fêmeas cobaias podiam, de outro lado, por flexão do corpo, atingir um filhote que estivesse mamando e afastá-lo, através de um golpe de focinho; ou usar a pata para este fim. Vimos este recurso ser usado indiscriminadamente contra filhotes alheios e próprios, cada vez mais freqüentemente com a aproximação da época de desmame. A interrupção a posteriori representa, assim, uma maneira de a fêmea interromper o contato de amamentação para resguardo próprio.

Foram observados atos de agressão de fêmeas a filhotes fora do contexto de amamentação, quando o filhote simplesmente passava por perto. Não fizemos, por enquanto, o levantamento quantitativo da freqüência destas agressões dirigidas a filhotes alheios ou próprios (temos a possibilidade e a intenção de efetuar esta 
verificação, nas fitas gravadas da Etapa 2). Se constatarmos maior comportamento agonístico em relação a filhotes alheios, teremos uma chave para entender a defesa do leite em cobaias domésticas. Uma vez que não possuem controle sobre a ocorrência imediata ou a duração da amamentação, as fêmeas usariam de agressão diferencial para afastar de si os filhotes alheios. A queda drástica no número de filhotes que alomamaram, depois da primeira semana de vida, dever-se-ia, assim, à aprendizagem de esquiva dos filhotes submetidos a uma agressão aleatória.

\section{O ganho de peso dos filhotes}

Foram pouco sistemáticos e claros os resultados a respeito do ganho de peso dos filhotes: talvez nisso entre a falta, no nosso delineamento experimental, de registros mais completos, incluindo o consumo de alimento sólido além do registro de episódios de amamentação. Os efeitos encontrados na Etapa 1 não se replicaram na Etapa 2. Na Etapa 1, não houve diferenças de ganho de peso entre as condições FS e FPp; na Etapa 2, os filhotes em FPp tiveram um aumento relativo de peso maior do que os filhotes em FS. Na Etapa 1, os filhotes FP(p+a) ganharam mais peso (relativamente ao peso inicial) do que os filhotes FPp, uma indicação de que talvez a aloamamentação representasse vantagem de aptidão. Esta diferença não foi verificada na Etapa 2. Da análise global e dos dados sobre aumento de peso na Etapa 2, obtidos com pesagens em todas as semanas, preferimos ficar com a interpretação de que a aloamamentação não leva a aumentos ponderais.

\section{Peso das fêmeas FS x FP}

Se a aloamamentação representasse um prejuízio forte, para as fêmeas que aloamamentassem, esperar-se-ia que tivessem um peso menor do que as fêmeas mantidas sozinhas. A comparação, feita na Etapa 2, mostra que este não é o caso, não havendo diferença significativa do peso médio na primeira semana de vida dos filhotes (semana em que o maior número de filhotes alomamaram) entre as fêmeas da condição FS e as fêmeas da condição FP que tinham aloamamentado. Este dado é um argumento a mais favorecendo a idéia de que entre cobaias, a aloamamentação não representa um fator de impacto marcado, seja sobre os filhotes, seja sobre as suas mães. 
Embora em seus aspectos gerais, as amostras usadas na Etapa 1 (cobaias comuns) e na Etapa 2 (cobaias albinas) tenham evidenciado comportamentos semelhantes de amamentação e aloamamentação, distinguem-se por uma série de aspectos que a análise estatística desvenda.

Cobaias albinas apresentaram maiores índices de freqüência de amamentação e maiores ninhadas. Na literatura a maioria dos autores não especifica se observaram cobaias albinas ou coloridas, sendo que apenas alguns o fizeram: King (1956) usou cobaias coloridas e albinas, Porter et al. (1973a e 1973b) e Fullerton et al. (1974) usaram animais originados do cruzamento inicial de fêmeas albinas com machos coloridos. Em nosso experimento, as cobaias coloridas eram criadas em condições ambientais naturais (luminosidade, ciclo claro-escuro e temperatura) especificamente com o propósito de servir de alimento para outros animais do zoológico. Já as cobaias albinas eram criadas em condição de biotério, em ambiente fechado, sem controle de ciclo claro-escuro, mas mais protegidas contra o frio e o calor, para serem comercializadas como sujeitos de pesquisa. Não acreditamos que as diferenças encontradas em nosso experimento sejam devido às linhagens coloridas ou albinas, apesar de que não há estudos comprovando que não existam realmente diferenças. O único estudo de nosso conhecimento que investigou diferenças entre cobaias albinas e coloridas é o de Bui \& Vingrys (1999). Os autores pesquisaram o desenvolvimento de receptores visuais em consideração ao papel que a melanogênese possa ter neste processo.

\section{FUNÇÕES POSSÍVEIS DA ALOAMAMENTAÇÃO EM COBAIAS}

A vida coletiva das cobaias fornece um ambiente favorável para a ocorrência do alocuidado e da aloamamentação, pois várias fêmeas podem engravidar e ter partos simultâneos ou próximos um do outro. Não temos informação sobre a sincronicidade natural dos partos em $C$. porcellus, e sobre possíveis efeitos de arrastamento (entrainment) de estro ou de parto, não sendo possível estimar a probabilidade de ninhadas conjuntas em condições normais. Künkele \& Hoeck 
(1995) observaram, contudo, sincronicidade de partos em seis grupos de galea (Galea musteloides); 73\% dos filhotes presentes em cada grupo durante o período de lactação eram filhotes alheios, e em média as fêmeas amamentaram 86\% desses filhotes em seu respectivo grupo. Assim, 98\% de todos os filhotes eram amamentados pela própria mãe e por uma mãe alheia, uma proporção que certamente ultrapassa a que encontramos em C. porcellus.

Mas a oportunidade não leva necessariamente à ocorrência de um comportamento e não gera a sua função. A aloamamentação, que se coloca como uma questão complexa e com vários determinantes de acordo com as exigências ecológicas e a organização social das espécies, não tem a sua natureza facilmente desvendada no caso das cobaias. Uma restrição no processo de produção de leite (Laurien-Kehnen \& Trillmich, 2003), que é específica das cobaias, torna ainda mais instigante a constatação de que esses animais ocasionalmente amamentam filhotes alheios. Como anteriormente mencionado, Laurien-Kehnen e Trillmich (2003), em um experimento em que privavam filhotes de cobaia de alimento sólido - estes filhotes são aptos a consumir desde o nascimento - verificaram que as mães dos filhotes privados não aumentavam a sua produção de leite de modo a compensar a carência experimentalmente produzida. Sua conclusão foi de que as fêmeas lactantes não são sensíveis ao aumento da demanda nutricional dos filhotes, preferindo alocar energia à sua própria manutenção corporal do que à dos filhotes. Isso indica que o leite, cuja produção é rigidamente pré-programada, constitui para as mães cobaias (e para os filhotes) um recurso limitado e limitante que não se esperaria fosse desperdiçado. Esta estratégia de produção "contada" do leite representa uma fonte de pressão para a seleção de estratégias que o mantenham dirigido para a prole (reconhecimento dos próprios filhotes, afastamento dos filhotes alheios, etc). Mesmo representando uma ocorrência periférica na vida das cobaias, a aloamamentação coloca problemas funcionais instigantes.

Em um artigo recente de revisão, Roulin (2002) propôs uma classificação das explicações funcionais para a aloamamentação. À pergunta "por que fêmeas lactantes amamentam filhotes alheios?", Roulin propõe cinco respostas, que poderiam servir de ponto de partida para a discussão de nossos dados. É importante frisar que Roulin não afirma que estas hipóteses tenham a ver com alternativas mutuamente exclusivas. Como em outras questões funcionais, pode haver 
multideterminação de um certo traço comportamental, isto é, ação conjunta de vários fatores adaptativos.

1. Cuidado parental mal direcionado (misdirected): De acordo com esta hipótese, uma mãe transfere leite para um filhote alheio inadvertidamente, direcionando erradamente o seu cuidado materno. Ou ela não se dá conta de que o filhote que mama não é dela, ou este filhote consegue, de uma maneira ou de outra, roubar o seu leite. Esta estratégia seria, segundo Roulin, particularmente eficaz num grupo denso de integrantes, em que a vantagem de ficarem juntos ultrapassa a desvantagem da aloamamentação inadvertida, em que os custos para a mãe que eventualmente aloamamente não sejam grandes a ponto de justificar uma seleção de mecanismos de discriminação e rejeição dos filhotes alheios.

2. Reciprocidade: A hipótese sugere que duas fêmeas podem eventualmente alcançar maior sucesso reprodutivo (maior aptidão darwiniana) quando amamentam o filhote uma da outra, do que quando se restringem à alimentação dos filhotes próprios. Esta troca de favores é mais provável de se fixar quando as fêmeas têm diminuição ocasional da produção de leite ou quando há uma necessidade de se afastarem dos filhotes (o caso das capivaras, em que há "creches" com rodízio de mães), na mesma extensão do que quando não dividem o leite.

3. Seleção de parentesco (kin selection): Uma fêmea tem vantagem em amamentar um filhote alheio se partilham genes, através de ascendência comum. Trata-se de um caso de aptidão abrangente, em que cooperar com um consangüíneo permite uma ampliação da transmissão dos próprios genes que compensa o esforço suplementar investido. Esta estratégia tem melhor probabilidade de se implantar em grupos de animais em que o grau de parentesco é alto ou em que haja possibilidade, por parte de cada mãe, de discriminar o grau de parentesco das outras fêmeas. Espécies em que há criação comunitária dos filhotes são muitas vezes compostas de indivíduos aparentados.

4. Evacuação de leite: A aloamamentação seria uma maneira de mães que amamentam filhotes alheios evacuarem o leite excedente que seus próprios 
filhotes não consumiram. De acordo com esta perspectiva, fêmeas que produzem mais leite do que os próprios filhotes possam consumir seriam propensas a aceitar aloamamentação. Dentre as observações que embasam esta hipótese está a verificação de que mães com ninhadas menores têm maior probabilidade de aceitar filhotes alheios do que as que têm ninhadas maiores (Pusey e Packer, 1994).

5. Aprendizado materno: De acordo com esta hipótese, fêmeas amamentariam filhotes alheios para melhorar suas habilidades maternas. Esta hipótese, de acordo com o próprio Roulin (2002), tem pouca evidência empírica a seu favor. Fêmeas de varias espécies de mamíferos - especialmente em primatas - participam do cuidado aos filhotes quando ainda estão no seu grupo natal, e adquirem assim experiência materna, mas isso não envolve aloamamentação. O treino de aloamamentar apenas poderia ser de valor no caso de fêmeas virgens ou primíparas: é difícil demonstrar que o cuidado com a prole genética não seria suficiente para a aquisição de competência.

Em que medida se estas hipóteses aplicam à aloamamentação, tal como se manifesta na cobaia doméstica, em nossa pesquisa? Roulin (2002) menciona haver evidências empíricas, em pesquisas de campo, a favor das hipóteses de cuidado parental mal direcionado, evacuação de leite e seleção de parentesco e ainda poucas indicações conclusivas a respeito das outras hipóteses.

Cuidado parental mal direcionado: Apesar de haver reconhecimento entre mãe-filhotes de cobaias (Niciporciukas et al., 1999; Tokumaru, 2000), os dados de observação qualitativa indicam que filhotes muitas vezes se aproximam e alcançam a mama sem serem inspecionados pela fêmea. Além disso, a fêmea não parece ter condições de ser seletiva, a favor do filhote próprio, ao interromper a amamentação depois de iniciada. A proximidade entre as ninhadas é um fator que facilita esta iniciativa "não autorizada" dos filhotes. Não havendo controle estrito da mãe pelo acesso às mamas e da permanência nas mesmas, a hipótese do cuidado "mal direcionado" parece se aplicar às cobaias, e a razão funcional para a aloamamentação deve ser procurada na iniciativa e nas vantagens que filhotes eventualmente obtenham por visitar mães alheias. 
Reciprocidade: Embora tenhamos encontrado, numa porcentagem razoável de casos (em 13 de 19 pares de cobaias), reciprocidade no fornecimento de leite, não há condições para afirmar que a aloamamentação decorra basicamente de uma "troca de favores" entre mães cobaias. Na maioria dos casos de reciprocidade, não havia simetria e uma das fêmeas poderia sair perdendo na troca. Quando a aloamamentação era unilateral, o prejuízo era mais claro ainda. O caso das fêmeas FP36 e FP37 ilustra o grau ao qual pode chegar a assimetria: FP36 tinha 2 filhotes e amamentou 3 filhotes da outra; F37 tinha 3 filhotes e não amamentou nenhum filhote de FP36.

A reciprocidade parcial pode, contudo, constituir-se em condição favorável para a aloamamentação, no sentido de, em média, diminuir o desperdício de investimento em fêmeas aloamamentadoras.

Seleção de parentesco: Não temos bases para saber se o grau de consangüinidade entre as fêmeas pareadas entrava na sua disponibilidade para alimentar filhotes alheios. Tanto no Zoológico de São Paulo, como no Biotério BemTe-Vi de Itupeva, os grupos de cobaias eram montados sem renovação sistemática e poderia haver um certo grau de consangüinidade. Uma das idéias iniciais da pesquisa - abandonada por causa de dificuldades de infra-estrutura - era estabelecer pares de fêmeas aparentadas (ou, pelo menos, com um grau de familiaridade prévia que atuasse como sinal de parentesco) a serem contrastados com pares não aparentados (ou não familiares), dentro de um delineamento semelhante ao de König (1994). Uma maior taxa de aloamamentação, no primeiro caso, seria um argumento a favor da hipótese de seleção de parentesco. De qualquer maneira, é possível afirmar que a aloamamentação em cobaias não depende estritamente de um período prévio (ao parto e ao aleitamento) prolongado e de uma consangüinidade próxima: a natureza aleatória do pareamento de fêmeas - dentro das amostras disponíveis de animais e o período relativamente curto de contato entre fêmeas antes que se misturassem as ninhadas não impediram o surgimento do fenômeno.

Evacuação de leite: Esta hipótese não é pertinente no caso da cobaia, pois a quantidade de leite produzida pelas mães, na espécie, é regulada de acordo com o número de filhotes em gestação, não aumentando sua produção com o aumento da demanda/estimulação do filhote (Laurien-Kehnen \& Trillmich, 2003). Se verdadeira a 
hipótese de evacuação de leite, esperar-se-ia que houvesse maior número de filhotes alheios aceitos quando a ninhada fosse pequena (maior probabilidade, em princípio, de uma sobra de leite) do que quando grande. Isto não se verifica: a correlação (tomando as etapas 1 e 2 conjuntamente) entre o tamanho da ninhada e o número de filhotes que alomamaram não é significativa (Pearson, $r=-0,2624, p>$ $0,05)$.

Aprendizado materno: Há alguma discordância quanto à capacidade de mães cobaias melhorarem o seu desempenho materno com a experiência. Segundo Albers et al. (1999a), nem o aumento da idade e experiência das mães cobaias em criar filhotes, nem a diferença de idade das mães no começo do experimento, influenciaram significativamente o comportamento materno. Já Künkele (2000c) atribui à experiência um papel significativo na competência materna de cobaias. Nossas observações indicam (como já mencionado) que a iniciativa para a procura das mamas é própria dos filhotes e mostraram ser pequeno o papel das fêmeas na iniciação da amamentação (mães não recuperam os filhotes que se afastam delas, nem atendem de maneira diferencial ao chamado de aflição dos próprios filhotes, e nem aprendem, quando se monta um procedimento experimental apropriado, a discriminar entre chamados de um filhote próprio e de outro filhote): fica assim comprometida a plausibilidade de uma hipótese que supõe que fêmeas cobaias se valeriam de aumentar o número dos filhotes amamentados como exercício de "mothering". Sendo pequeno o investimento em aloamamentação, não vemos como seria de muita valia enquanto treinamento, em comparação com o esforço dedicado aos filhotes geneticamente relacionados.

\section{HIPÓTESES PARA A EXPLICAÇÃO DA ALOAMAMENTAÇÃO EM COBAIAS DOMÉSTICAS}

Ainda não estamos de posse de todas as informações suficientes do porquê e como ocorre a aloamamentação em cobaias domésticas: o fenômeno é bastante complexo e envolve, como pré-requisitos, as características do sistema social das cobaias, em si bastante complexo. Mas os dados obtidos durante a pesquisa 
permitem que delineemos hipóteses capazes de dar conta do que se sabe e de constituir uma base para novas investigações.

As hipóteses que defendemos decorrem da rejeição de um modelo que anteriormente nos pareceu interessante: a hipótese de que a aloamamentação provém de uma competição dos filhotes por um superávit alimentar.

\section{A hipótese da competição por um superávit alimentar}

Muito no início da pesquisa, acreditávamos que a aloamamentação decorresse de maneira direta da natureza intensamente social e pacífica da organização social das cobaias: seria um traço a mais dentro da tolerância social que marca o comportamento das cobaias dentro do grupo. A aloamamentação ocorreria como uma troca espontânea entre as fêmeas, talvez baseada na funcionalidade da aptidão abrangente, de modo análogo ao caso de espécies que usam de uma estratégia comunitária para se reproduzir (Ebensperger et al., 2002, 2006, 2007; Hayes, 2000; Jennions e Macdonald, 1994; Künkele e Hoeck, 1995).

Ebensberger et al. (2002) que listam uma série de roedores histricognatas neotropicais, aventam a possibilidade de serem estes roedores predispostos evolucionariamente a adotar estratégias de criação, amamentação comunitária de filhotes. "O fato de a maioria dos filhotes de histricognatas neotropicais serem precoces", escrevem eles, "pode ter favorecido a evolução de formas comunitárias de amamentação e uso de ninhos; sendo a condição necessária que os benefícios sejam maiores do que o custo de distribuir leite a filhotes alheios para as fêmeas que se localizam em comunidades, desde que a lactação de filhotes precoces (em contraposição com altriciais) envolva menor custo energético" (p. 145).

Logo, contudo, nos demos conta de que a aloamamentação não era generalizada nem sempre simétrica e equitativa, e de que ela dependia essencialmente da iniciativa dos filhotes. A hipótese da aloamamentação como cooperação não se encaixava, além disso, com os resultados das pesquisas que mostravam o quanto é econômico e muito pouco flexível o processo de geração de leite nas fêmeas lactantes. A observação direta da amamentação nos revelou a existência de fontes sutis do comportamento afiliativo, mas também a de uma competição efetuada sem agonismo intenso, mas merecedora de atenção. 
Foi então que, invertendo a perspectiva, tentamos interpretar a aloamamentação a partir do comportamento dos filhotes e a categorizamos como uma competição por um superávit alimentar. Um resultado parcial da Etapa 1, 0 maior ganho de peso dos filhotes $\mathrm{FP}(\mathrm{p}+\mathrm{a})$ em relação aos filhotes $\mathrm{FPp}$, parecia reforçar a hipótese, na medida em que indicava uma vantagem para o filhote que disputava um ganho suplementar de leite alheio. Alguns filhotes, em virtude de características próprias de motivação ou de vigor - por enquanto não especificadas, poderiam ser explicitadas a partir de estudos que focalizassem o comportamento individual dos filhotes em sua persistência na aproximação de mães alheias e de sua aptidão em vencer as defesas da fêmea - teriam mais sucesso por obterem um suplemento alimentar e por crescerem mais rapidamente, entrando precocemente na carreira reprodutiva. De acordo com esta explicação, o leite seria "roubado", a partir do aproveitamento pelo filhote, da maneira pouco defensiva de a amamentação ocorrer (e dos caminhos - inevitáveis do ponto de vista da fêmea até a mama), representando um prejuízo para as fêmeas cuidadoras. Não é difícil imaginar como a apropriação do recurso alheio (como o colocávamos) poderia ter sido fixada através da seleção natural, uma vez que baseada em diferenças individuais herdáveis e tendo por conseqüência o aumento da aptidão reprodutiva.

A hipótese da competição entre filhotes por um suplemento de alimentação tem recebido confirmação empírica (Riedmann, 1982; Packer et al., 1992). De acordo com a hipótese imunológica de Roulin e Heeb (1999), além do benefício propriamente ponderal e de maturação, um filhote - por mamar de mães diferentes obteria elementos imunes mais diversos e se protegeria contra uma maior variedade de elementos patógenos. Há comprovações de que, de fato, filhotes tomam a iniciativa para ter acesso ao leite alheio, mercê da inadvertência (má alocação) da fêmea lactante e mesmo em condições em que a fêmea defende ativamente seu leite. Em leões marinhos (Eumetopias jubatus), por exemplo, a aloamamentação ocorre ocasionalmente e de duas maneiras diferentes, de acordo com o status reprodutivo da fêmea. As fêmeas primíparas, provavelmente por causa de sua inexperiência, aloamamentaram por significativamente mais tempo do que as fêmeas multíparas, em condições em que claramente se dão conta da aproximação dos filhotes alheios. As fêmeas multíparas, em compensação, atacaram fortemente estes filhotes e somente se deixaram abordar para aloamamentação quando 
estavam dormindo ou quando ocupadas com outra atividade, havendo um "roubo" de leite (Maniscalco et al., 2007). Existem também vários relatos a respeito de competição de filhotes por mamas em casos de aloamamentação (por exemplo, com porcos, Ilman et al., 2006).

Os resultados obtidos nas fases ulteriores da pesquisa demonstraram a limitação da hipótese da competição por um superávit alimentar. De um lado, não foi replicado, na Etapa 2, o dado sobre o aumento ponderal relativo dos filhotes que tivessem alomamado durante o seu crescimento, relativamente aos filhotes que se fixaram na mãe como fornecedora exclusiva de leite $[F P(p+a)$ vs. FPp]. Ao contrário, as curvas de crescimento ponderal destes dois grupos de filhotes indicaram uma impressionante coincidência do trajeto ontogenético. Além disso, evidências a respeito do decurso da aloamamentação durante o crescimento mostraram que era uma atividade localizada no tempo (ocorrendo principalmente, em termos do número de filhotes envolvidos, na primeira semana de vida) e executada muito eventualmente pelos filhotes daí por diante. O investimento de esforço do filhote em procurar a mama da mãe alheia não representa necessariamente a obtenção de um superávit: implica também possivelmente num prejuízo, a perda de acesso à mama materna. A hipótese do superávit alimentar depende, para a sua verificação, de o filhote ter sucesso em uma competição com seus irmãos pelas mamas da mãe própria e em uma competição com os filhotes da outra ninhada pelas mamas da mãe própria e/ou da mãe alheia. Um argumento final tem a ver com a possibilidade de os filhotes aproveitarem, como fonte suplementar e como base para compensarem possíveis déficits de acesso ao leite, os alimentos sólidos que lhes eram proporcionados em abundância. A competência ingestiva não tem apenas a ver com a competição em torno das mamas maternas (ou da mãe alheia), tem a ver com a verdura presente durante o crescimento. 


\section{A hipótese da amamentação oportunista}

Na nova formulação a respeito da aloamamentação em cobaias, permanece a idéia de que a iniciativa provém basicamente dos filhotes e de que se valem da "inadvertência" das fêmeas lactantes disponíveis para obter um suprimento de leite. Diante da possibilidade de obter esse leite da própria mãe e de outra fêmea, abre-se aos filhotes a possibilidade de usar as fêmeas de forma concorrente, no sentido que é dado à palavra em estudos de laboratório, em que animais são postos diante de duas fontes (ou esquemas) de obtenção de alimento e em que alternam entre as fontes de acordo com as características de investimento de esforço e de tempo exigidos por cada uma delas. O recurso à fonte alternativa (a mãe alheia) se encontra em aberto, no início do crescimento, dentro de um contexto facilitador: de um lado, está a natureza bastante benevolente das cobaias adultas em relação aos filhotes; de outro, há a promiscuidade espacial que é inevitável, dentro do ambiente cedido aos animais em condições de cativeiro. Os filhotes, muito cedo, entram em contato com ambas as fêmeas, com os irmãos e os outros filhotes e vão aproveitando o recurso do leite de uma forma oportunística. Que vários dentre eles possam alomamar (às vezes de ambas as ninhadas postas em contato) cria, além de tudo, um contexto de distribuição até certo ponto recíproca que diminui, do ponto de vista das fêmeas que amamentam filhotes alheios, o custo total em aptidão.

Um primeiro aspecto que viesa em favor da própria mãe as tentativas de mamada dos filhotes é a formação de um laço de apego (King, 1956). A observação, por pouco que dure, mostra o quanto - apesar do jeito aleatório de disposição dos filhotes de cobaia dentro da caixa de criação - eles se mantêm próximos à mãe e a seguem em suas andanças pelo espaço dado. Existe uma típica coexistência entre um padrão tranqüilo de mistura entre os filhotes, independentemente de sua ninhada, e uma fidelidade subjacente à mãe, que constitui uma espécie de base móvel. Há procura e manutenção de proximidade com a mãe a partir de possíveis imperativos ecológicos de busca de segurança (imagine-se famílias de preás andando dentro do gramado: permanecer perto da mãe ou de outros indivíduos adultos do grupo tem a função primordial de proteção em relação a eventuais predadores) e, evidentemente, de amamentação. 
É relevante notar que um laço forte de apego pode se desenvolver em relação à mãe alheia. Num caso bastante interessante de adoção, observado durante a Etapa 2 de nosso estudo, uma das duas fêmeas postas em contexto de pareamento, tendo entrado em conflito com a outra, acabou adotando-lhe todos os filhotes. Dois aspectos nos pareceram dignos de nota: de um lado, a reação de seguimento das duas ninhadas, feitas uma só, atrás da fêmea escolhida, conforme o que se esperaria se todos os filhotes tivessem criado um laço de apego para com ela. De outro, a agressão com que a outra fêmea reagia à aproximação de filhotes, quaisquer filhotes, uma agressão que a deixou claramente isolada no espaço disponível. É possível que tenha sido a exibição deste comportamento agonístico em relação à aproximação de filhotes que tenha contribuido para o isolamento da fêmea, e para o fato de não ter amamentado sua prole ${ }^{4}$.

Um segundo aspecto que viesa os filhotes em relação a mamar da própria mãe, possivelmente decorra das interações entre fêmeas e filhotes, logo no início do desenvolvimento. A favor da idéia de que a dinâmica das interações precoces influencia o padrão de escolha posterior pela fêmea lactante está o decréscimo acentuado do número de indivíduos que alomamaram, depois da primeira semana (um resultado bastante robusto, obtido nas duas etapas da pesquisa). Um decréscimo destes, ou é espontâneo, programado intrínsecamente no comportamento dos filhotes de cobaias, ou então, o que nos parece mais provável, é fruto da própria interação. Vimos fêmeas agredirem filhotes que passavam por perto, a uma distância que permitia o eventual reconhecimento destes filhotes como próprios ou alheios. Não temos ainda a quantificação (a partir dos registros em videotape) destes episódios agonísticos, mas acreditamos que, caso se demonstre que são seletivamente dirigidos a filhotes alheios, possam constituir uma das razões pela queda do número de aloamamentações a partir da segunda semana. Se as fêmeas nem sempre têm a oportunidade de inspecionar os filhotes que se candidatam a mamar de suas mamas e nem sempre podem interromper mamadas de forma seletiva, elas poderiam defender o destino de seu leite, por assim dizer, preventivamente, gerando uma esquiva aprendida nos filhotes alheios. Um fator

\footnotetext{
${ }^{4}$ Os dados relativos às duas fêmeas, protagonistas do episódio de adoção, não foram incluídos na amostra analisada na pesquisa.
} 
interacional destes e a suposição de que fêmeas podem diferir na sua propensão agonística explicaria o fato de existirem aloamamentações unilaterais e casos em que não aparece sequer o fenômeno.

De acordo com a hipótese da aloamamentação oportunista, são duas as forças que mantêm a aloamamentação dentro de limites estreitos e a tornam um fenômeno mais equilibrador do consumo, numa situação de disponibilidade múltipla de amamentadoras, do que numa oportunidade para o crescimento diferencial de filhotes: a criação de laços sócio-espaciais de apego e a geração de uma esquiva diferencial.

Indícios de que filhotes possam aprender a discriminar entre fêmeas produtoras de leite de acordo com a disponibilidade que têm para com eles foram relatados por Ekvall (1998), na pesquisa já citada com cervos. Nas primeiras cinco semanas de amamentação, a freqüência de tentativas de filhotes de cervos dirigidas às 6 fêmeas mais novas, distribuíram-se equiprovavelmente, mas não na sexta semana, indicando que os filhotes gradualmente aprendiam a discriminar entre as fêmeas amigáveis e as mais agressivas. No caso dos cervos (Ekvall, 1998), como dos búfalos (Murphey et al., 1991, 1995), o filhote próprio era o primeiro a ter acesso às mamas da mãe, só depois é que os filhotes alheios se aproximavam para alomamar. Não tivemos indicação de que estivesse prevalecendo entre as cobaias a regra de primeiro mamar o filhote próprio, o que reforça ainda mais a conclusão de que fêmeas cobaias não têm controle sobre o acesso de filhotes às suas mamas.

Cobaias não são a única espécie em que a aloamamentação não parece influenciar o desenvolvimento individual de filhotes (dentro da linha de expectativa da hipótese do superávit). São vários os casos documentados de uma aloamamentação sem conseqüências, ou até com conseqüências negativas, na maturação dos alomamadores. Murphey et al. (1995), trabalhando com búfalos, verificaram que uma aloamamentação freqüente era associada a uma diminuição da taxa de crescimento dos bezerros; em cervos vermelhos, bezerros que alomamavam cresciam menos do que os outros (Bartos et al., 2001). Em porcos, Olsen et al. (1998) demonstraram não haver diferença entre os filhotes que alomamaram ou não; Illmann et al. (2006), observaram em porcos, tanto nos que chamaram de "ganhadores" como nos "perdedores de tetas", uma ausência de ganho ponderal decorrente da aloamamentação. 
A aloamamentação pode até ser vista, dependendo do caso, como um recurso usado por filhotes para compensar pela baixa qualidade ou quantidade do leite conseguido com a mãe (Bartos et al., 2001). Illman et al. (2006), contudo, no trabalho com porcos, eliminaram (como nós também pudemos eliminar, no caso das cobaias), a hipótese de uma aloamamentação compensatória: os porcos que alomamaram tinham peso equivalente ao dos outros, no começo das observações, não tendo, portanto, carência que explicasse terem alomamado posteriormente.

Não há como, no presente momento, negar em absoluto que a aloamamentação tenha efeitos benéficos para os alomamadores. Efeitos desses poderiam se manifestar em dimensões que não fossem ponderais (na área imunológica, por exemplo) e poderiam se manifestar, bem mais tarde, por uma maior aptidão reprodutiva dos alomamadores, constatada através de comparações a longo prazo das ninhadas que eles e os outros produzem. Tudo indica, contudo, até prova em contrário, que a aloamamentação surja apenas como um subproduto das características que marcam a vida social da cobaia doméstica, sem benefícios individuais seletivos. O sistema de reprodução por haréns, a restrição espacial, a diminuição de agressividade decorrente do processo de domesticação, o modo especial de os caviídeos amamentarem a prole (sem controle estrito sobre quem é que está sendo amamentado, em dado momento), todos esses são fatores que, aliados a uma tendência de os filhotes "experimentarem" as fontes de leite disponíveis, propiciam o surgimento da aloamamentação. A defesa da destinação do leite pelas fêmeas cobaias através de comportamentos agonísticos seletivos, dirigidos a filhotes alheios, uma possibilidade aqui colocada com cautela, seria, se comprovada, mais um peça para compor o quebra-cabeça e um progresso em direção a um modelo causal e funcional a respeito de um comportamento de cuidado bastante intrigante. 
AlBeRS, P. C. H.; TIMMERMANS, P. J. A. \& VOSSEN, J. M. H. Evidence for the existence of mothering styles in guinea pigs (Cavia aperea $f$. porcellus). Behaviour, 136, 469 - 479, 1999a.

ALBERS, P. C. H.; TIMMERMANS, P. J. A. \& VOSSEN, J. M. H. Maternal behaviour in the guinea pig (Cavia aperea $f$. pocellus): a comparison of multiparous, and primiparous, and hand reared primiparous mothers. Netherlands Journal of Zoology, 49(4), 275 - 287, 1999b.

ALTMANN, J.; ALTMANN, S. A. \& HAUSFATER, G. Primate infant's effects on mother's future reproduction. Science, 201, 1028 - 1030, 1978.

ANDRIOLO, A.; PARANHOS DA COSTA, M. J. R. \& SCHMIDEK, W. Suckling behaviour in water buffalo (Bubalus bubalis): development and individual differences. Revista de Etologia, 3(2), 1 - 8, 2001.

ASDELL, S. A. Patterns of mammalian reproduction. Cornell University Press, New Cork, 1964.

AVERY, G. T. Notes on reproduction in guinea pigs J. Comp. Psicol.., 5, 373-396, 1925.

BARTOS, L.; VANKOVÁ, D.; HYÁNEK, J. \& SILER, J. Impact of allosucking on growth of farmed red deer calves (Cervus elaphus). Animal Science, 72, $493-$ $500,2001$.

BEISIEGEL, B. de M. Comportamento paterno e dinâmica familiar na cobaia doméstica. Dissertação de Mestrado. Departamento de Psicologia Experimental. Instituto de Psicologia, USP, 1993.

BIRGERSSON, B.; EKVALL, K; TEMRIN, H. Allosuckling in fallow deer, Dama dama. Animal Behavior, 42, 326-327, 1991. 
BOINSKI, S. Birth synchrony in squirrel monkeys (Saimiri oerstedi). Behav. Ecol. Sociobiol., 21, $393-400,1987$.

BONESS, D. J., CRAIG, M. P., HONIGMAN, L. \& AUSTIN, S. Fostering behavior and the effect of female density in Hawaiian monk seals, Monachus schauinslandi. Journal of Mammology, 79,1060-1069, 1998.

BROWN, R. Capítulo 5 - "Hormônios e comportamento parental" em: Comportamento materno em mamíferos, bases teóricas e aplicações aos ruminantes domésticos. Mateus J. R. Paranhos da Costa e Valter U. Comberg. SBEt. 1998.

BUI, B. V. \& VINGRYS, A. J. Development of receptoral responses in pigmented and albino guinea-pigs (Cavia porcellus). Documenta Ophthalmologica, 99, 151 170, 1999.

BUSSAB, V. S. R. Capítulo 3 - "Uma abordagem psicoetológica do comportamento materno" em: Comportamento materno em mamíferos, bases teóricas e aplicações aos ruminantes domésticos. Mateus J. R. Paranhos da Costa e Valter U. Comberg. SBEt. 1998.

CLARK, M. M. \& GALEF, B. G. Jr. Why some male Mongolian gerbils may help at the nest: testosterone, asexuality and alloparenting. Animal Behaviour, 59, 801 $806,2000$.

CLUTTON-BROCK, T. H. The evolution of parental care. Princeton University Press. 1991.

CLUTTON-BROCK, T. H. Breeding together: Kin selection and mutualism in cooperative vertebrates. Science, 296, 69 - 72, 2002.

CLUTTON-BROCK, T. H.; ALBON, S. D. \& GUINNESS, F. E. Parental investment and sex differences in juvenile mortality in birds and mammals. Nature, 300, $178-180,1985$.

DIGGLE, P. J., LIANG, K. AND ZEGER, S. L. Analysis of Longitudinal Data. Oxford Science Publications, New York ,1994. 
EBENSPERGER, L. A.; HURTADO, M. J. \& LEÓN, C. An experimental examination of the consequences of communal versus solitary breeding on maternal condition and the early postnatal growth and survival of degus, Octodon degus, pups. Animal Behaviour, 73, 185 - 194, 2007.

EBENSPERGER, L.A.; HURTADO, M.J. \& VALDIVIA, I. Lactating Females Do Not Discriminate Between Their Own Young and Unrelated Pups in the Communally Breeding Rodent, Octodon degus. Ethology, 112, 921-929, 2006.

EBENSPERGER, L. A.; Veloso, C. \& WALleM, P. K. Do female degus communally nest and nurse their pups? Journal of Ethology, 20, 143 - 146, 2002.

EKVALL, K. Effects of social organization, age and agressive behaviour on allosuckling in wild fallow deer. Animal Behaviour, 56, 695 - 703, 1998.

FEDIGAN, L. M. \& ROSE, L. M. Interbirth interval variation in three sympatric species of neotropical monkey. Am. J. Primatol., 37, 9 - 24, 1995.

FULLERTON, C.; BERRYMAN, J. C. \& PORTER, R. On the nature of mother-infant interactions in the guinea-pig (Cavia porcellus). Behaviour, 48, 145-156, 1974.

GALEF, B. G. J. Information centers of Norway Rats: sites for information exchange and information parasitism. Animal Behavior, 41, 295-301, 1991.

GRINNELL, J. \& McCOMB, K. Maternal grouping as a defense against infanticide by males: evidence from field playback experiments on African lions. Behav. Ecol. 7, 55-59, 1996.

HAYES, L. D. To nest communally or not to nest communally: a review of rodent communal prairie voles, Microtus ochrogaster. Animal Behaviour, 59, 677 $688,2000$.

HAYES, L. D. \& SOLOMON, N. G. Mechanisms of maternal investment by communal prairie voles, Microtus ochrogaster. Aninal Behaviour, 72, 1069 - 1080, 2006.

HAYES, L.D., SOLOMON, N.G. A comparison of the maternal care of females within prairie vole (Microtus ochrogaster) communal groups. Ethology, 113, 543-554, 2007. 
HENNESSY, M. B. Enduring maternal influences in a precocial rodent. Developmental Psychobiology, 42, 225-236, 2003.

HOFFMAN, J. I. \& AMOS, W. Does kin selection influence fostering behaviour in Antartic fur seals (Arctocephalus gazella)? Proc. R. Soc. B, 272, $2017-2022$, 2005.

HOOGLAND, J. L., TAMARIN, R. H. \& LEVY, C. K. Communal nursing in prairie dogs. Behav. Ecol. Sociobiol., 24,91-95, 1989.

ILLMAN, G.; POKORNÁ, Z. \& SPINKA, M. Nursing synchronization and milk ejection failure as maternal strategies to reduce allosuckling in pair-housed sows (Sus scrofa domestica). Ethology, 111, 652 - 668, 2005.

ILLMAN, G.; POKORNÁ, Z. \& SPINKA, M. Allosuckling in domestic pigs: Teat acquisition strategy and consequences. Appl. Anim. Beh. Sc. 13-26, 2006.

JÄCKEL, M., \& TRILLMICH, F. Olfactory Individual Recognition of Mothers by Young Guinea-Pigs (Cavia porcellus). Ethology, 109, 197-208.

JARMAN, P. J. The social organization of antelope in relation to their ecology. Behaviour, 48, 215-267, 1974.

JENNIONS, M. D., MACDONALD, D.W. Cooperative breeding in mammals. Trends Ecol. Evol., 9, 89-93, 1994.

KASPARIAN, K.; GEIBLER, E. \& TRILLMICH, F. Optimal offspring size in a small mammal: an exception to the tradeoff invariant life-history rule. Oikos, 111, $271-278,2005$.

KING, J. A. Social relations of the domestic guinea pig living under semi-natural conditions. Ecology, 37(2), 221 - 228, 1956.

KÖNIG, B. Maternal investment of communally nursing female house mice (Mus musculus domesticus). Behavioural Processes, 30, 61 - 73, 1993.

KÖNIG, B. Fitness effects of communal rearing in house mice: the role of relatedness versus familiarity. Animal Behaviour, 48, 1449 - 1457, 1994.

KÖNIG, B. Cooperative care of young in mammals. Naturwissenschaften, 84, $95-$ 104, 1997. 
KUNKEL, P. \& KUNKEL, I. Beiträge zur ethologie des hausmeerschweinchens Cavia aperea f. porcellus (L.). Z. Tierpsychol., 21, 602 - 641, 1964.

KÜNKELE, J. Effects of litter size on the energetics of reproduction in a highly precocial rodent, the guinea pig. Journal of Mammalogy, 81(3), 691 - 700, 2000a.

KÜNKELE, J. Energetics of gestation relative to lactation in a precocial rodent, the guinea pig (Cavia porcellus). J. Zool. Lond., 250, 533 - 539, 2000b.

KÜNKELE, J. \& HOECK, H. N. Communal suckling in the cavy Galea musteloides. Behav. Ecol. Sociobiol., 37, 385 - 391, 1995.

KÜNKELE, J. \& TRILLMICH, F. Are precocial young cheaper? Lactation energetics in the guinea pig. Physiological Zoology, 70(5), 589 - 596, 1997.

KÜNZL, C. \& SACHSER, N. The behavioral endocrinology of domestication: a comparison between the domestic guinea pig (Cavia aperea $f$. porcellus) and its ancestor, the Cavy (Cavia aperea). Hormones and Behavior, 35, 28 - 37, 1999.

LAURIEN-KEHNEN, C. \& TRILLMICH, F. Lactation performance of guinea pigs (Cavia porcellus) does not respond to experimental manipulation of pup demands. Behav. Ecol. Sociobiol., 53, 145 - 152, 2003.

LECOMTE, N.; KUNTZ, G.; LAMBERT, N.; GENDNER, J. P.; HANDRICH,Y.; MAHO, Y. L. \& BOST, C. A. Alloparental feeding in the king penguin. Animal Behaviour, 71, 457 - 462, 2006.

LEE, P. C. Allomothering among African elephants. Animal Behaviour, 35, 278 - 291, 1987.

LEE, P. C. The meanings of weaning: growth, lactation, and life history. Evolutionary Anthropology, 87 - 96, 1997.

LEWIN, R. Social Life: a question of costs and benefits. Science, 236, 775-777, 1987.

LINGLE, S.; RENDALL, D.; WILSON, W. F.; DEYOUNG, R. W. \& PELLIS, S. M. Altruism and recognition in the antipredator defence of deer: 2 . Why mule deer help nonoffspring fawns. Animal Behaviour, 73, 907 - 916, 2007. 
MACHATSCHKE, I. H.; WALLNER, B.; SCHAMS, D. \& DITTAMI, J. Social environment affects peripheral oxytocin and cortisol during stress responses in guinea-pigs. Ethology. 110, 161-176, 2004.

MAESTRIPIERI, D. Vigilance costs of allogrooming in Macaque mothers. Am. Nat. 141, 744-753, 1993.

MANISCALCO, J.M., HARRIS, K.R., ATKINSON, S., \& PARKER, P. Alloparenting in Steller sea lions ( Eumetopias jubatus ): correlations with misdirected care and other observations Journal of Ethology, 25, 125-131, 2007

MANN, J. \& SMUTS, B. B. Natal attraction: allomaternal care and mother-infant separations in wild bottlenose dolphins. Animal Behaviour, 55, 1097 - 1113, 1998.

McKENNA, J. J. The evolution of allomothering behavior among Colobine Monkeys: function and opportunism in evolution. American Anthropologist, New Series, 81(4), 818 - 840, 1979.

McSHEA, W. J. Social tolerance and proximate mechanisms of dispersal among winter groups of meadow voles, Microtus pennsylvanicus. Animal Behavior, 39, 346-351, 1990.

MILLAR, J. S. Energetics of reproduction in Peromyscus leucopus: the cost of lactation. Ecology, 59(5), 1055 - 1061, 1978.

MIRANDA, J. M. D.; AGUIAR, L. M.; LUDWIG, G; MORO-RIOS, R. F. \& PASSOS, F. C. The first seven months of an infant of Alouatta guariba (Humboldt) (Primates, Atelidae): interactions and the development of behavioral patterns. Revista Brasileira de Zoologia, 22(4), 1191 - 1195, 2005.

MONTICELLI, P. F. \& ADES, C. A case study of allomaternal suckling in a group of captive wild cavies, Cavia aperea. Anais XXVIII International Ethological Conference, Florianópolis-Brasil, pág. 186. Florianópolis - Brazil. August 20 27, 2003.

MOORE, C. L. Maternal behavior, infant development, and the question of developmental resources. Developmental Psychobiology, 49, 45 - 53, 2007. 
MORICEAU, S. \& SULLIVAN, R. M. Neurobiology of infant attachment. Developmental Psychobiology, 47, 230 - 242, 2005.

MURPHEY, R. M.; PARANHOS DA COSTA, M. J. R.; SOUZA LIMA, S. O de \& MOURA DUARTE, F. A. de Communal suckling in water buffalo (Bubalus bubalis). Applied Animal Behaviour Science, 28, 341 - 352, 1991.

MURPHEY, R. M.; PARANHOS DA COSTA, M. J. R. \& SILVA, R. G. E SOUZA, R. C. Allonursing in river buffalo, Bubalus bubalis: nepotism, incompetence or thievery?.Animal Behavior, 49, 1611-1616, 1995.

NICIPORCIUKAS, C; ADES, C \& TOKUMARU, R. S. Guinea pig pups do recognize their mother. Revista de Etologia, 1 (1), 3-8, 1999.

NOGUEIRA, S. S. C.; OTTA, E.; DIAS, C. T. DOS S.; NOGUEIRA-FILHO, L. G. Alloparental behavior in the Capybara (Hydrochoerus hydrochaeris). Revista de Etologia, Vol. 2 (1), 17-21, 2000.

O'BRIEN, T. \& ROBINSON, J. G. Allomaternal care by female wedge-capped capuchin monkeys: effects of age, rank and relatedness. Behaviour, 119(1-2), $30-50,1991$.

OFTEDAL, O. T. Milk composition, milk yield and energy output at peak lactation: a comparative review. Symp. Zool. Soc. Lond., 51, 33 - 85, 1984.

OLSEN, A.N.W., DYBKJAER, L., VESTERGAARD, K.S. Cross-suckling and associated behaviour in piglets and sows. Appl. Anim. Behav. Sci. 61, 13-24, 1998.

PACKER, C.; LEWIS, S. \& PUSEY, A. A comparative analysis of non-offspring nursing. Animal Behaviour, 43, 265-281, 1992.

PARANHOS DA COSTA, M. J. R.; ANDRIOLO, A.; OLIVEIRA, J. F. S. \& SCHIMIDEK, W. R. Suckling and allosuckling in river buffalo calves and its relation with weight gain. Applied Animal Behaviour Science, 66, 1-10, 2000.

PEAKER, M. \& TAYLOR, E. Sex ratio and litter size in the guinea pig. Journal of Reproduction \& Fertility,108, 63 - 67, 1997. 
PERRIGO, G. Breeding and feeding strategies in deer mice and house mice when females are challenged to work for their food. Animal Behavior, 35, 12981316, 1987.

PORTER, R. H.; FULLERTON, C. \& BERRYMAN, J. C. Guinea-pig maternal-young attachment behaviour. Zeitscrhift fur Tierpsychology, 32, 489 - 495, 1973a.

PORTER, R. H.; BERRYMAN, J. C. \& FULLERTON, C. Exploration and attachment behaviour in infant guinea pigs. Behaviour, 45, $312-322,1973 \mathrm{~b}$.

PORTER, B. T. \& TRITES, A. W. Suckling attempts during winter by two non-filial Steller sea lion pups (Eumetopias jubatus). Mammalia, 68(1), 23 - 26, 2004.

PRENTICE, A. M. \& WHITEHEAD, R. G. The energetics of human reproduction. Symp. Zool. Soc. Lond., 75, 275 - 304, 1987.

PRICE, E. O. Behavioral aspects of animal domestication. The Quartely Review of Biology. 59, 1 - 32, 1984.

PUSEY, A. E. \& PACKER, C. Non-offspring nursing in social carnivores: minimizing the costs. Behavioral Ecology, 5, 362-374, 1994.

RIEDMAN, M. L. The evolution of alloparental care and adoption in mammals and birds. The Quaterly Review Biology, 57, 405-435, 1982.

ROOD, J. P. \& WEIR, B. J. Reproduction in female wild guinea-pigs. J. Reprod. Fert., 23, 393-409, 1970.

ROOD, J. P. Ecological and behavioral comparisons of three genera of Argentina cavies._Animal Behavior Monographs, 5, 1972.

ROULIN, A. Why do lactating females nurse alien offspring? A review of hypotheses and empirical evidence. Animal Behaviour, 63, 201-208, 2002.

ROULIN, A. \& HEEB, P. The immunological function of allosuckling. Ecology Letters, 2, $319-324,1999$.

RUSSELL, J. K. Altruism in coati bands: nepotism or reciprocity? In: Social behavior of female vertebrates. Wasser, S. K.; New York: Academic Press. 263 - 290, 1983.

SIKES, R. S. Costs of lactation and optimal litter size in northern grasshopper mice (Onychomys leucogaster). J. Mammal., 76, 348 - 357, 1995. 
STEINHEIM, G; MYSTERUD, A.; HOLAND, O; BAKKEN, M. \& ADNOY, T. The effect of initial weight of the ewe on later reproductive effort in domestic sheep (Ovis aries). J. Zool. Lond., 258, 515 - 520, 2002.

STERN, J.J., \& HOFFMAN, B. Effects of social isolation until adulthood on maternal behavior in guinea pigs. Psychon. Sci., 21, 15-16, 1970.

TAKAMATSU, A. T.; TOKUMARU, R. S. \& ADES, C. Allosuckling in guine pigs (Cavia porcellus). Anais XXVIII International Ethological Conference, pág. 203. Florianópolis - Brazil, august 20 - 27, 2003.

TAKAMATSU, A. T.; TOKUMARU, R. S. \& ADES, C. Obtendo o recurso alheio: a aloamamentação em filhotes de cobaias Cavia porcellus. Anais do III Congresso Brasileiro de Mastozoologia, pág. 95. Aracruz - ES, 12 - 16 de outubro, 2005.

TOKUMARU, R. S. Tranqüilizarão comportamental: efeitos do acompanhante e da familiaridade do ambiente sobre a reação da cobaia juvenil. Dissertação de Mestrado. Departamento de Psicologia Experimental - Instituto de Psicologia. USP, 1995.

TOKUMARU, R. S. Reconhecimento entre mãe e filhote na cobaia (Cavia porcellus). Tese de Doutorado. Departamento de Psicologia Experimental - Instituto de Psicologia. USP, 2000.

VALENCIA, J.; CRUZ, C. DE LA; CARRANZA, J. \& MATEOS, C. Parents increase their parental effort when aided by helpers in a cooperatively breeding bird. Animal Behaviour, 71, 1021 - 1028, 2006.

VAN SCHAIK, C. P. \& VAN NOORDWIJK, M. A. The hidden costs of sociality: intragroup variation in feeding strategies in Sumatran long-tailed macaques (Macaca fascicularis). Behaviour, 99, 296-315, 1986.

VERNON, R. G. \& FLINT, D. J. Adipose tissue: Metabolic adaptation during lactation. Symp. Zool. Soc. Lond., 51, 119-145, 1984.

VÍCHOVÁ, J. \& BARTOS, L. Allosuckling in cattle: gain or compensation? Applied Animal Behaviour Science, 94, 223-235, 2005. 
YOUNG, W. C. Psychobiology of sexual behavior in the guinea pig. Advances in the Study of Behavior, 2, 1-109, 1969.

YOUNG, W. C.; DEMPSEY, E. W. \& MYERS, H. I. Cyclic reproductive behavior in the female guinea pig. J. Comp. Psychol., 19 (2), 313-335, 1935.

WEIR, B. J. Notes on the origin of the domestic guinea-pig. Symp. Zool. Soc. Lond., 34, 437-446, 1974.

WEWERS, D.; KAISER, S. \& SACHSER, N. Maternal separation in Guinea-pigs: A study in behavioural endocrinology. Ethology, 109, 443-453, 2003.

WINER, B.J. Statistical Principles in Experimental Design, 2d edition, New York : McGraw-Hill Book Co, 1971. 
ANEXOS 
Deixamos disponível a base de dados em forma de anexos para que pessoas interessadas possam eventualmente reanalisar ou reinterpretar os resultados da pesquisa.

Anexo I: Médias descritivas dos dados de Freqüência Média de Amamentação dos filhotes FS_1, FPp_1, FS_2 e FPp_2, que mamaram pelo menos uma vez em cada semana.

\begin{tabular}{|c|c|c|c|c|c|c|c|c|}
\hline Variável & Etapa & Condição & Semana & $\mathrm{n}$ & Média & $\begin{array}{l}\text { Erro- } \\
\text { padrão }\end{array}$ & Mínimo & Máximo \\
\hline \multirow{16}{*}{$\begin{array}{l}\text { Freqüência } \\
\text { Média de } \\
\text { Amament. }\end{array}$} & \multirow{8}{*}{1} & \multirow{4}{*}{ FPp } & 1 & 20 & 2,88 & 0,41 & 1,00 & 7,00 \\
\hline & & & 2 & 21 & 3,19 & 0,31 & 1,00 & 6,00 \\
\hline & & & 3 & 20 & 2,65 & 0,35 & 0,50 & 6,00 \\
\hline & & & 4 & 9 & 1,33 & 0,29 & 0,50 & 3,50 \\
\hline & & \multirow{4}{*}{ FS } & 1 & 26 & 2,87 & 0,21 & 1,00 & 4,50 \\
\hline & & & 2 & 26 & 3,19 & 0,25 & 1,00 & 5,50 \\
\hline & & & 3 & 25 & 2,64 & 0,30 & 0,50 & 6,50 \\
\hline & & & 4 & 19 & 1,34 & 0,21 & 0,50 & 3,00 \\
\hline & \multirow{8}{*}{2} & \multirow{4}{*}{ FPp } & 1 & 23 & 4,80 & 0,44 & 1,00 & 8,67 \\
\hline & & & 2 & 23 & 4,12 & 0,36 & 1,67 & 8,33 \\
\hline & & & 3 & 23 & 3,19 & 0,63 & 0,33 & 14,00 \\
\hline & & & 4 & 15 & 3,10 & 0,91 & 0,25 & 11,00 \\
\hline & & \multirow{4}{*}{ FS } & 1 & 30 & 3,87 & 0,35 & 1,00 & 9,00 \\
\hline & & & 2 & 30 & 4,80 & 0,37 & 1,50 & 10,00 \\
\hline & & & 3 & 30 & 3,53 & 0,32 & 1,00 & 8,67 \\
\hline & & & 4 & 30 & 2,94 & 0,30 & 0,33 & 6,67 \\
\hline
\end{tabular}


Anexo II: Médias descritivas dos dados de Duração Média Total de Amamentação dos filhotes FS_1, FPp_1, FS_2 e FPp_2, que mamaram pelo menos uma vez em cada semana.

\begin{tabular}{|c|c|c|c|c|c|c|c|c|}
\hline Variável & Etapa & Condição & Semana & $\mathrm{n}$ & Média & $\begin{array}{l}\text { Erro- } \\
\text { padrão }\end{array}$ & Mínimo & Máximo \\
\hline \multirow{16}{*}{$\begin{array}{l}\text { Duração } \\
\text { Média } \\
\text { Total (s) }\end{array}$} & \multirow{8}{*}{1} & \multirow{4}{*}{ FPp } & 1 & 20 & 835,50 & 125,60 & 120,00 & 2160,00 \\
\hline & & & 2 & 21 & 884,29 & 100,35 & 90,00 & 2280,00 \\
\hline & & & 3 & 20 & 772,50 & 150,34 & 90,00 & 2460,00 \\
\hline & & & 4 & 9 & 493,33 & 122,79 & 150,00 & 1260,00 \\
\hline & & \multirow{4}{*}{ FS } & 1 & 26 & 872,88 & 79,34 & 150,00 & 1710,00 \\
\hline & & & 2 & 26 & 1120,38 & 78,55 & 360,00 & 2190,00 \\
\hline & & & 3 & 25 & 744,00 & 75,14 & 240,00 & 1560,00 \\
\hline & & & 4 & 19 & 350,53 & 51,25 & 60,00 & 810,00 \\
\hline & \multirow{8}{*}{2} & \multirow{4}{*}{ FPp } & 1 & 23 & 993,20 & 91,25 & 184,33 & 2196,67 \\
\hline & & & 2 & 23 & 766,94 & 81,70 & 142,50 & 1621,67 \\
\hline & & & 3 & 23 & 487,52 & 88,78 & 12,33 & 1422,00 \\
\hline & & & 4 & 15 & 371,59 & 116,45 & 11,25 & 1322,00 \\
\hline & & \multirow{4}{*}{ FS } & 1 & 30 & 1370,92 & 106,38 & 299,50 & 2702,00 \\
\hline & & & 2 & 30 & 1364,36 & 92,75 & 467,00 & 2625,00 \\
\hline & & & 3 & 30 & 1286,14 & 99,49 & 438,00 & 2463,33 \\
\hline & & & 4 & 30 & 782,31 & 92,86 & 8,33 & 2002,67 \\
\hline
\end{tabular}

Anexo III: Médias descritivas dos dados de Duração Média por Episódio de Amamentação dos FS_1, FPp_1, FS_2 e FPp_2, que mamaram pelo menos uma vez em cada semana.

\begin{tabular}{|c|c|c|c|c|c|c|c|c|}
\hline Variável & Etapa & Condição & Semana & $\mathrm{n}$ & Média & $\begin{array}{l}\text { Erro- } \\
\text { padrão }\end{array}$ & Mínimo & Máximo \\
\hline \multirow{16}{*}{$\begin{array}{l}\text { Duração } \\
\text { Média/ } \\
\text { episódio } \\
\text { (s) }\end{array}$} & \multirow{8}{*}{1} & \multirow{4}{*}{ FPp } & 1 & 20 & 292,22 & 21,29 & 120,00 & 480,00 \\
\hline & & & 2 & 21 & 299,18 & 31,43 & 90,00 & 720,00 \\
\hline & & & 3 & 20 & 279,25 & 24,80 & 166,67 & 540,00 \\
\hline & & & 4 & 9 & 388,89 & 77,45 & 160,00 & 780,00 \\
\hline & & & 1 & 26 & 348,86 & 40,28 & 120,00 & 1189,00 \\
\hline & & & 2 & 26 & 407,87 & 47,66 & 192,00 & 1472,50 \\
\hline & & & 3 & 25 & 368,19 & 56,25 & 120,00 & 1350,00 \\
\hline & & & 4 & 19 & 310,26 & 47,60 & 80,00 & 900,00 \\
\hline & \multirow{8}{*}{2} & & 1 & 23 & 223,68 & 21,32 & 92,80 & 568,67 \\
\hline & & FPp & 2 & 23 & 197,15 & 21,55 & 40,71 & 449,30 \\
\hline & & & 3 & 23 & 169,05 & 18,33 & 37,00 & 393,00 \\
\hline & & & 4 & 15 & 112,42 & 15,44 & 23,00 & 223,00 \\
\hline & & & 1 & 30 & 398,26 & 35,85 & 119,80 & 900,67 \\
\hline & & FS & 2 & 30 & 326,16 & 36,00 & 162,33 & 1050,00 \\
\hline & & & 3 & 30 & 415,59 & 37,96 & 165,08 & 1190,67 \\
\hline & & & 4 & 30 & 257,58 & 23,76 & 25,00 & 531,50 \\
\hline
\end{tabular}


Anexo IV: Médias descritivas dos dados de Distância em relação à mãe própria de todos os filhotes FS_1, FPp_1, FS_2 e FPp_2.

\begin{tabular}{|c|c|c|c|c|c|c|c|c|}
\hline Variável & Etapa & Condição & Semana & $n$ & Média & $\begin{array}{l}\text { Erro- } \\
\text { padrão }\end{array}$ & Mínimo & Máximo \\
\hline & \multirow{8}{*}{1} & \multirow{4}{*}{ FPp } & 1 & 21 & 0,498 & 0,090 & 0,000 & 1,340 \\
\hline & & & 2 & 21 & 0,287 & 0,048 & 0,010 & 0,870 \\
\hline & & & 3 & 21 & 0,317 & 0,057 & 0,010 & 1,030 \\
\hline & & & 4 & 21 & 0,326 & 0,046 & 0,060 & 0,950 \\
\hline & & \multirow{4}{*}{ FS } & 1 & 6 & 0,022 & 0,008 & 0,000 & 0,050 \\
\hline & & & 2 & 6 & 0,050 & 0,029 & 0,000 & 0,190 \\
\hline & & & 3 & 6 & 0,093 & 0,024 & 0,030 & 0,200 \\
\hline Distância & & & 4 & 6 & 0,168 & 0,082 & 0,000 & 0,520 \\
\hline Media da & \multirow{8}{*}{2} & \multirow{4}{*}{ FPp } & 1 & 23 & 0,348 & 0,040 & 0,130 & 1,000 \\
\hline Mãe & & & 2 & 23 & 0,368 & 0,037 & 0,060 & 0,740 \\
\hline \multirow[t]{6}{*}{ Própria } & & & 3 & 23 & 0,400 & 0,056 & 0,000 & 1,000 \\
\hline & & & 4 & 23 & 0,386 & 0,044 & 0,050 & 0,900 \\
\hline & & \multirow{4}{*}{ FS } & 1 & 30 & 0,069 & 0,016 & 0,000 & 0,310 \\
\hline & & & 2 & 30 & 0,110 & 0,016 & 0,000 & 0,300 \\
\hline & & & 3 & 30 & 0,121 & 0,017 & 0,000 & 0,350 \\
\hline & & & 4 & 30 & 0,242 & 0,024 & 0,070 & 0,630 \\
\hline
\end{tabular}

Anexo V: Ganho relativo de peso (peso final $\mathrm{g}$ - peso inicial $\mathrm{g} /$ peso inicial $\mathrm{g}$ ), dos filhotes FS_1, FPp_1, FS_2 e FPp_2, que mamaram pelo menos uma vez em cada semana.

\begin{tabular}{llrrrrr}
\hline Variável & Condição & \multicolumn{1}{l}{$\mathrm{n}$} & \multicolumn{1}{c}{ Média } & Erro-padrão & Mínimo & Máximo \\
\hline Aumento & FPp_1 & 18 & 148,37 & 9,37 & 82,61 & 250,00 \\
Relativo & FS_1 & 26 & 163,43 & 10,25 & 0,00 & 242,86 \\
de peso & FPp_2 & 23 & 200,62 & 9,20 & 114,06 & 303,57 \\
& FS_2 & 30 & 135,93 & 7,73 & 38,00 & 228,13 \\
\hline
\end{tabular}


Anexo VI: Médias descritivas dos dados de Freqüência Média de Amamentação e Aloamamentação dos grupos de filhotes FPp_1, FPp $(p+a)$ _1, Fpa(p+a)_1, FPp_2, $F P p(p+a) \_2, F p a(p+a) \_2$ que mamaram ao menos uma vez em cada semana.

\begin{tabular}{|c|c|c|c|c|c|c|c|c|}
\hline Variável & Etapa & Condição & Semana & $\mathrm{n}$ & Média & $\begin{array}{l}\text { Erro- } \\
\text { padrão }\end{array}$ & Mínimo & Máximo \\
\hline & 1 & FPp & 1 & 20 & 2,88 & 0,41 & 1,00 & 7,00 \\
\hline Freqüência & 1 & & 2 & 21 & 3,19 & 0,31 & 1,00 & 6,00 \\
\hline Mãe & 1 & & 3 & 20 & 2,65 & 0,35 & 0,50 & 6,00 \\
\hline \multirow{5}{*}{ Própria } & 1 & & 4 & 9 & 1,33 & 0,29 & 0,50 & 3,50 \\
\hline & 1 & $\operatorname{FPp}(p+a)$ & 1 & 23 & 1,96 & 0,17 & 0,50 & 3,50 \\
\hline & 1 & & 2 & 23 & 2,93 & 0,31 & 0,50 & 6,00 \\
\hline & 1 & & 3 & 22 & 1,84 & 0,20 & 0,50 & 4,00 \\
\hline & 1 & & 4 & 15 & 1,77 & 0,29 & 0,50 & 4,00 \\
\hline Freqüência & 1 & $F P a(p+a)$ & 1 & 21 & 0,76 & 0,10 & 0,50 & 2,00 \\
\hline \multirow[t]{3}{*}{ Mãe Alheia } & 1 & & 2 & 12 & 1,29 & 0,26 & 0,50 & 3,00 \\
\hline & 1 & & 3 & 8 & 1,19 & 0,38 & 0,50 & 3,50 \\
\hline & 1 & & 4 & 1 & 1,00 & - & 1,00 & 1,00 \\
\hline Freqüência & 1 & $F P(p+a)$ & 1 & 25 & 2,44 & 0,17 & 0,50 & 4,00 \\
\hline Própria+ & 1 & & 2 & 25 & 3,32 & 0,26 & 0,50 & 6,00 \\
\hline \multirow[t]{3}{*}{ Alheia } & 1 & & 3 & 24 & 2,08 & 0,19 & 0,50 & 4,00 \\
\hline & 1 & & 4 & 16 & 1,72 & 0,27 & 0,50 & 4,00 \\
\hline & 2 & FPp & $\overline{11}$ & 23 & 4,80 & 0,44 & 1,00 & 8,67 \\
\hline Freqüência & 2 & & 2 & 23 & 4,12 & 0,36 & 1,67 & 8,33 \\
\hline Mãe & 2 & & 3 & 23 & 3,19 & 0,63 & 0,33 & 14,00 \\
\hline \multirow[t]{5}{*}{ Própria } & 2 & & 4 & 15 & 3,10 & 0,91 & 0,25 & 11,00 \\
\hline & 2 & $F P p(p+a)$ & 1 & 40 & 4,13 & 0,22 & 1,67 & 7,50 \\
\hline & 2 & & 2 & 40 & 4,13 & 0,29 & 1,00 & 9,00 \\
\hline & 2 & & 3 & 40 & 3,86 & 0,38 & 0,67 & 10,67 \\
\hline & 2 & & 4 & 32 & 2,03 & 0,29 & 0,25 & 6,75 \\
\hline Freqüência & 2 & $\mathrm{FPa}(\mathrm{p}+\mathrm{a})$ & 1 & 35 & 1,07 & 0,16 & 0,25 & 4,00 \\
\hline \multirow[t]{3}{*}{ Mãe Alheia } & 2 & & 2 & 13 & 1,41 & 0,30 & 0,33 & 4,00 \\
\hline & 2 & & 3 & 10 & 0,87 & 0,19 & 0,33 & 2,00 \\
\hline & 2 & & 4 & 5 & 1,03 & 0,27 & 0,25 & 1,75 \\
\hline Freqüência & 2 & $F P(p+a)$ & 1 & 40 & 5,06 & 0,24 & 2,50 & 8,33 \\
\hline Própria+ & 2 & & 2 & 40 & 4,59 & 0,31 & 1,00 & 10,00 \\
\hline \multirow[t]{2}{*}{ Alheia } & 2 & & 3 & 40 & 4,08 & 0,40 & 0,67 & 10,67 \\
\hline & 2 & & 4 & 32 & 2,19 & 0,29 & 0,25 & 6,75 \\
\hline
\end{tabular}


Anexo VII: Médias descritivas dos dados de Duração Média Total de Amamentação e Aloamamentação dos filhotes FPp_1, FP(p+a)_1, FPp_2 e FP(p+a)_2, que mamaram pelo menos uma vez em cada semana.

\begin{tabular}{|c|c|c|c|c|c|c|c|c|}
\hline Variável & Etapa & Condição & Semana & $n$ & Média & $\begin{array}{r}\text { Erro- } \\
\text { padrão }\end{array}$ & Mínimo & Máximo \\
\hline & 1 & FPp & 1 & 20 & 835,50 & 125,60 & 120,00 & 2160,00 \\
\hline & 1 & & 2 & 21 & 884,29 & 100,35 & 90,00 & 2280,00 \\
\hline Duração & 1 & & 3 & 20 & 772,50 & 150,34 & 90,00 & 2460,00 \\
\hline Total - & 1 & & 4 & 9 & 493,33 & 122,79 & 150,00 & 1260,00 \\
\hline Mãe & 1 & $F P p(p+a)$ & 1 & 23 & 723,91 & 103,79 & 30,00 & 1740,00 \\
\hline \multirow[t]{3}{*}{ Própria } & 1 & & 2 & 23 & 1098,26 & 160,74 & 120,00 & 3540,00 \\
\hline & 1 & & 3 & 22 & 711,84 & 141,23 & 30,00 & 2760,00 \\
\hline & 1 & & 4 & 15 & 532,00 & 103,24 & 90,00 & 1260,00 \\
\hline Duração & 1 & $\mathrm{FPa}(\mathrm{p}+\mathrm{a})$ & 1 & 21 & 248,71 & 50,60 & 3,00 & 750,00 \\
\hline Total & 1 & & 2 & 12 & 485,00 & 130,97 & 30,00 & 1620,00 \\
\hline \multirow{2}{*}{$\begin{array}{l}\text { Mãe } \\
\text { Alheia }\end{array}$} & 1 & & 3 & 8 & 498,75 & 160,25 & 30,00 & 1320,00 \\
\hline & 1 & & 4 & 1 & 180,00 & - & 180,00 & 180,00 \\
\hline Dura & 1 & $\mathrm{FP}(\mathrm{p}$ & 1 & 25 & 874,92 & 125,61 & 60,00 & 2460,00 \\
\hline Tota & 1 & & 2 & 25 & 1243,20 & 150,71 & 150,00 & 3540,00 \\
\hline Própria+ & 1 & & 3 & 24 & 818,77 & 160,83 & 30,00 & 3240,00 \\
\hline \multirow[t]{3}{*}{ Alheia } & 1 & & 4 & 16 & 510,00 & 99,05 & 90,00 & 1260,00 \\
\hline & 2 & FPp & 1 & 23 & 993,20 & 91,25 & 184,33 & 2196,67 \\
\hline & 2 & & 2 & 23 & 766,94 & 81,70 & 142,50 & 1621,67 \\
\hline Duração & 2 & & 3 & 23 & 487,52 & 88,78 & 12,33 & 1422,00 \\
\hline Total - & 2 & & 4 & 15 & 371,59 & 116,45 & 11,25 & 1322,00 \\
\hline Mãe & 2 & $F P p(p+a)$ & 1 & 40 & 918,93 & 66,15 & 87,33 & 2015,33 \\
\hline \multirow[t]{3}{*}{ Própria } & 2 & & 2 & 40 & 777,72 & 55,18 & 220,00 & 1656,67 \\
\hline & 2 & & 3 & 40 & 576,38 & 57,78 & 13,00 & 1533,67 \\
\hline & 2 & & 4 & 32 & 321,23 & 53,80 & 8,50 & 971,00 \\
\hline Duração & 2 & $\mathrm{FPa}(\mathrm{p}+\mathrm{a})$ & 1 & 35 & 170,76 & 31,98 & 5,00 & 818,33 \\
\hline Total & 2 & & 2 & 13 & 255,87 & 55,72 & 8,33 & 666,00 \\
\hline \multirow{2}{*}{$\begin{array}{l}\text { Mãe } \\
\text { Alheia }\end{array}$} & 2 & & 3 & 10 & 109,57 & 45,01 & 3,67 & 434,00 \\
\hline & 2 & & 4 & 5 & 78,08 & 32,08 & 12,00 & 180,25 \\
\hline Duração & 2 & $F P(p+a)$ & 1 & 40 & 1068,35 & 63,39 & 131,33 & 2083,00 \\
\hline Total - & 2 & & 2 & 40 & 860,88 & 52,19 & 220,00 & 1665,00 \\
\hline Pró & 2 & & 3 & 40 & 603,77 & 57,14 & 13,00 & 1533,67 \\
\hline Alheia & 2 & & 4 & 32 & 333,43 & 52,94 & 8,50 & 971,00 \\
\hline
\end{tabular}


Anexo VIII: Médias descritivas dos dados de Duração Média por Episódio de Amamentação e Aloamamentação dos filhotes FPp_1, FP(p+a)_1, FPp_2 e FP(p+a)_2, que mamaram pelo menos uma vez em cada semana.

\begin{tabular}{|c|c|c|c|c|c|c|c|c|}
\hline Variável & Etapa & Condição & Semana & $n$ & Média & $\begin{array}{r}\text { Erro- } \\
\text { padrão }\end{array}$ & Minimo & Maximo \\
\hline & 1 & FPp & 1 & 20 & 292,22 & 21,29 & 120,00 & 480,00 \\
\hline & 1 & & 2 & 21 & 299,18 & 31,43 & 90,00 & 720,00 \\
\hline Duração & 1 & & 3 & 20 & 279,25 & 24,80 & 166,67 & 540,00 \\
\hline Episódio- & 1 & & 4 & 9 & 388,89 & 77,45 & 160,00 & 780,00 \\
\hline Mãe & 1 & $F P p(p+a)$ & 1 & 23 & 356,52 & 39,68 & 60,00 & 720,00 \\
\hline \multirow[t]{3}{*}{ Própria } & 1 & & 2 & 23 & 405,06 & 64,49 & 150,00 & 1680,00 \\
\hline & 1 & & 3 & 22 & 385,02 & 87,15 & 60,00 & 1920,00 \\
\hline & 1 & & 4 & 15 & 382,00 & 88,57 & 60,00 & 1320,00 \\
\hline Duração & 1 & $\mathrm{FPa}(\mathrm{p}+\mathrm{a})$ & 1 & 21 & 334,33 & 64,66 & 6,00 & 960,00 \\
\hline Episódio - & 1 & & 2 & 12 & 394,17 & 115,26 & 60,00 & 1620,00 \\
\hline Mãe & 1 & & 3 & 8 & 458,57 & 101,31 & 60,00 & 840,00 \\
\hline Alheia & 1 & & 4 & 1 & 180,00 & - & 180,00 & 180,00 \\
\hline Duração & 1 & $F P(p+a)$ & 1 & 25 & 343,20 & 37,96 & 75,00 & 768,00 \\
\hline Episódio - & 1 & & 2 & 25 & 390,09 & 56,40 & 150,00 & 1640,00 \\
\hline Própria + & 1 & & 3 & 24 & 343,21 & 54,30 & 60,00 & 1104,00 \\
\hline \multirow[t]{3}{*}{ Alheia } & 1 & & 4 & 16 & 369,38 & 83,80 & 60,00 & 1320,00 \\
\hline & 2 & $\overline{F P P p}$ & 1 & 23 & 223,68 & 21,32 & 92,80 & 568,67 \\
\hline & 2 & & 2 & 23 & 197,15 & 21,55 & 40,71 & 449,30 \\
\hline Dura & 2 & & 3 & 23 & 169,05 & 18,33 & 37,00 & 393,00 \\
\hline Episódio - & 2 & & 4 & 15 & 112,42 & 15,44 & 23,00 & 223,00 \\
\hline Mãe & 2 & $F P p(p+a)$ & 1 & 40 & 231,90 & 15,82 & 37,43 & 442,89 \\
\hline \multirow[t]{3}{*}{ Própria } & 2 & & 2 & 40 & 199,82 & 11,33 & 94,04 & 398,58 \\
\hline & 2 & & 3 & 40 & 157,74 & 10,08 & 19,50 & 275,20 \\
\hline & 2 & & 4 & 32 & 145,29 & 14,84 & 17,00 & 308,56 \\
\hline Duração & 2 & $F P a(p+a)$ & 1 & 35 & 152,60 & 18,23 & 10,00 & 398,00 \\
\hline Episódio - & 2 & & 2 & 13 & 206,21 & 51,47 & 22,00 & 648,00 \\
\hline Mãe & 2 & & 3 & 10 & 94,97 & 33,71 & 11,00 & 325,50 \\
\hline Alheia & 2 & & 4 & 5 & 73,87 & 28,14 & 26,50 & 180,25 \\
\hline Duração & 2 & $F P(p+a)$ & 1 & 40 & 218,80 & 13,23 & 49,25 & 425,80 \\
\hline Episódio & 2 & & 2 & 40 & 202,04 & 11,26 & 109,40 & 398,58 \\
\hline Própria+ & 2 & & 3 & 40 & 159,42 & 10,16 & 19,50 & 275,20 \\
\hline Alheia & 2 & & 4 & 32 & 140,48 & 14,61 & 17,00 & 308,56 \\
\hline
\end{tabular}

Anexo IX: Médias descritivas do ganho relativo do Peso - FPp x FP(p+a)

\begin{tabular}{llrrrrrr}
\hline Variável & Condição & $\mathrm{n}$ & Média & Mediana & Erro-padrão & Mínimo & Máximo \\
\hline Aumento & FPp_1 & 18 & 148,37 & 145,74 & 9,37 & 82,61 & 250,00 \\
Relativo & FP(p+a)_1 & 23 & 186,94 & 190,00 & 9,22 & 100,00 & 280,00 \\
\cline { 2 - 7 } Do peso & FPp_2 & 23 & 200,62 & 203,60 & 9,20 & 114,06 & 303,57 \\
& FP(p+a)_2 & 30 & 187,81 & 179,25 & 8,83 & 68,89 & 308,64 \\
\hline
\end{tabular}


Anexo X: Médias descritivas do Peso (g) na Etapa 2: FPp_2 x FS_2

\begin{tabular}{lccrrrrr}
\hline GRUPO & SEMANA & $\mathrm{n}$ & media & mediana & $\mathrm{se}$ & mínimo & máximo \\
\hline FPp2 & 1 & 23 & 91,09 & 93,00 & 3,68 & 56,00 & 119,00 \\
& 2 & 23 & 156,00 & 166,00 & 9,30 & 63,00 & 222,00 \\
& 3 & 23 & 214,35 & 235,00 & 11,53 & 101,00 & 275,00 \\
& 4 & 23 & 274,70 & 295,00 & 13,60 & 137,00 & 340,00 \\
\hline FS2 & 1 & 30 & 85,57 & 84,00 & 3,67 & 50,00 & 125,00 \\
& 2 & 30 & 143,07 & 143,00 & 7,23 & 67,00 & 205,00 \\
& 3 & 30 & 171,13 & 169,00 & 10,07 & 75,00 & 292,00 \\
& 4 & 30 & 203,70 & 202,00 & 11,45 & 69,00 & 328,00 \\
\hline
\end{tabular}

Anexo XI: Médias descritivas do Peso (g) na Etapa 2: FP(p+a)_2 x FSp_2

\begin{tabular}{lccrrrr}
\hline GRUPO & SEMANA & $\mathrm{n}$ & media & $\mathrm{se}$ & mínimo & Máximo \\
\hline $\mathrm{FP}(\mathrm{p}+\mathrm{a}) \_2$ & 1 & 40 & 91,40 & 2,33 & 60,00 & 114,00 \\
& 2 & 40 & 155,35 & 5,15 & 94,00 & 210,00 \\
& 3 & 40 & 204,18 & 7,01 & 124,00 & 268,00 \\
& 4 & 40 & 261,40 & 9,18 & 152,00 & 374,00 \\
\hline FPp_2 & 1 & 23 & 91,09 & 3,68 & 56,00 & 119,00 \\
& 2 & 23 & 156,00 & 9,30 & 63,00 & 222,00 \\
& 3 & 23 & 214,35 & 11,53 & 101,00 & 275,00 \\
& 4 & 23 & 274,70 & 13,60 & 137,00 & 340,00 \\
\hline
\end{tabular}

